University of Rhode Island

DigitalCommons@URI

Open Access Dissertations

2020

\title{
"THE SKIPPING KING”: MASCULINITY AND EFFEMINACY IN EARLY MODERN DRAMA
}

Danielle Johanna Sanfilippo

University of Rhode Island, dsanfilippo@my.uri.edu

Follow this and additional works at: https://digitalcommons.uri.edu/oa_diss

\section{Recommended Citation}

Sanfilippo, Danielle Johanna, "'THE SKIPPING KING": MASCULINITY AND EFFEMINACY IN EARLY MODERN DRAMA" (2020). Open Access Dissertations. Paper 1166.

https://digitalcommons.uri.edu/oa_diss/1166

This Dissertation is brought to you for free and open access by DigitalCommons@URI. It has been accepted for inclusion in Open Access Dissertations by an authorized administrator of DigitalCommons@URI. For more information, please contact digitalcommons-group@uri.edu. 
“THE SKIPPING KING”: MASCULINITY AND EFFEMINACY IN EARLY MODERN DRAMA

BY

DANIELLE JOHANNA SANFILIPPO

A DISSERTATION SUBMITTED IN PARTIAL FULFILLMENT OF THE

REQUIREMENTS FOR THE DEGREE OF

DOCTOR OF PHILOSOPHY

IN

ENGLISH

UNIVERSITY OF RHODE ISLAND 
DOCTOR OF PHILOSOPHY DISSERTATION

OF

DANIELLE JOHANNA SANFILIPPO

APPROVED:

Dissertation Committee:

Major Professor Travis Williams

Jean Walton

Rachel Walshe

Nasser H. Zawia

DEAN OF THE GRADUATE SCHOOL

UNIVERSITY OF RHODE ISLAND

2020 


\begin{abstract}
This dissertation analyzes depictions of effeminacy and anxiety surrounding masculinity in early modern drama. Effeminacy is a frequently used term in the literature of the period, occurring seven times in Shakespeare alone. For my research, I combine literary analysis and performance criticism. I consulted the National Theatre Archives in London and the Shakespeare Birthplace Trust in Stratford to analyze performances of early modern plays. Effeminacy is a wide-reaching mode of being that makes several layers of meaning. For royals and men of rank, the presumption of effeminacy is a danger to the realm. In Roman historical drama, effeminacy stands in for the decay of the state of Rome, as well as offering implications for the early modern era in which the plays were written. But for youths and in comedy, effeminacy can be an anxiety-provoking but not always harmful phase that leads men from immaturity to maturity. Chapter One analyzes early modern conduct books in conjunction with Sir Philip Sidney's The Old Arcadia. This chapter provides an overview of the standards of masculine behavior expected for noblemen. Chapter Two moves to a discussion of Renaissance appropriations of Roman history, with an analysis of William Shakespeare's Antony and Cleopatra and Ben Jonson's Sejanus His Fall. It builds on the discussion of gender expectations. Chapter Three continues the evaluation of historical drama by examining two English history plays, Shakespeare's Richard II and Christopher Marlowe's Edward II. By analyzing two English kings often described as effeminate, I interrogate the role of effeminacy in Renaissance audiences' relationship to the monarchy. Finally, I consider what happens
\end{abstract}


when effeminacy is played for laughs. In Chapter Four, I discuss two Shakespearean comedies, Love's Labour's Lost and As You Like It. I analyze the subjugation and humiliation of the male characters in these plays and discover how effeminacy can play a role in shaping adult male sexuality. 


\section{Acknowledgments}

First, I would like to my thank my major professor, Dr. Travis Williams. Dr. Williams has been a wonderful source of scholarly mentorship and support throughout my eight years at the University of Rhode Island. I am especially grateful for his support in my decision to take a year of medical leave rather than struggling through immense pain to finish my dissertation. He stayed in contact with me and provided support on campus as I went through multiple hospitalizations and surgeries. His feedback on this project has been invaluable and my writing has become much sharper and clearer through his guidance. His presence and support helped me achieve the dream of a lifetime.

I would also like to thank my committee members; Jean Walton, Rachel Walshe, Catherine Sama, and Carolyn Betensky for their scholarship and support as I finish this project. I am grateful for their feedback and kind words as I moved from exams to prospectus to dissertation defense.

Michelle Caraccia provided emotional support and clarity for me when deadlines became confusing and overwhelming. She eagerly waited for news when I got out of surgery and welcomed me back to campus with warm hugs. Michelle saw me through triumphs and tough times and gave me strength to continue my journey. She will be missed, and I wish her a very happy retirement.

I would like to thank URI's Center for the Humanities for their generous support for this project. A Graduate Research Grant allowed me to visit London and Stratford to collect valuable archival evidence. Many thanks. 
I would like to acknowledge the generous and knowledgeable staff at the National Archives, London, and the Shakespeare Birthplace Trust, Stratford. You made a chilly January research trip into a highlight of the year. You found newspaper clippings, video footage, and even costume samples for me to consult. Thank you for your kind assistance.

Sarah Enloe, Educational Director at the Blackfriars Playhouse, assisted me through several trips to the Blackfriars Conference. She also put me in touch with the fantastic Sarah Fallon for an interview. Thank you, Sarah Enloe, and I look forward to seeing you again at the next conference! Thank you again to Sarah Fallon for chatting with me and providing me with so many insights into playing Richard II and Cleopatra. Seeing you play Richard from a gallant stool on the Blackfriars stage was a theatrical experience that will stay with me forever.

Thank you to my peers in the Graduate Writing Group, especially our organizer, Molly Hall. Your support and encouragement have been invaluable. I have loved reading your work and it has been so heartening to hear your comments on mine.

Thank you to my grandmother, Josephine Sanfilippo, who helped raise me and has provided financial support throughout my doctorate. I'm so happy to make you proud by finally becoming a doctor. I love you, Nonna.

Many, many thanks to my wonderful parents, Gerlando and Cheryl Sanfilippo, for their endless support. You have provided financial support for my academic career, and you have been my cheerleaders at almost every conference I have attended. Last year, you nursed me through a lengthy operation so that I could finish my degree 
strong and healthy. I am always mindful of the sacrifices you made so that I could attend Mount Holyoke, and later Boston College. You have read countless papers and sat through many talks. I can't wait to see you cheering me on at my defense. All my love, always.

Finally, this section would not be complete without warm thanks to my beloved wife, Allison Krebs. I have lost track of the hours you have spent listening to me babble about performance, gender theory, and effeminacy. Through our conversations on these topics, I have become a much better scholar. You have read these chapters as they have emerged from my brain and given me your kind thoughts. Just as you promised on our wedding day, you have supported me generously and unselfishly as I have walked this difficult road. You have cleaned, dropped off laundry, and cooked for me. When I needed a distraction, you were right there with recommendations for Star Wars fanfiction or a movie night. You have hugged me and dried my tears when I thought I couldn't do it. I love you so much and I can't wait to start our next chapter! 


\section{Dedication}

This dissertation is dedicated to Tom Hiddleston. Several years ago, I saw you as Prince Hal in The Hollow Crown. Watching you with Jeremy Irons in the scene which gives this dissertation its title, "The Skipping King," I knew that my work would be incomplete without substantial performance analysis. The conflict between father and son, and the ghost of Richard's effeminacy, became clear to me in a new way. In this project, I have tried to honor the performances from you and many other gifted actors with focused scholarship. That episode of The Hollow Crown has stayed with me through the years, whether as an inspiration for a new conference paper or a comfort when recovering from surgery. It has kept me going through this massive and often overwhelming project. Thank you, Tom Hiddleston, for helping me realize that "I am burdened with glorious purpose." 


\section{Table of Contents}

Abstract...............................................................

Acknowledgments..................................................iv

Dedication........................................................ vi

Table of Contents....................................................... viii

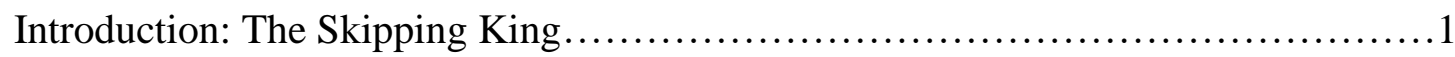

Chapter 1: A Pastoral Excursion: Courtiers and Sidney’s The Old Arcadia............15

Chapter 2: Classical Precedents: Roman Gender and Sexuality in Sejanus His Fall and Antony and Cleopatra.....................................40

Chapter 3: Skipping Kings and Minions: Reading Edward II and Richard II.........74

Chapter 4: Masculinity and Painful Subjugation in Comedy: Love's Labour's

Lost and As You Like It............................................ 110

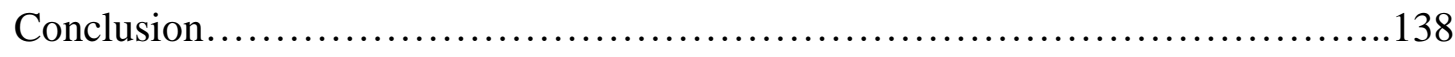

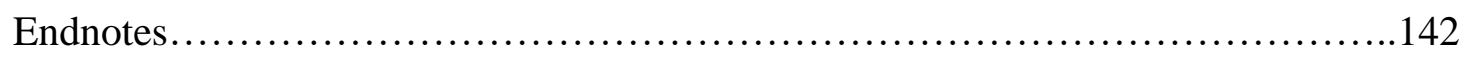

Works Cited......................................................... 144 


\section{Introduction: The Skipping King}

The title for this dissertation is taken from a long speech in Shakespeare's 1 Henry IV that has always followed me. I was struck by the venom with which I had seen an actor spit out the words and they stuck on the page as well. The line encapsulated the problems with masculinity that I outline in this study. King Henry has summoned his son, Prince Hal, to lecture him on his recent behavior and the low company he keeps. In the middle of this paternal lecture, the king compares his son unfavorably with the late Richard II, whom King Henry deposed. Richard's name is not even mentioned for many lines; instead, he is referred to as "the skipping king” (3.2.60). Henry's chief complaint against his royal cousin mirrors his current problem with Hal; Richard kept bad company and did not behave correctly.

The skipping king, he ambled up and down With shallow jesters and rash bavin wits, Soon kindled and soon burnt; carded his state; Mingled his royalty with cap'ring fools; Had his great name profaned with their scorns And gave his countenance, against his name, To laugh at gibing boys and stand the push Of every beardless vain comparative; Grew a companion to the common streets, Enfeoffed himself to popularity; That, being daily swallowed by men's eyes, They surfeited with honey and began To loathe the taste of sweetness, whereof a little More than a little is by much too much... And in that very line, Harry, standest thou; For thou hast lost thy princely privilege With vile participation. (60-87)

King Henry is careful to contrast Richard's constant presence with his own. As he reminds his son, "By being seldom seen, I could not stir / But, like a comet, I was wondered at; / That men would tell their children, 'This is he!' / Others would say, 
"Where? Which is Bolingbroke"' (3.2.46-49). The distinction is clear; the former

Bolingbroke's behavior was truly majestic; he is a comet, a wonder from heaven. Richard is merely a skipping king.

The use of the term "skipping" as an adjective dates back to the 1560 s, according to the Oxford English Dictionary. It cites this scene as one of the earliest uses of the term in this sense. The king certainly means it to be slighting. In performance, actors generally give emphasis to the word. But why a skipping king, and what is wrong with skipping?

The term is meant to cast Richard in a childish light, leaving the audience to imagine him playing children's skipping games or perhaps dancing excitedly. The speech goes on to describe the kinds of people that the late king associated with. There are shallow jesters, rash bavin wits, or people of low intelligence whose wit is burned up with one amusing anecdote, gibing boys, which suggests a familiarity with less masculine individuals, and finally, beardless vain comparatives. The fact that they are beardless is another indication of unripe masculinity. Besides associating with these unsavory types, Richard committed the cardinal sin for a monarch; he made himself too popular. Indeed, he "enfeoffed himself to popularity." The term "enfeoff” originally meant to invest someone with a parcel of land. By Shakespeare's day, a figurative meaning emerged; to surrender. By using a formerly feudal term, King Henry reveals the irony inherent in Richard's case; he should have "enfeoffed" in the traditional sense, but he lost so much power that he could only surrender his body. The king ends his speech by reminding Hal of the danger that he is in; majesty is a privilege. The is especially true for King Henry, who came to the throne by force. The family grip on the throne could be lost just as easily as Richard lost his kingship. 
This scene is incredibly powerful in performance. An excellent example can be found in the BBC's The Hollow Crown with Jeremy Irons as King Henry and Tom Hiddleston as Prince Hal. Hiddleston enters wearing a burgundy jerkin and a red hat, in contrast to the black clothing worn by the rest of the court. As his father proceeds through his long lecture, Hiddleston sighs and rolls his eyes, prompting the king to angrily seize his red hat and throw it on the floor in disgust. As the king pauses for breath, Hiddleston promises to be more himself with a smirk. Irons retorts by slapping his son harshly across the face. As a red mark spreads across his cheek, Hiddleston chokes back tears and vows to defeat Hotspur and the rebels. The king's reaction at the end of the scene proves that Hal had finally put on a performance of masculinity that his father could be proud of and that he was moving away from the picture of an effeminate prince that his father had previously assumed him to be. Hal's rank is crucial here: while a man of lower rank might engage in similar behavior and be labelled a wastrel, a prince engaged in these pursuits displays a want of masculine qualities that mark him as effeminiate.

Throughout Henry's rich speech, the king hints at, but does not fully express what Richard's difficulty really was. It is true that he did not behave like a king, but the specific problem that Bolingbroke had with his cousin was the former's lack of proper masculinity. Richard was not behaving according to Bolingbroke's standards of masculinity, let alone kingship. In other words, Richard struggled with a perceived tendency toward effeminacy.

\section{Why Effeminacy?}

This study surveys the presence, or the assumed presence of effeminacy in aristocratic male characters in early modern literature. To define this term clearly, in the 
Oxford English Dictionary, "effeminacy" is defined as "Effeminate quality; unmanly weakness, softness, or delicacy" (OED online) and first appears in the English language in 1602 in a history of England. "Effeminate" is defined as "Womanish, unmanly, feeble; self-indulgent, voluptuous; unbecomingly delicate or overly refined" (OED online). This usage dates from 1430, before the early modern era. The dictionary definition conveys a sense of the word, but it is woefully incomplete in addressing deeper implications. This definition ignores one of the most important aspects of effeminacy that appears frequently when the word is used in early modern texts: men being controlled by women. When Antony leaves a sea battle to follow his lover in Antony and Cleopatra, it is this aspect of effeminacy that underlines his actions. Effeminacy need not only apply to humans; it can also be used to describe situations. The aggressive English in 1 Henry VI object to being forced into an "effeminate peace" (5.4.107). This phrase conveys a gendered meaning of an abstract idea. Peace, by its absence of hostility, is figured as unbecomingly womanish. Effeminacy, then, is not merely the image of a delicate, overly refined man, but a framework for describing behavior, people, or situations that address the absence or imperfect performance of, masculinity. These are preliminary definitions of effeminacy and it is the goal of this study to refine, expand, complicate, and interrogate these definitions.

Some scholars may be uncomfortable with "effeminacy" because it is perceived to be a misogynistic term. However, while the term frequently insults men by comparing them to women, it is a word with a long history that was in contemporary use in the works I discuss. While our own attitudes toward the past will always be colored with a modern perspective, we need not skip over important avenues of research. The word 
effeminacy has greatly shrunk in popularity over the centuries; accordingly, the word has been underused in literary criticism. Recent examples of its usage include Effeminacy, Masculinity, and Homosocial Bonds: The Victorian Construction of John Keats by Caroline Kimberly (2006), and Performing Masculinity: Control, Manhood and the Rhetoric of Effeminacy by Lindsay Green McManus (2007). The latter work does consider the masculinity of early modern courtiers, but it is primarily a work of gender studies, not literary criticism. Effeminacy is discussed in early modern studies as it relates to masculine norms. Authors such as Alan Sinfield and Anthony Fletcher have used the term in relation to early modern masculinity. Historical discussions of effeminacy date back at least as far as Roman author Quintilian's Institutio Oratoria. Quintilian provides examples of orators whose style he disapproves of based on behavior that he terms effeminate. In Book 8, Chapter 3, when discussing how an orator might groom himself, Quintilian states, "But such ornament must, as I have already said, be bold, manly, and chaste, free from effeminate smoothness and the false hues derived from artificial dyes" (Quintilian, Institutio Oratoria web). The anti-theatrical movement of the late Elizabethan era, with writers including John Rainoldes, and William Prynne, were also deeply concerned with effeminacy. Rainoldes rails against the effeminacy of the stage actor: "that an effeminate stage-player, while he faineth love, imprinteth words of love" (qtd. in Orgel 28). In other words, the effeminacy of the actors will imprint lustful feelings, followed by more effeminate behavior, on his listeners. Prynne was disgusted by the transvestism of the stage, while Philip Stubbes worried about lewd behavior that the atmosphere of the theater might encourage, leading to his famous assertion that after theatrical performances, the audience members "play the sodomites 
or worse" (qtd. in Orgel 29). For Stephen Orgel, the wealth of anti-theatrical literature indicates one profound anxiety: "the deepest fear in the antitheatrical tracts, far deeper than the fear that women in the audience will become whores, is the fear of a universal effeminization" (29). Following the anxiety identified by Orgel, this study synthesizes literary and historical discussions of effeminacy to better understand its presence in early modern literature.

To return to the dictionary definition of effeminacy, the terms are contemporary with the period I am discussing and therefore, effeminacy/effeminate are appropriate terms to discuss masculine behavior that other characters find fault with. The word effeminate appears seven times in Shakespeare's plays, twice in 1 Henry VI alone. I maintain that by studying the term effeminacy we can gain an insight into male-male power dynamics and power struggles in the early modern period. Furthermore, while the term effeminacy may imply violation of certain societal norms, it does not imply that a man described as effeminate is engaging in deviant sexual behavior (by early modern standards).

\section{Sexuality, or, Top/Bottom}

Though I intend to clearly separate sexual from nonsexual behavior in my analysis, sexuality remains important, particularly in my discussions of Antony and Cleopatra, Sejanus, and Edward II. Because sexuality was understood quite differently in the early modern period, modern attempts to analyze sexuality in these works can be a difficult endeavor. Alan Bray discusses the cases of several men who were prosecuted for sodomy (43). In each case, the man in question was convicted of having had sexual 
relations with another man or boy. Though the legal definition of sodomy was vague, certain behaviors could be prosecuted in a court of law. Meanwhile, a man could not be prosecuted simply for experiencing desire for another man. Several of the characters in my study may experience male-male desire. While the modern era tends to classify such men as either homosexual or bisexual, in the early modern era, desire did not define sexuality. Sexuality was understood quite differently from gender. The categories of homosexual and heterosexual did not yet exist, and while men could be prosecuted for sodomy, as Bray's accounts testify, the term "sodomy" did not apply only to male-male sexual relations. "Homosexuality", "lesbianism" and similar terms are modern constructions. Bray, Traub, and others are unable to keep such terms out of their analysis, primarily because our language does not have the nuance to capture historical difference. Using the term effeminacy instead avoids using these terms when they are inappropriate. I also follow Bruce Smith's lead in using the terms top and bottom to indicate two characters in a relationship where there is an imbalance of power, not as the largely sexual terminology they constitute today. While certain characters might express a fear of "bottoming" in a sexual sense (this will be particularly important in my discussion of Marlowe's Edward II), this study remains largely focused on what happens when an aristocratic man takes a lesser role in a power exchange.

\section{Performance Study and Presentism}

My study of early modern literary texts is underpinned by presentist and performance theory as well as gender and queer studies frameworks. Since all but one of the works in this study are dramatic works, and since the early performances of dramatic texts were hotly contested by the anti-theatrical movement, it is necessary to analyze 
what performance can illuminate in the text. I utilize performance criticism to underscore the importance of live performance in my work and to develop an understanding of how aristocratic male characters' behavior functions in their society. I have primarily consulted Erving Goffman's The Presentation of Self in Everyday Life to analyze how dramatic characters perform different aspects of themselves. Presentism is a relatively new trend in early modern studies, with major proponents including Hugh Grady, Terence Hawkes, and James O’Rourke. As Hugh Grady states, “...there can be no historicism without a latent presentism. The past continually changes its shape and meaning for us as we move further into the future...our attitude towards the past governs our approach to the artefacts of that past" (142). Grady is analyzing how changing aesthetic paradigms have changed how Hamlet has been perceived over several centuries. Presentism acknowledges our viewpoint when observing the past and crates more aware scholarship. The theory is also particularly useful when incorporating modern gender and queer theory, as Evelyn Gajowski demonstrates in her work on Lavinia as a rape survivor. ${ }^{i}$ Utilizing a presentist framework allows me to look at both my primary texts and secondary texts such as works by performance theorist Erving Goffman with a new awareness of my own place as a present-day scholar. My presentist approach considers how our place as present-day scholars influences our outlook on the past and how the past continues to shape our experience of the present. Presentism also provides a useful model for studying performance. James O'Rourke considers three Shakespearean comedies and uses popular productions in order to understand how certain textual moments are changed since we have moved away from the early modern transvestite stage. ${ }^{\text {ii }}$ My use of live performance in this dissertation intersects with 
presentist thought as I consider how performance of early modern texts perpetuates portrayals of traditional masculinity and seeks to shift in the narrative toward a more nuanced interpretation of masculine behavior and desire. Furthermore, presentism has been utilized primarily with Shakespeare. Incorporating the theory into my survey of Shakespeare, Jonson, Marlowe and Sidney allows me to make a critical intervention in the field.

To provide an example of presentism in action, I would like to introduce the case of Shakespeare's 1 Henry VI. The opening play of a trilogy, this play (under the title Shakespeare's Joan of Arc), was performed in October 2015 by the American Shakespeare Company in Staunton Virginia. The performance was part of the biannual Blackfriars Conference. The Company utilizes period conditions whenever possible and their performances are staged in a recreation of Shakespeare's indoor theatre at Blackfriars. The theatre is illuminated by large chandeliers, which allows the audience to observe each other as well as the actors. In staging I Henry VI, the company cast Stephanie Earl Holladay in the role of the young king. Other roles in the text were played by actors of the corresponding gender, with a few exceptions. The decision to cast a woman as the king was bound to be controversial; the dismay coming from some audience members in the stalls was palpable. Other audience members thought they knew what was intended; the presence of a woman signified a weak king. This was a question that arose in talkbacks; the actors, particularly Holladay herself, quickly shot down this notion. When I discussed the play with my conference panel on literary criticism as performance the next morning, we had rather a different view. Holladay had skillfully shown us not a king who was secretly a woman, or a king whose weakness 
marked him as feminine, but a king who was profoundly uncomfortable with the standard of masculinity that was expected of him. The other actors, notably Rene Thornton's Duke of Gloucester, demonstrated a toxic masculinity that rapidly leads to bloodshed. Holladay's King Henry was desperately seeking a different paradigm. Shakespeare gives us a young king who is torn between the need to protect his father's legacy and his desire for peace. Holladay gave audiences a new way of looking at this frequently overlooked king.

Every audience member who engaged in discussion was performing his or her own presentist criticism. Our views were all inevitably colored by certain factors, such as age, gender, scholarly training, and other critical viewpoints that we espouse.

Throughout this dissertation, I have remained mindful of my own position and the fact that the past will never fully unfold its secrets. What presentism offers, however, is the chance to use modern performance to confirm what I have uncovered through close reading. For this reason, this study contains much theatrical as well as literary analysis. For plays that I have not been able to attend a live performance of, such as Sejanus and Edward II, I relied on video recordings of performances by the Royal Shakespeare Company as well as televised Shakespearean productions such as the BBC's The Hollow Crown.

A final major source of analysis for this dissertation is early modern conduct books. To understand the standards of masculine behavior that early modern English society required, I have also used conduct books of the period as primary sources. These will include Thomas Elyot's Book of the Governor (1531) and Castiglione's The Courtier (1528), an Italian example of the genre translated into English and widely popular 
among aspiring courtiers. Conduct books had many goals; some focused on

admonishing men to refrain from vices such as drinking and gambling, while others focused on instruction in the qualities needed for leadership and to inspire respect. Thus, they provide a complete picture of advice and standards for behavior directed at young men.

\section{A Chapter Survey}

I begin my dissertation in chronological order, with a study of Sir Phillip Sidney's The Old Arcadia. Sir Phillip Sidney's work is often treated as tragicomedy due to the contrasting nature of many of its themes, including sexual pleasure and violent death. The dramatic aspects of the work are of interest to this study. Sidney chooses to divide his work into acts, rather than chapters and the structure and plot of the work is in keeping with Sidney's interest in the emerging genre of English drama expressed in his Defense of Poesy. I investigate how Sidney utilizes the framework of masculine behavior in this blended genre. In many respects, the princes Pyrocles and Musidorus of The Old Arcadia exemplify the tropes of effeminacy that I discuss throughout the project. They share a common trait with Edward II among others of avoiding the responsibilities of state for the pleasures of love. The romantic relationships in Sidney's work are as tangled as those in Shakespeare's comedies, with standards for proper masculinity at the center of it all. The first chapter is intended to represent the standards of proper actions, thought, and speech for aspiring noblemen before discussing how the characters in the following chapters have held themselves to these standards or fallen drastically short.

Following my discussion of Sidney, I move on to two of Shakespeare and Jonson's Roman plays, Antony and Cleopatra and Sejanus. This chapter explores early modern 
authors Shakespeare and Jonson's concern with ancient Roman masculinity. To properly analyze these works, I consulted the playwrights' sources, including the ancient historians Tacitus, Plutarch and Suetonius. Tacitus covers the reign of the Emperor Tiberius and Sejanus' rise to power while Suetonius offers portraits of the emperor with frequent assessment of his masculinity. Plutarch, meanwhile, gives a full account of the life and character of Mark Antony, particularly his association with Cleopatra. My research into ancient history is necessary methodologically because early modern standards of masculinity were quite different from Roman standards. It is useful to remember that authors such as Shakespeare and Jonson interpreted and appropriated concepts of Roman masculinity for their own purposes. Furthermore, the two authors have very different viewpoints toward their classical sources that are reflected in their depiction of their male leads. Therefore, it is necessary to go back to the classical era in order to try at separating historical fact from a playwright's fiction, while keeping in mind that classical historians also had their own biases. I endeavored to locate early modern historical perspectives on these figures. Of the four chapters of this project, Chapter 2 focuses the most on sexuality. The characters of Antony, Sejanus, and Tiberius are all controlled by their own sexuality. The case of Antony and his obsession with Cleopatra is the most famous, but Jonson's play offers Sejanus' deadly ambition for Livia's love and the Emperor Tiberius' legendary sexual excesses.

My research into the genre of historical drama continues with an analysis of Shakespeare's Richard II and Marlowe's Edward II. In this chapter, I explore Shakespeare and Marlowe's reading of two medieval English kings who have been frequently described as effeminate, Edward II and Richard II. Edward and Richard are 
both found wanting in displays of masculinity by those around them. Edward's death is particularly gruesome and physically humiliating in its determination to fix an image of deviant sexual behavior in the minds of the audience. Edward's sexual behavior is questioned by his noblemen, but their main concern is that his lover is a foreigner of lower birth. In other words, top and bottom dynamics are heavily present in this play. In the end, what is truly being questioned is not necessarily the king's sexuality but the dynamics of rank in interpersonal relationships. Richard's case is a far subtler one, though he too is slighted for not being properly masculine. His cousin and usurper Bolingbroke describes him in slighting terms. In what specific ways do Edward and Richard transgress the boundaries of masculinity and are these failures sexually based at all?

Finally, I examine the gender politics of comedy in Shakespeare's As You Like It and Love's Labor's Lost. I analyze how the treatment of masculinity differs when presented in a comic light while developing the pastoral genre introduced in Chapter 1. The aristocratic male characters in these comedies put themselves through various trials for love. These include Orlando's mock wooing of Ganymede in As You Like It (though Orlando is a special case since his elder brother and guardian has failed to instruct him in the manners of the aristocracy) and the trial of celibacy that the King of Navarre and his lords are forced to undergo at the end of Love's Labour's Lost. My research examines the nature of masculine desire, possibilities for homoeroticism and the various methods of subjugation the characters go through.

In my conclusion, I revisit ideals of masculinity and the implications of my research for the combined fields of early modern literature and gender studies. By 
examining the history of masculinity and effeminacy and their relationship to power in the early modern era and assessing the presence of both in literature, this research responds to a gap in the conversation about how we view the aristocratic male characters of authors like Shakespeare, Jonson, Marlowe, and Sidney. It is important to address the danger of strict gender expectations for men as well as women. Whether through moments that are tragic, comedic, or somewhere in between, these characters reveal a struggle to maintain standards of masculinity and to avoid the specter of effeminacy. 


\section{Chapter 1: A Pastoral Excursion: Courtiers and Sidney's The Old Arcadia}

How did noblemen in the early modern era go about the business of being a courtier? What resources were available for them to learn the standards of thought, speech, and behavior expected of them? How were the boundaries of masculinity defined and what were the consequences of transgressing those boundaries? When are behaviors defined as effeminate? Finally, what were noblemen asked to do with ungovernable emotions? In this chapter, I will discuss how patterns of success were laid for aspiring noblemen and how they were instructed to avoid effeminate behavior. My literary text is Sir Phillip Sidney's The Old Arcadia. I have chosen to use this text rather than the revised New Arcadia because of the dynamic between the two princes, especially Musidorus' complicity in his cousin's cross-dressing plan. Whereas in the New Arcadia, Musidorus encounters his cousin after he has put on the Amazon attire, in Sidney's original text, Musidorus dresses Pyrocles as Cleophila, making him complicit in the effeminization of Pyrocles. Sidney, a courtier himself during the reign of Elizabeth, completed his work in $1580 .{ }^{\text {iii }}$ His tale concerns two young princes, Pyrocles and Musidorus, who despite their strong character cannot avoid the pitfalls of romantic love. Sidney's glimpses into the psyche of the two princes are framed by the profusion of conduct literature current at the time. I will address two famous examples, Baldassare Castiglione's The Courtier, and Sir Thomas Elyot's The Book of the Governor. The writers of these conduct books lay the groundwork for establishing the accepted parameters for courtly behavior. Sidney's tale upholds these social norms for the most part, but his heroes diverge from them in fascinating ways. Since Arcadia is a text with a convoluted plot, a short synopsis will be helpful for understanding my later discussion. I 
will then open with an example of effeminacy in action from Arcadia to introduce the conduct books before ending with a close reading of the early sections of Arcadia. This chapter addresses the questions of what constitutes acceptable English masculinity and "othered" effeminacy before investigating what occurs when men cannot live up to the standards that are set for them. In this chapter, I lay the groundwork for my theatrical study by analyzing popular prose works that predate the explosion of theatrical culture. I argue that effeminacy is presented as both a danger to be avoided at all costs, and a common experience on the road to mature masculinity.

\section{Arcadia Synopsis}

Arcadia opens with the Duke of Arcadia, Basilius, facing a dilemma. He receives an alarming message from the Oracle of Delphi revealing that within the year his older daughter will be abducted, while his younger daughter will embrace an unnatural love. Baffled and frightened, the Duke gives up his responsibilities of state to live in seclusion with his family. Meanwhile, two young princes, Pyrocles, and Musidorus, enter the land of Arcadia. Pyrocles immediately falls in love with Philoclea upon seeing her portrait. $\mathrm{He}$ convinces Musidorus to help him cross-dress as an Amazon and takes on the identity of Cleophila. Cleophila's ruse is successful and "she" wins the affections of not only Philoclea, but of both of her parents. Musidorus falls in love with the older daughter, Pamela, and disguises himself as a shepherd named Dorus to court her. The young princes have succeeded in winning the hearts of the princesses. Cleophila reveals himself to be Pyrocles and consummates his relationship with Philoclea. Musidorus convinces Pamela to elope with him, and though he initially pressures her for sexual activity, he changes his mind. One misdirected love potion, heavy sleep mistaken for death, and a 
trial later, all is well. The princes are forgiven for their youthful indiscretions and their marriages are properly celebrated.

\section{Proper Conduct}

To begin, I will discuss a short passage near the beginning of Arcadia that touches on issues of proper conduct for young men. Pyrocles, the younger of the two princes, has just listened to his cousin lecture him on the distinction between the pure love of virtue and the effeminate love of a woman and the dangers of allowing oneself to be subjugated by a woman. I will discuss this lecture at length further on.

Pyrocles' mind was all this while so fixed upon another devotion that he no more attentively marked his friend's discourse than the child that hath leave to play marks the last part of his lesson, or the diligent pilot in a dangerous tempest doth attend to the unskilful words of the passenger. Yet, the very sound having left the general points of his speech in his mind, the respect he bare to his friend brought forth his answer, having first paid up his late-accustomed tribute of sighs. (19)

Pyrocles' is so absorbed in the new and interesting emotion of love that he is not paying attention to his friend. In a fascinating turn, Sidney describes his inattention as both positive and negative. Pyrocles is at once like a small child neglecting the end of his lessons because it is almost playtime. This image reinforces Pyrocles' youth and gives the reader the impression that he is not yet mature enough to understand the necessity of the argument that Musidorus is trying to make. However, Pyrocles is also like an experienced sailor who ignores the unproductive words of a passenger because he does not know what he is talking about. This image undercuts the previous metaphor and indicates that perhaps Musidorus' speech is full of wise advice, but he too does not know what he is talking about. Pyrocles absorbs the speech seemingly by osmosis, but crucially, he respects his friend and elder cousin, so he formulates a clear response. The young prince is demonstrating an essential quality for a young nobleman; respect for an elder, and he 
attempts to use his wit and understanding to debate with Musidorus. His tribute of sighs is a sly nod to the sighing dramatics of the adolescent, a category that Pyrocles falls firmly into. In this excerpt, Pyrocles is displaying a kind of effeminacy; the effeminacy associated with youth. He has not yet attained the qualities of a proper man, but he is slowly developing them, as his respectful debate and behavior over the course of the text will demonstrate. Pyrocles is behaving like a youth who has read all the important books but has not yet absorbed them. I will now turn directly to the conduct literature to understand how princes like Pyrocles were meant to become mature adults, free from the stain of youthful effeminacy.

During the early modern era, an enormous quantity of conduct literature hit the presses. Though the examples I will examine were aimed at noblemen, conduct literature was a diverse project that included works for apprentices, housewives, and other groups. Alexandra Shepard has made a compelling study of the wealth of conduct literature in her book The Making of Manhood in Early Modern England, but I am interested in examining the effect of conduct literature on other forms of prose. The vast array of literature provided moral and social instruction to those of varying ranks, from advising apprentices to abstain from gambling to instructing courtiers on swordsmanship. Baldassare Castiglione's The Courtier (1528) was quickly translated into English and the book gained a reputation as required reading for an aspiring nobleman. Furthermore, the book was easily available for other writers to familiarize themselves with. ${ }^{\text {iv }}$ Sir Philip Sidney would have almost certainly been familiar with the work. Thomas Sackville's poem commending the work inserted before Thomas Hoby's own epistle to the reader is 
worth examining as it reveals the potential English consumer's approach and attitude to the work.

These royall kinges, that reare up to the skye Their pallace tops, and deck the all with gold: With rare and curious workes they feed the eye: And shew what riches here great Princes hold. A rarer worke and richer far in worth, Castilios hand presenteth here to thee. No proude, ne golden Court doth he set forth, But what in Court a Courtier ought to be.

The prince he raiseth huge and mightie walles, Castilio frames a wight of noble fame:

The king with gorgeous Tissue clads his halles, The Count with golden vertue deckes the same, Whose passing skill, lo Hobbies pen displaies

To Britaine folke, a work of worthy praise (1).

The extended metaphor here is of buildings and monuments of kings; Castiglione's book is compared to a grand palace built to show off the wealth, power, and legitimacy of a monarch. Sackville asserts that Castiglione is also performing a project of legitimacy, declaring that he demonstrates "what in Court a Courtier should be." By analyzing the necessary skills and behaviors of a perfect courtier, Castiglione legitimizes the court lifestyle and defends it against attackers who may be ready to dismiss courtiers as effeminate. "The Count" Castiglione builds in virtue, a word etymologically linked to the Latin for "man." Thus in asserting the virtue of the courtier, Castiglione is also arguing for a perfect expression of masculinity. Sackville finishes the poem by performing legitimacy himself. First, he commends Hoby's skill as a translator, ${ }^{\mathrm{vi}}$ then proceeds to assure the English public that the book is worthy and appropriate for them to read. This work by an Italian count (a country associated with effeminacy for the English, as I will argue in my analysis of Edward II) is vetted for English consumption. 
Castiglione frames his book not as a series of essays, but a series of dialogues between aristocrats in the court of Urbino. Though women are present in the discussions, the speakers are almost exclusively men. One of the speakers, the Count of Canosse, begins with an assertion of the dominance of nature in framing the perfect courtier. "Therefore it chanceth alwaies in a manner, both in armes and in all other virtuous acts, that the most famous men are Gentlemen. Because nature in every thing hath deeply sowed that privie seed, which giveth a certaine force and property of her beginning" (32). ${ }^{\text {vii }}$ The Count argues that nature is so deeply ingrained in creation that true nobility will always reveal itself. Yet in the very next paragraph, he acknowledges that nurture also plays a role in the formation of character. "And the like is in men, if they be trained up in good nurture, most commonly they resemble them from whom they come, and often times passe them, but if they have not one that can well traine them up, they grow (as it were) wilde, and never come to their ripenesse" (ibid). The tension between nature and nurture in the development of a masculine character is frequently on display in conduct literature. Elyot will focus on this tension as well. In The Courtier, nature appears to provide much of the raw material for a nobleman's character, but individuals must practice and study to perfect themselves.

One aspect of a courtier's character that he must practice is a good voice. Castiglione's Federico Fregoso asserts the importance of speaking as well as writing well.

And this doe I say, as well of writing as of speaking, wherein certain things are requisite that are not as necessarie in writing, as a good voice, not too subtill or soft, as in a woman: nor yet so boistrous and rough, as in one of the countrie, but shril, cleare, sweete, and well framed with a prompt pronunciation, and with fit maners, and gestures, which (in my minde) consist in certaine motions of all the 
bodie, not affected nor forced, but tempred with a manerly countenance and with a moving of the eyes that may give a grace and accorde with the words. (56)

This speech echoes the precepts of Roman orators Quintilian and Cicero, especially regarding proper gesture and tone of voice. Fregoso recalls the precepts of Quintilian's Institutio Oratoria. As I noted in my Introduction, Quintilian provides examples of orators whose style he disapproves of based on behavior that he terms effeminate. In Book 8, Chapter 3, when discussing how an orator might groom himself, Quintilian states, "But such ornament must, as I have already said, be bold, manly, and chaste, free from effeminate smoothness and the false hues derived from artificial dyes" (Quintilian, Institutio Oratoria web). The word effeminate does not explicitly enter in Castiglione's discussion, but its shadow is present in the warning that a courtier's voice must not be womanly, and his gestures must not be affected. The use of the word "shrill" is interesting here; in Middle English it could mean clear or bright, but by the 1500s its meaning had changed to sharp and high-pitched ${ }^{\text {viii. }}$. Its current meaning has often led to an association with women's voices, especially when women speak angrily or passionately. Yet here shrill is used as a mark of a good masculine speaking voice, along with sweet. Castiglione takes the discussion of potential effeminacy a step further by grounding it in an awareness of rank. The courtier is told to avoid a voice like "one of the countrie." As Ian Frederick Moulton argues, “...this anxiety about effeminacy is also related to class and status. Ideal courtly masculinity is not just defined against femininity, but also against lower class, overly 'masculine' behavior” (133). In citing Fregoso's remarks on a courtier's manner of speech, Moulton asserts, "When defining proper masculine behaviour, the extremes to be avoided are femina and rustico. The courtier must find a 
via media between soft feminine delicacy and rough, animal masculinity" (ibid). The concept of a middle way seems to argue that effeminacy is to be found in the extremes, either in being too feminine or in being uncontrollably masculine, but as we will see, strict standards of behavior require men to be continually guarded against the specter of effeminacy. Moulton's argument about the two extremes for courtiers to avoid are pertinent not just for Castiglione's work, but for Sidney, in which Pyrocles disguises himself as an Amazon and Musidorus as a shepherd.

Castiglione also has much to say on the nature of love, debasement, and possible effeminacy. Moulton quotes an episode from The Courtier in which a wealthy woman ignores a poor beggar and the different male characters offer their interpretations of her actions. After synthesizing the salient points, Moulton concludes, "Fifth: for a man, love involves debasement. Because of his love for the lady, an aristocrat sees himself as analogous to a naked beggar. The other gentlemen do not question or contest this analogy, though they draw different conclusions from it" (120). The theme of love involving debasement for men will be constant through this study. The principle that men are harmed by love occurs very early in Arcadia as Pyrocles is smitten with a sudden and uncontrollable desire for Philoclea. It is this all-consuming brand of love that affects Edward II and Mark Antony, as well as the various lovers in the Shakespearean comedies. As Moulton notes, the idea is so ingrained that the gentlemen in Castiglione do not question it. There is, however, a further element of debasement; men are put into a feminized position by virtue of being a courtier. "A perfect courtier is not simply a perfect warrior. He is in some ways a perfect servant. He is, in some ways, feminine. Learning to be a perfect courtier involves self-abasement as well as self-fulfillment. In 
fact, it defines fulfillment in terms of abasement. As such, it is not so different from being in love" (Moulton 130). The self-abasement inherent in being a courtier lies in subjugating oneself to another's wishes; specifically a more powerful man. In doing so, a male courtier takes on a position that women are forced to inhabit. In this sense the male courtier is effeminized, but his effeminization is viewed as natural and not in the least problematic.

Gerry Milligan offers a very nuanced reading of the politics of effeminacy in Castiglione's work. Milligan attempts to contextualize the language used in Castiglione's text: 'Language that indicates effeminacy such as 'effeminar' or 'feminile' does appear in the Cortegiano but is often left out of discussions of the 'effeminate courtier. When critics do claim that the courtier is effeminate, it is at times motivated by an ahistorical interpretation" (346). Milligan's attention to the Italian terms aids the reader in understanding the origins of the text, and his wariness to describe the courtiers as effeminate based on standards of dress is well founded. Like Milligan, I aim to interrogate the behavior that the characters themselves describe as effeminate and seek out the standards for appropriate masculine behavior.

Milligan discusses an episode in The Courtier that illuminates issues of the male gaze and effeminacy. The courtiers brush up against the ideals of beauty in their debates about the nature of the ideal courtiers. As they eventually allow discussions of beauty drop, Bernardo Bibbiena breaks the rules of the game to return to the topic and lament his own inadequate legs:

But as to the beauty of my person, I am rather doubtful, and especially as to these legs of mine which in truth do not seem to me as well disposed as I could wish; as to my chest and the rest, I am quite well enough satisfied. Now do determine a 
little more in detail what this beauty of body should be, so that I can extricate myself from doubt and put my mind at ease. (qtd. in Milligan 351)

Bibbiena's comments initially incite riotous laughter in his listeners, but Count Canossa uses Bibbiena's anxiety about his legs to bemoan the effeminacy of men who care too much for their appearance: "many...not only curl their hair and pluck their eyebrows, but preen themselves in all those ways that the most wanton and dissolute women in the world adopt...These, since nature did not make them women as they clearly wish to appear and be, should be...driven not only from the courts of great lords but from the society of all noble men" (ibid). Bibbiena made no mention of plucking eyebrows, or appearing womanly in any way, so how might we explain this reaction? His comments cause a deep-seated anxiety and the sudden invitation to observe his body sets the men on edge.

When Bibbiena asks that the others gaze upon his body and offer their opinions about his muscular chest and lackluster thighs, he infringes on more historic rules of masculine behavior. Most gender theory demonstrates that since Aristotle, the mind has been gendered as masculine and the body as feminine... it seems that Bernardo Bibbiena has offended not only by breaking the rhetorical rules of the courtiers' game, but by breaking a primary rule of masculinity. His remarks make explicit the otherwise tacit game of men watching men...Thus, by feminizing his own body, or worse, implicating all of the men in the specularization and consequent effeminization of the male body, Bibbiena threatens the homosocial structure of the gathering and therefore threatens the stability of the community. (Milligan 352-53)

Milligan's analysis is incredibly astute. It is not merely that certain forms of dress or behavior are effeminate, although they certainly can be viewed as such by the courtiers. The fear of effeminacy manifests in the fear of something wanting internally. Bibbiena's outburst demonstrates to the other courtiers a lack of awareness and judgment and his attempt to involve the others in the process of effeminization is dangerous to them. The idea that the most problematic effeminacy is internal is a recurring theme throughout this 
study. Edward, Richard, Antony, and Sejanus all demonstrate a similar disregard for the fundamental rules of masculine behavior that is so dangerous to Renaissance minds.

Furthermore, the effeminization inherent in gazing too much at a male body is relevant to Arcadia, as Musidorus participates in his cousin's effeminate scheme by dressing him in his Amazon attire. With an understanding of one of the primary texts of conduct literature, I will now turn to a well-known example by an English author, written specifically with the aim of educating English gentlemen.

Though Castiglione's book became one of the most well-known conduct books, English writers were formulating their own works independent of Castiglione. Sir Thomas Elyot's The Book of the Governor (1531) draws on ancient influences and is concerned with the public good in general but he is also explicit in creating an English setting. Elyot's volume might be termed a book on the care and keeping of a potential English gentleman from birth until death. One of Elyot's special concerns is the education of these young noblemen and the company they are surrounded with.

Semblable ordre will I ensue in the fourmynge the gentill wittes of noble mennes children, who, from the wombes of their mother, shal be made propise or apte to the gouernance of a publike weale...be sure of a nourise whiche shulde be of no seruile condition or vice notable. For, as some auncient writers do suppose, often times the childe soukethe the vice of his nouryse with the milke of her pappe...More ouer to the nourise shulde be appointed an other woman of approved vertue, discretion, and grauitie, who shall nat suffre, in the childes presence, to be shewed any acte or tache dishonest, or any wanton or unclene worde to be spoken...Perchance some wyll scorne me for that I am so serious...I verily do suppose that in the braynes and hertes of children... some pestiferous dewe of vice to...contein in it feruent and mortal poyson, to the utter destruction of a realme. (Elyot 28-30)

The lessons here include the following: character is formed early, almost from birth. Women are responsible for the early development of a child, and therefore can be blamed 
if anything goes wrong. Elyot argues that vice can be imbibed with breast milk as a warning to noblemen to choose nurses of good character for their children. The early emphasis on women is somewhat paradoxical; men are banned from the nursery in a child's early years, leaving the development of good character entirely to women. Yet at the usual age of seven years, a male child is removed from the nursery to be surrounded with the company of men. ${ }^{\text {ix }}$ The abrupt change in a child's role models from women to men has profound implications for the development of allegedly effeminate behavior. In addition, the development of a proper masculine character is a fragile thing in this excerpt; the slightest improper word or action can lead to disaster. Elyot even further asserts this opinion, saying that some may protest his serious attitude, but the brains and hearts of children are too malleable to permit the slightest degree of laxity. Elyot's insistence on such painstaking care raises a vital question; is the development of masculine virtues easy or difficult? If it is easy, then why such strict observance and the belief that an incorrect word from a nurse will derail a child's entire future? If the achievement of this perfect character is acknowledged to be difficult, then why do other texts treat behaving like a courtier as a simple matter of performing prescribed actions? As we will see, Sidney's princes are the recipients of conflicting advice and even offer contradictory advice to each other.

Tom MacFaul locates echoes of Elyot in Sidney, particularly in his depiction of the two princes and their friendship:

Arcadia's exquisite narrative balance relies on the presence of two friends, but the need for such narrative balance is caused by that pairing. This owes something to Elyot's tale of "Titus and Gisippus" in The Boke Named the Gouernour (1531). Titus and Gisippus's friendship is proved against love and against the harshness of the law: told that his friend loves his mistress Sophronia, Gisippus gives the woman to his friend; this is requited when Titus saves Gisippus from a false 
criminal charge. Sidney makes use of both these strands, but reworks them so there is less tension between the friends. (18)

MacFaul's observation is helpful here, as it makes clear that Elyot's text was familiar to Sidney, which clarifies the conduct advice that Musidorus gives to Pyrocles. MacFaul also sees Elyot's influence in the idea of two princes who have been brought up and educated together, to the mutual benefit of both men. ${ }^{\mathrm{x}}$ While MacFaul is primarily concerned with the classical nature of the princes' friendship, derived from Aristotle and Cicero. ${ }^{\mathrm{xi}}$ I am concerned with the nature of the advice that they give each other and the processes of effeminization and maturity that characterize their journey. By fully delving into Pyrocles' and Musidorus' initial interactions, their different characters, and what impact effeminacy has on the two princes, we are left with a more nuanced understanding of the process of manhood in Sidney's text.

\section{Arcadia and Masculine Norms}

I will engage in a reading of the first twenty pages of Sir Phillip Sidney’s Arcadia since many of the most important aspects of the work for the purposes of this study are introduced early: a male character's cross-dressing, the intensity of emotion in young men, and the perceived dangers of love. Pyrocles and Musidorus are explicitly stated to be quite young, only seventeen and eighteen respectively. Though Musidorus is only slightly older than his cousin, he takes on the role of an older brother or mentor to Pyrocles. The younger cousin is the first to fall in love. "Now...it was Pyrocles' either evil or good fortune walking with his host in a fair gallery newly made by an excellent artificer, which contained the duke and duchess with their younger daughter Philoclea...It is called love. Yet did not the poor youth at first know his disease" (Sidney 10-11). 
Sidney has Pyrocles fall in love through an artificial image and before long Musidorus is ready to comment on his cousin's changes in mood. "And even so do I give you leave, sweet Pyrocles, ever to defend solitariness...But I think you will make me see that the vigour of your wit can show itself in any subject; or else you feed your solitariness with the conceits of the poets...especially when they put words in the mouth of one of these fantastical mind-infected people that children and musicians call lovers" (15-16). Musidorus makes the immediate leap from solitary mood to poetry and from poetry to love. His instant scoffing about mind-infected lovers foreshadows his own descent into love.

Pyrocles reveals his cross-dressing plan to his utterly astonished cousin. "I am resolved, because all direct ways are barred me of opening my suit to the duke, to take upon me the estate of an Amazon lady going about the world to practice feats of chivalry and to seek myself a worthy husband. I have already provided all furniture necessary for it; and my face, you see, will not easily discover me" (16). In this speech, Pyrocles obliquely hints at the feminine nature of his own beauty. The more obvious meaning is that Pyrocles is not yet old enough to have a beard, and so his face will serve as appropriately nonmasculine. However, the moment serves to plant the image of Pyrocles with a feminine face in the mind of the reader. This image is confirmed when Pyrocles assumes the Cleophila disguise, and when the two princes appear in their own guises at the trial. Pyrocles' choice to present himself as an Amazon seems made to excuse his height and physical fitness; it should be noted however that this is a male fantasy version of an Amazon as seeking a worthy husband was not usually a priority for an Amazon woman. Yet Pyrocles mentions the idea of seeking a husband directly, ${ }^{\text {xi }}$ perhaps because 
his understanding is that seeking a husband is common to all women; therefore, if he

wishes to pose as a woman, he should be prepared to engage in husband-hunting.

Musidorus' reaction to his cousin's ludicrous plan and sudden intense love is

drawn from the moralizing advice of conduct books and is worth quoting at length.

And is it possible that this is Pyrocles, the only young prince in the world, formed by nature and framed by education to the true exercise of virtue? Or is it, indeed, some Amazon Cleophila that hath counterfeited the face of my friend in this sort to vex me...Remember (for I know you know it) that, if we will be men, the reasonable part of our soul is to have absolute commandment, against which if any sensual weakness arise, we are to yield our sound forces to the overthrowing of so unnatural a rebellion; wherein, how can we want courage, since we are to deal against so weak an adversary that in itself is nothing but weakness? Nay, we are to resolve that if reason direct it, we must do it; and if we must do it, we will do it; for to say I cannot is childish and I will not womanish. And see how extremely every way you endanger your mind; for to take this woman's habit, without you frame your behavior accordingly, is wholly vain...you must resolve, if you will play your part to any purpose, whatsoever peevish imperfections are in that sex, to soften your heart to receive them-the very first down step to all wickedness...Y Yet thus much of [love's] worthy effects in yourself is to be seen: that it utterly subverts the course of nature in making reason give place to sense and man to woman. For indeed, the true love hath that excellent nature in it, that it doth transform the very essence of the lover into the thing loved, uniting and as it were, incorporating it with a secret and inward working. And herein do these kinds of love imitate the excellent; for, as the love of heaven makes one heavenly, the love of virtue, virtuous, so doth the love of the world make one become worldly. And this effeminate love of a woman doth so womanize a man that, if you yield to it, it will not only make you a famous Amazon, but a launder, an distaff-spinner, or whatsoever other vile occupation their idle heads can imagine and their weak hands perform. (17-19)

Musidorus' rant against the effeminizing nature of love is an excellent grounding point

for the themes of this study. He begins by lamenting the sad state a young man of

Pyrocles' birth and education has found himself in, drawing on the concerns of Elyot. His young cousin has clearly been given the careful treatment that Elyot cautions is necessary for an infant nobleman, but something has gone wrong. Musidorus wonders if the switch from Pyrocles to Cleophila has already been made, reinforcing the image of Pyrocles as 
feminine. Musidorus deals in stark moralist terms about what it means to be a man; in this section of the speech men should be in complete commandment of their minds and bodies, and if any weakness appears on the horizon it should be struck down with prompt action. In this moment, Musidorus suggests that attaining perfect manhood is a simple matter of willpower, and if one cannot perform it is merely a childish tantrum or feminine sulking. This "deal with any weak spot immediately" attitude occurs regularly in conduct literature. Musidorus' intense dislike for the cross-dressing plan foreshadows the objections of anti-theatricalists such as Gosson and Prynne. Here, as in the anti-theatrical tracts, the wearing of a woman's apparel is inherently demeaning to a man and there is an underlying panic that once the exterior change into a woman has been made, the interior will also change. Musidorus also echoes the tract writers in his belief that wearing the Amazon dress will lead Pyrocles into feminine behavior and that is where the true path to wickedness lies. As Martha Craig notes: "Pyrocles's disguise as an Amazon signals to Musidorus a sex change from perfect to imperfect, a perversion that overthrows not just the princes' former allegiance to each other but Pyrocles's manhood, his mind, and his very soul" (90). Craig correctly identifies Musidorus' anxiety that his friend will be forever changed by this process. There is a suspicion of performance itself in this diatribe, since if Pyrocles is to counterfeit the role of a woman with any skill, he must become something other than his true self, and since women are automatically considered inferior to men, his self-worth will be tarnished by the process. To continue in an ethical vein, Musidorus evinces the belief that love of virtue should be enough to sustain a young man. This belief recurs in conduct texts, and Castiglione and Elyot both reference it. On the face of it, the argument appears simple and uncomplicated. If you love virtue, then all 
you must do is be virtuous. ${ }^{\text {xiii }}$ As we have seen in Castiglione, virtue is etymologically linked with masculinity, with the result that the pursuit and attainment of virtue is less a moral quest than a statement of manhood. Difficulties arise when the concept of virtue crosses swords with the tempest of adolescence, a time when effeminacy must be vigorously guarded against. Pyrocles' attachment to Philoclea is by no means uncommon or perverse, but to conduct writers such attachments (without the benefit of maturity and experience) are often slippery slopes that lead to feminizing behavior. Thus far in his moralizing, Musidorus sounds much less like a young prince and more like an elderly conduct book writer. The speech reads as though Musidorus is parroting pieces of instruction that he has been given. Clearly, Musidorus has internalized the warnings against effeminacy that he has been bombarded with and he is now prepared to give his cousin the same instruction.

Towards the end of the speech, Musidorus shifts from the cross-dressing plan to the problematic nature of love itself. His worries will inform the thoughts and actions of many characters throughout this study. In this segment, we have a clear indicator of the belief that love of a woman effeminizes a man. Musidorus' citation of the distaff-spinner is an allusion to the myth of Hercules and Omphale, which will recur in Antony and Cleopatra. Intense attachments, as we will see in the examples of Edward II and Richard II, often do more harm than good. Furthermore, complex and courtly pursuit of a woman can serve to make a man look foolish, as evinced by the comedies As You Like It and Love's Labor's Lost. The problem of love and whether the process of love and courtship makes a man effeminate is one that the aristocratic male characters in this study will grapple with, with limited success. Musidorus' speech provides the reader with a clear 
understanding of one of the biggest obstacles for noblemen in the early modern period; what to do with ungovernable emotions. These intense emotions will only increase as the narrative progresses.

Pyrocles takes his cousin's moralizing and dismissal of his plan in stride until Musidorus threatens to leave so that he does not have to witness Pyrocles' disgrace. Pyrocles is shaken by "this last farewell of him he loved as his own life" (22) and promptly dissolves into tears and recriminations. "'Prince Musidorus, how cruelly you deal with me! If you seek the victory, take it; and if you list, triumph... Now if you list, leave him that loves you in the highest degree; but remember ever to carry this with you: that you abandon your friend in his greatest need"' (ibid). After laying guilt on Musidorus, Pryocles utterly collapses in a display of grief and tears.

...he was unable to bear it any longer; but, gushing out abundance of tears and crossing his arms over his woeful heart, he sank down to the ground. Which sudden trance went so to the heart of Musidorus that, falling down by him, and kissing the weeping eyes of his friend, he besought him not to make account of his speech, which, if it had been over vehement, yet was it to be borne withal, because it came out of a love much more vehement...But even this kindness made Pyrocles the more melt in the former unkindness, which his manlike tears well showed...And this struck Musidorus's mind and senses so dumb, too, that for grief not being able to say anything, they rested with their eyes placed one upon another. (22-23)

This is the first instance we have in the text of a weeping male character, and the image will recur throughout. Pyrocles is not merely shedding tears; he is enacting a pageant of sadness. It is not a few tears, but an abundance of tears; his arms fly over his chest (as glossed by Katherine Duncan-Jones ${ }^{\text {xiv }}$, a standard position of melancholy often seen in paintings) and he falls to the ground. The spectacle can be read in several ways. Is this intensity of feeling correlated to the intensity of Pyrocles' love? It seems likely that Sidney would encourage this reading. However, given Pyrocles' earlier statement, the 
exchange reads as manipulative. Pyrocles desperately wants his friend and cousin to remain by his side, so he exercises the power of tears knowing that it will work. It could be tempting to read this moment as effeminate since this behavior is often linked with women. However, I argue that Pyrocles fits into a nongendered category here; that of a youth. He is so young that his face and body may still signify woman to some readers. Sidney makes this point by continual references to Pyrocles' beautiful appearance, even when he is not in the Cleophila disguise. Wearing the Amazon attire will not effeminize Pyrocles but rather accentuate the feminine features of a more androgynous youth. However, as Musidorus has warned, because Pyrocles is so young and beautiful, the disguise may transform those elements of him into something more feminine, and therefore debasing.

Pyrocles' performance works on Musidorus, who immediately rushes to bestow comfort on his cousin. Here, as in his long speech, Musidorus is taking advantage of his role as the elder cousin to serve as a protector. In his reassurances to his cousin, Musidorus urges Pyrocles not to be hurt by his speech, because if his words were too vehement, they came from a love much more vehement. In one sense, this reads as a very familial statement, as a parent might scold a child engaged in doing something dangerous. Again, taken with Pyrocles' earlier words of love in the highest degree, the moment also reads as intensely homoerotic, perhaps with a bit of jealousy mixed in. The reader is invited to question whether Musidorus' lengthy speech denouncing his cousin for falling in love masks a more passionate attachment. The protective and erotic blend echoes the relationship of Achilles and Patroclus. Pyrocles is so moved that his weeping continues, though Sidney is careful to note that these are "manlike" tears. It is as though 
the idea that this behavior might be perceived as effeminate has pressured the narrator into assigning a gender to tears. What is it about these tears that distinguishes them from any other tears, and especially from female tears? Since there is no discernible difference in male and female tears, the qualifier is only there to ward off accusations of effeminacy. By the standards of the conduct books, Pyrocles is displaying effeminacy in not properly controlling his emotions. The erotic moment continues as the two young princes kneel on the ground with their eyes fixed on one another.

The spell is broken when, despite Musidorus' intense suspicion of the plan, he assists Pyrocles in the transformation into Cleophila. This segment continues the erotic undercurrent in the relationship of the two princes. While the text is ostensibly about heterosexual attachments and the problems that arise through obsessive love, same sex desire is always present. Basilius, in love with the disguised Cleophila, desires a male subject. Philoclea worries that her attachment to Cleophila is an unnatural sin. While Gynecia is also in love with Cleophila, she is the only character in the text who can correctly interpret that the disguise hides a male body. As Musidorus helps Pyrocles get dressed, Sidney offers a lengthy description of the Amazon lady's beauty and the exact nature of her attire.

And to begin with his head, thus was he dressed: his hair (which the young men of Greece ware very long, accounting them most beautiful that had that in fairest quantity) lay upon the upper part of his forehead in locks, some curled and some, as it were, forgotten, with such a careless care, and with an art so hiding art...The rest whereof was drawn into a coronet of gold, richly set with pearls...And such [sky color satin] was the nether part of his garment; but that made so full of stuff, and cut after such a fashion that, though the length fell under his ankles, yet in his going one might well perceive the small of the leg which, with the foot, was covered with a little short pair of crimson velvet buskin, in some places open (as the ancient manner was) to show the fairness of the skin... upon his thigh he ware a sword...Such was this Amazon's attire: and thus did Pyrocles become Cleophila. (24-25) 
Pyrocles' long hair is excused from a possible suspicion of effeminacy by the explanation that men in ancient Greece always wore their hair long, and in fact the men with the longest hair were considered the most beautiful. The styling of the hair is linked to Castiglione's central concept of sprezzatura, a kind of careless elegance that was requisite for both men and women. Linked to this concept is the idea that when artifice is required, as in a careful and deliberate hairstyling, it should appear as natural as possible. In his Amazon dress, Pyrocles is careful to preserve his rank as his gold coronet inlaid with pearls demonstrates. Pyrocles' dress and accessories are overtly feminine. Apart from the sword and the traditional buskins, there is little about this costume that reads as "Amazon." Much like the idea of being an Amazon looking for a rich husband, this costume is a male fantasy of an Amazon. This is confirmed by the detail that his dress is carefully cut to reveal his leg. In addition, the "little" short buskins suggest that Pyrocles has small feet; these items of clothing are also cut to reveal the skin, though this is also excused with a parenthetical explaining the ancient custom. In discussing the Amazon's dress at length, Sidney both accentuates how feminine Pyrocles has become and explains away the details that suggest that Pyrocles has always had feminine features. Though Pyrocles himself knows that his features are more feminine and appears unbothered by it (in fact he lists it as a primary reason for his choice of disguise), the narratorial voice is obliged to assert his relative masculinity by the standards of the age. As a reader may be getting close to imagining that Pyrocles is effeminate, the narrator interrupts this train of thought. Sidney ends the description by stating "thus Pyrocles became Cleophila." While the disguise is meant to be temporary, the verb suggests a more permanent transition 
from one state into another, as a boy becomes a man. In this case, a boy becomes an Amazon, cementing the anxiety that the wearing of women's clothes will precipitate a permanent change of sex.

After he has finished dressing Pyrocles, Musidorus is so struck with his cousin's beauty that he begins to engage in flirtatious banter.

But Musidorus, that had helped to dress his friend, could not satisfy himself with looking upon him, so did he find his excellent beauty set out with this new change, like a diamond set in a more advantageous sort. Insomuch that he could not choose, but smiling said unto him:

'Well,' said he, 'sweet cousin, since you are framed of such a loving mettle, I pray you, take heed of looking yourself in a glass lest Narcissus's fortune fall upon you. For my part, I promise you, if I were not fully resolved never to submit my heart to these fancies, I were like enough while I dressed you to become a young Pygmalion.'

'Alas,' answered Cleophila, 'if my beauty be anything, then will it help me to some part of my desires; otherwise I am no more to set by it than the orator by his eloquence that pleases nobody.'

'She is a very invincible creature, then,' said he, 'for I doubt me much, under your patience, whether my mistress, your mistress, have a greater portion of beauty.' ... In such friendly speeches they returned again to the desert of the two lodges, where Cleophila desired Musidorus he would hide himself in a little grove where he might see how she could play her part. (25)

First, Musidorus "could not satisfy himself" with simply looking at the disguised Pyrocles and silently admiring his beauty. The impulse to speak and flirt with Pyrocles demonstrates the same lack of self-control that he berated Pyrocles for earlier. In a surprising turn of events, Musidorus finds the newly minted Cleophila's beauty so overwhelming that he must speak. The image of the diamond is fascinating; it suggests that Pyrocles' natural beauty is more advantageously displayed in feminine attire. What might this suggestion mean in the context of the conduct books? Musidorus' overwhelming need to admire Pyrocles as soon as he is in the Amazon attire foreshadows the objections of the anti-theatricalists. Pyrocles remains the same youth he was before, 
but the addition of the feminine dress is so enticing to Musidorus that he comes close to falling in love on the spot. There is an erotic danger inherent in this scene. Pyrocles' impulse to take on an effeminate role nearly results in him being the object of his cousin's lust. The erotic danger caused by the disguised Pyrocles will become a major thread of the later plot as multiple characters obsess over Cleophila. In his flirtation, Musidorus displays his learning by using two mythological examples, Narcissus and Pygmalion. The Narcissus example operates on two layers. First, it is ostensibly used to warn Pyrocles of the danger of vanity. Since Pyrocles is already in the grasp of love, he may take it a step further and fall in love with his own image. This also reinforces the idea that Pyrocles has not fallen in love with Philoclea in a substantial way, but only through her painting. Therefore, Musidorus teases his younger cousin about his tendency to prize image over substance by suggesting that he could fall in love with his own reflection. However, while the figure of Narcissus has come to stand for self-absorption and vanity, his extraordinary beauty hints at Musidorus' feelings. This hint is confirmed immediately after as Musidorus uses the figure of Pygmalion. As the sculptor Pygmalion famously fell in love with his creation, Musidorus has nearly fallen in love with Cleophila, whom he has helped to create. The Pygmalion myth also features a man falling in love with an insubstantial figure. In recalling Pygmalion, Musidorus realizes that his feelings for Cleophila may be intense, but they are also insubstantial since Cleophila is only a disguise. Cleophila does not respond to the flirtation, but Musidorus continues, doubting that Philoclea can possibly be more beautiful than Cleophila. His cousin dismisses this as blasphemy but uses a light tone. Sidney describes these speeches as friendly, but they appear slightly beyond friendship, especially on Musidorus' part. 
Throughout this exchange, Sidney refers to Cleophila only by name, but after the cousins finish their speeches, Sidney switches to female pronouns for Cleophila. There is no indication to the reader for some time after that Cleophila is anything other than a woman.

\section{Conclusion}

Sidney's Arcadia expands on and complicates the definitions of effeminate behavior set forth in the conduct books. A reading of the first twenty pages of the text illuminates the struggles of the young princes to follow the prescriptions of virtuous behavior. In his characterization of Pyrocles, Sidney gives the reader a young man of strong character who nonetheless struggles against the standards of proper masculinity and with the depth of his emotions. Musidorus has internalized the advice from authority figures and conduct literature. Sidney demonstrates what the pursuit of mature masculinity can look like in a youth who is still in the grip of adolescent desire. Though Musidorus eagerly parrots the sententious words he has been fed, he is no more immune to love than his young cousin. Though overall Sidney's text has elements of a romantic

comedy, there are dramatic elements. At the climax of the novel, both princes stand accused of serious sexual misconduct and Gynecia is accused of murdering her husband, Basilius. The duke's sudden awakening shifts the action back to comedy and the two princes are freed and allowed to marry their chosen partners. This sudden happy ending asks the reader to consider how seriously youthful readers are meant to take conduct literature and the proscriptions against effeminacy. The princes' disregard of the codes of conduct nearly leads to their death but their sudden reprieve suggests that perhaps the 
danger was not as drastic as it could have been. Arcadia's treatment of effeminate behavior lies midway between the humorous humiliation that leads to a mature masculinity in the comedies and the disastrous excesses that lead to destruction in the Roman tragedies and English history plays. By studying the conduct literature and Arcadia together, a picture of the treatment of effeminacy in early modern drama becomes clear and this picture informs the discussion of dramatic literature in this study. 


\section{Chapter 2: Classical Precedents: Roman Gender and Sexuality in Sejanus His Fall and Antony and Cleopatra}

How is effeminacy staged in dramatic representations of the classical period? This chapter begins my discussion of historical drama as a site for representing effeminacy. I will survey two Roman tragedies of the early Jacobean era, William Shakespeare's Antony and Cleopatra, and Ben Jonson's Sejanus His Fall, to interrogate how the standards of behavior for nobleman discussed in Chapter One play out in representation of ancient masculinity. Roman masculinity, like Renaissance masculinity, had a deeply entrenched code of values. When early modern playwrights turned to the classical world to navigate masculinity and effeminacy, the results were mixed for their audiences. William Shakespeare's Antony and Cleopatra, written between 1606 and 1608, was enormously successful. Ben Jonson's 1603 tragedy, Sejanus His Fall, by contrast, had an almost unanimously negative reception. Both these plays mobilize classical sources to discuss effeminacy, and how tragedy results from a failure to conform to codes of Roman masculinity. Jonson's Sejanus is an unpleasant, manipulative court favorite who uses his sexuality to rise above his station and chooses inappropriate erotic targets. Meanwhile, the cruel emperor Tiberius has completely abandoned the responsibilities of state to wallow in lust with adolescent victims. Shakespeare's Mark Antony, well known for his obsession with Cleopatra, matches the definition of effeminacy as he loses his military prowess and subsumes himself to the Egyptian queen's desires. I argue that both Jonson and Shakespeare utilize their classical sources to aid in a portrayal of effeminacy that resonates with an early modern audience; therefore I will examine Tacitus and Plutarch in detail to locate the genesis of these Renaissance Romans, Sejanus and Antony. 
Jonson researched Sejanus extensively and he was proud of his work. In the printed edition of Sejanus, Jonson presents a careful note to the readers outlining his project and making excuses for departures from the classical tragic form. "First, if it be objected that what I publish is no true poem in the strict laws of time, I confess it; as also in the want of a proper chorus...in truth of argument, dignity of persons, gravity and height of elocution, fulness and frequency of sentence, I have discharged the other offices of a tragic writer" (50). Anne Barton comments on Jonson's pride in his erudition: "Truth of argument, in the sense of historical accuracy, is validated on the whole by the host of references to Tacitus, Suetonius, Juvenal, Dio Cassius, Pliny and Seneca which Jonson proudly supplied- although he seems to have felt free to make certain adjustments" (95).

Shakespeare also borrowed from classical sources for Antony and Cleopatra, though his sources do not form such a lengthy list. He drew primarily from Plutarch's "Life of Marcus Antonius." Jonson observed the differences between himself and Shakespeare and "Jonson's most common criticism was that Shakespeare took tragic rules too lightly" (Brzozowska 196). Whatever Jonson believed about Shakespeare's abilities; the other playwright enjoyed far greater success with Roman tragedy. Natalia Brzozowska contends that Jonson's failures resulted from a pedantic and poorly understood application of the rules of tragedy.

An effective tragedy must elicit particular emotions through the depth of suitably constructed characters, the moral dilemma (conflict) and the final catharsis. Jonson failed in areas regarding the use of the ancient tragic model; what is more, his well-known devotion to historical detail resulted in a heavy-handed style and laboured character creation. (191-192)

Jonson rested on the knowledge that his speeches were drawn almost verbatim from sources such as Tacitus and he prided himself on accurate translation. What Jonson failed 
to realize was that the emotional plane of his tragedy was sorely lacking. All these technical faults originate from one cause; Jonson's inability to calibrate his play for his audience. Jonson envisioned that his play would be a popular success ${ }^{\mathrm{xv}}$ but ignored the fact that most London playgoers were not as interested in the minutiae of Tacitus as he was. Nevertheless, Jonson's careful attention to his source material creates a reliable portrait of the state of affairs, especially masculinity and gender roles in Tiberian Rome.

Both Shakespeare and Jonson make good use of their historical sources and create revealing discussions about Roman masculinity. Historically accurate depictions of masculinity are not always the goal. Philip Goldfarb attributes this to Jonson's inability or unwillingness to separate Roman characters from the Jacobean political atmosphere. "Jonson recontextualizes the plot of Sejanus so that the historically accurate events that occur are understood within an anachronistic political world more recognizable to Renaissance Englishmen than Tiberian Romans. This in turn encourages topical interpretation of the action" (55). Paradoxically, Jonson's play was understood to be a commentary on Jacobean politics even though Jonson's depiction of the state of Rome is far more nuanced than Shakespeare's. Jonson and Shakespeare create male characters who traverse the wide road of ambition and sexuality, with tragic results. Antony's ambition slackens in age and he prefers to spend his time with his Egyptian lover, putting him in the category of effeminacy, defined as being controlled by a woman. Sejanus sublimates all his other desires, especially lust, to his craving for power. Livia is just a steppingstone to the ultimate prize; control over Rome. Furthermore, Sejanus fails to exercise prudence, which was deemed a masculine trait in the Jacobean era ${ }^{\mathrm{xvi}}$. He incorrectly assumes that his management of the emperor's affairs have made him so 
crucial that he can demand Livia's hand. Tiberius, meanwhile, has given up everything but darkly hedonistic pleasures, to the point where Arruntius enumerates the emperor's perversions before describing him as a "stale catamite" (4.404). Jonson and Shakespeare mobilize their classical sources to create Romans who occasionally have Renaissance ideas of masculinity, and in whom the impetus for honor and glory is tempered with inappropriate erotic targets. I will now move on to literary analysis of both plays before a discussion of how the plays operate in performance. I argue that despite Jonson's more thorough research, he and Shakespeare embark on the same project of making effeminacy central to the dramatization of Roman history.

\section{Sejanus, Lust and Power}

Relentless jockeying for political power is on display in the first scene of Sejanus. Republican-minded Silius dismisses Sejanus' clients Secundus and Natta with a stream of bitter invective.

...These can lie,

Flatter, and swear, forswear, deprave, inform,

Smile, and betray...

Laugh when their patron laughs; sweat when he sweats;

Be hot and cold with him; change every mood...

Look well or ill with him-ready to praise his

His lordship if he spit, or but piss fair.

Have an indifferent stool, or break wind well. (1.1.27-40)

The cavalier references to bodily functions mark the speech as particularly Jonsonian.

Silius' speech is ostensibly directed at Sejanus' followers, but every line can also

correspond to how Sejanus behaves with his corrupt master Tiberius, establishing a clear picture of the political hierarchy in Rome for the audience. Tiberius has a follower to applaud if he pisses fair, and that same follower has a string of others to do the same for 
him in that hope that he will curry favors for them with the emperor. The bitterness in this speech is primarily directed at the two men, but Silius also indirectly laments the servile nature of the state of Rome itself. Speeches such as this one bear out Brzozowska's claim that "the state of Rome receives more attention in rhetoric and descriptions than any character" (198). Sabinus echoes his friend's assertion with "Alas! These things / Deserve no note, conferred with other vile / And filthier flatteries, that corrupt the times" (41-43). The times themselves are corrupt and corroding the state. For Brzozowska, Jonson's continued emphasis on the state is a failing. "If the state is the focal point of a play, it may be hard to evoke fear and pity, since one cannot easily identify with the entrapment of a 'state"' (198). According to Aristotle's classical model, a tragedian needs to evoke pity and fear for a tragedy to be successful. ${ }^{\text {xvii }}$ However, I contend that Jonson's intervention is in applying classical rules to the depiction of a state in decay. He attempts to evoke pity and fear through representations of masculinity in this corrupted state, which resonate for both Jacobean and modern audiences.

Silius and Sabinus obliquely criticize the manhood of the servile flatterers. The recently deceased Germanicus is presented as a model for proper Roman masculinity and his widow Agrippina remains the gatekeeper for traditional Roman values. Arruntius, another Roman with Republican sentiments, comments on the lack of the old virtue after Germanicus' death: "His name was, while he lived, above all envy; / And, being dead, without it. O, that man! / If there were seeds of the old virtue left, / They lived in him" (1.1.117-120). Silius goes even further in his praise of the dead hero: "He had the fruits, Arruntius, / More than the seeds...He was a man most like to virtue; in all, / And every action, nearer to the gods, / Than men" (120-126). Jonson constructs pity through his 
description of a virtuous military hero who has died mysteriously. "I am sure / He was too great for us, and that they knew / Who did remove him hence" (156-158). Sabinus whispers that Germanicus was likely poisoned. "When men grow fast / Honoured, and loved, there is a trick in state / (Which jealous princes never fail to use) /...All which snares / When his wise cares prevented, a fine poison / Was thought on" (159-174). In this exchange, Jonson cites Tacitus, Annals, II.lxix, ${ }^{\text {xviii }}$ which details Germanicus' suspicions of Gnaeus Piso, as well as Piso's trial for the murder of Germanicus. The section is one of the longest and most detailed in Tacitus, relying on lengthy court documents. Considering Jonson's direct translations for other speeches, it is remarkable that he gives this episode a mere aside. The brevity works to his advantage, however, as the reader is left with an uneasy sense of foreboding that will increase as the tragedy builds to its climax. This scene also works to convince the viewer that proper Roman masculinity is dead, and that there may be foul play involved. To paraphrase Hamlet, there is something rotten in the state of Rome, and it is the failing of masculine virtue.

Jonson spends a large amount of the first scene constructing the current problems with masculinity in Rome and creating a link to past glories through the praise of Germanicus. After the three Senators whisper about the murder plot, Sejanus enters, followed closely by his hangers on. Silius and Arruntius are disgusted. "Now observe the stops, / The bendings, and the falls...Most creeping base!" (1.175-177) Jonson introduces the character of Sejanus through a discussion with Eudemus, a physician. Sejanus wants a favor from Eudemus and attempts to win him over through humor, specifically by describing women's bodily functions.

...Faith, which of these

Is the most pleasant lady, in her physic? 
Come, you are modest now...

Why sir, I do not ask you of their urines,

Whose smell's most violet? Or whose siege is best?

Or who makes hardest faces on her stool?

Which lady sleeps with her own face a-nights?

Which puts her teeth off, with her clothes, in court?

Or which her hair? Which her complexion?

And, in which box she puts it? These were questions

That might, perhaps, have put your gravity

To some defence of blush. (1.301-312)

Ironically, Sejanus shares the same ease in discussing bodily functions as his detractor Silius. However, while Silius snidely brings these functions up as an indicator of how far Roman masculinity has fallen, Sejanus shows an improper amount of interest in what occurs in the bathrooms of wealthy Roman ladies. Despite Sejanus' protest that he is not asking Eudemus about any of these things, the simple mention of them gives readers the image of noble ladies, one of whom is the widow of the great emperor Augustus, on the toilet. The speech reads like one of Jonson's satirical poems. However, Sejanus' speech does have the effect of defining the character and his basic personality. He can be crude if he sees a need, nothing is sacred to him, and he is prepared to do or say anything to achieve his goals. In this speech, Sejanus reads as neither a good Roman nor a good Jacobean.

Jonson continues the action in a slightly satirical vein in Act 2. The audience is introduced to the character of Livia, but unfortunately this is her only appearance. She asserts herself as an active member in the plot to poison her husband, Drusus, an incident described by Tacitus in IV.iii of the Annals. ${ }^{x i x}$ She schemes with Sejanus and Eudemus to find the perfect person to give Drusus the poison.

Eudemus: I say Lygdus.

Sejanus: Lygdus? What's he?

Livia: An eunuch Drusus loves. 
Eudemus: Ay, and his cup-bearer.

Sejanus: Name not a second.

If Drusus love him, and he have that place,

We cannot think a fitter...

Livia: But he must be wrought

To th'undertaking with some laboured art...

Sejanus: What is he then?

Livia: Faith, only wanton, light.

Sejanus: How! Is he young? And fair?

Livia: A delicate youth.

Sejanus: Send him to me, I'll work him. (2.13-24)

This discussion of Drusus and Lygdus speaks eloquently about Roman sexuality.

Jonson's use of Lygdus as Drusus' eunuch and cupbearer undermines the rehabilitation of Roman masculinity that the play is attempting to locate in Drusus. He is initially positioned as something of a successor to Germanicus though Silius, Arruntius, and Sabinus have differing opinions of him. Arruntius gives him the description reminiscent of Prince Hal. “A riotous youth, / There’s little hope of him” (1.106). Sabinus offers a milder opinion. "That fault his age / Will, as it grows, correct. Methinks he bears / Himself, each day, more nobly than other; / And wins no less on men's affections / Than doth his father lose. Believe me I love him" (107-111). Drusus, then, is depicted as young and immature but coming into proper Roman manhood. His relationship with the light and wanton eunuch Lygdus may have felt alienating to Renaissance minds. There is something of a disconnect here between Renaissance and Roman sexuality. Roman men were not always averse to relations with other males (but Lygdus, because of his status as a eunuch, would not have been awarded use of the term vir, $\operatorname{man}^{\mathrm{xx}}$ ), if they took the dominant role. Lygdus, conveniently, is a eunuch. It would have been truly unthinkable for a Roman man to put himself in the submissive position, as that was considered tantamount to a total loss of masculinity. The Romans referred to the act of a man 
submitting to anal intercourse as “muliebra pati" or "having a woman's experience. ${ }^{\text {xxi }}$ For educated Renaissance minds, the mention of Lygdus as Drusus' cupbearer would have instantly recalled the myth of Zeus and Ganymede, with its homoerotic implications.

Of special note is the beautifully ambiguous "Send him to me, I'll work him" that Sejanus utters. What does he mean when he says that he will "work" Lygdus? Does he merely mean to sweet talk him with flattery, as he does Livia, or does he have something sexual in mind? Jonson had carefully read Tacitus, so he would have been aware of a passage in Book Four, Chapter 10. "After seducing Livilla into crime, Sejanus, it is alleged, also secured the eunuch Lygdus' allegiance by means of a sexual liaison, Lygdus being dear to his master, because of his age and good looks, and one of his foremost servants. Then, when the place and time for the poisoning had been agreed upon...Sejanus...changed the scenario." (141) Tacitus refers to this entire situation as a rumor but he does not dismiss the possibility that Sejanus enticed Lygdus to the poisoning through sex. Jonson's reading of the scenario is just ambiguous enough to leave room for doubt.

\section{Male Bonds and Sejanus}

Jonson's text occupies a peculiar place in the depiction of male bonds. Some of the invective directed at Sejanus and his string of followers seems to be in part an indictment of the client system. While Jonson and Shakespeare would have been familiar with the system of artistic patronage, the Roman empire depended on the relationship of wealthy aristocrats and their clients. The hierarchical system that Silius and Sabinus observe would not have been out of place in Tiberian Rome but the system was not 
immune to critiques of the power dynamics and the exchanges of favors it produced.

Noblemen were visited by their clients daily. The client system represented exchanges of favors, whether legitimate or otherwise. Sejanus functions as a glorified version of a client to Tiberius. He performs various tasks for the emperor in return for patronage and prestige. Brandon Christopher examines their relationship through a model that was more familiar to Jacobeans: master and secretary ${ }^{x x i i}$. Sejanus is a particularly exalted secretary. The play opens with the news of Sejanus' statue being erected in Pompey's theater and Tiberius shows respect for Sejanus' intellect. "Dearest head, / To thy most fortunate design I yield it" (3.502-3). However, the distinction of rank remains abundantly clear and it is here that Sejanus begins to make the serious mistake of overstepping boundaries. Tiberius' tone rapidly shifts as Sejanus grows bolder.

Sejanus: Sir, I have been so long trained up in grace... Nor have I ever, yet, been covetous Of overbright and dazzling honours

Tiberius: Tis confessed.

Sejanus: The only gain, and which I count most fair Of all my fortunes, is that mighty Caesar Had thought me worthy his alliance. Hence Begin my hopes.

Tiberius: H'mh? (3.504-14)

When he begins to suspect that Sejanus might be about to ask for a large favor, Tiberius craftily pretends to be barely paying attention, but Sejanus is not dissuaded from his aim and immediately asks for Livia's hand. Tiberius covers his displeasure well, offering rational explanations for why he should refuse; Livia, having been accustomed to luxury, will not be happy with a private citizen, and the Senate and the nobles will not accept such favoritism. Though Sejanus pretends to humbly acquiesce, "I am restored, and to my sense again, / Which I had lost in this so blinding suit. / Caesar hath taught me better to 
refuse / Than I knew how to ask" (3.577-80), he complains bitterly when Tiberius exits and begins to fully execute his plan to remove Tiberius from the management of the empire.

...Well, read my charms, And may they that lay hold upon thy senses As thou hadst snuffed up hemlock, or ta'en down The juice of poppy and of mandrakes. Sleep, Voluptuous Caesar, and security Seize on thy stupid powers, and leave them dead To public cares, awake but to thy lustsThe strength of which makes thy libidinous soul Itch to leave Rome...

By this I shall remove him both from thought And knowledge of his own dear affairs... And these that hate me now, wanting access To him, will make their envy none, or less. For when they see me arbiter of all, They must observe-, or else, with Caesar, fall. (3.595-622)

Sejanus mobilizes Tiberius' lustful character to obtain power for himself. Here, as in Sejanus' seductions of Livia and Lygdus, power is the ultimate desire for Sejanus. There is a sinister yet beautiful intimacy as Sejanus describes the dreamlike fog of lust that will surround Tiberius, lending to a possible interpretation of an erotic bond between the two men. However, Tiberius is not so easily led as Sejanus has supposed. His imprudent demand for Livia's hand has aroused Tiberius' suspicions and the emperor engages Macro as a counter spy. He is particularly dismayed by what he perceives as Sejanus' unchecked ambition. ${ }^{\text {xxii }}$ Brandon Christopher argues that though the master-secretary relationship opened avenues of intimacy between men of different ranks, there were limits to how far that intimacy could extend. The relationship between Sejanus and Tiberius is a cogent example of Christopher's model. Sejanus exercises an unprecedented amount of control over Tiberius; he controls who Tiberius sees, what he reads, and what 
he hears. It is this new power that leads him to expect a grander prize, as he views Livia, as a reward for his faithful service. To Tiberius, Livia's rank remains an insuperable barrier and an inappropriate object of desire for a man that he still views as a servant. This clash over rank and what kinds of service constitutes a servant sets the wheel in motion for Sejanus' eventual downfall as Tiberius is finally moved to get rid of Sejanus because he has failed to perform the role of a proper Roman man. His lack of awareness of barriers of rank and appropriate erotic targets makes him as dangerous as his murderous schemes.

\section{The Effeminate General}

The word effeminate is not likely to enter the mind of a modern audience member who is asked to describe the character of Mark Antony. He is a passionate man and an astute general, but these qualities are subjugated to his obsession with Cleopatra. Shakespeare's main source for Antony and Cleopatra, Plutarch's "Life of Antony," carefully enumerates how Antony's extravagant personality complemented the Egyptian queen's. Plutarch, who lived more than seventy years after Antony's death, is less interested in a precise historical timeline than he is in painting a portrait of a great man. Plutarch has some bias against Antony, but he freely admits Antony’s virtues. On Antony's appearance, he writes that "His beard was well grown, his forehead broad, his nose aquiline, and these features combined to give him a certain bold and masculine look, which is found in the statues and portraits of Hercules. In fact, there was an ancient tradition that the blood of the Heracleidae ran in Antony's family" (276). The comparison to Hercules is instructive and essential to the construction of Antony's character. Comparisons to the Greek hero are frequent both in the historical record and in 
Shakespeare. One facet of the Hercules myth, his encounter with Omphale, underlines a critical moment in Antony and Cleopatra, as I will discuss. Plutarch reveals that Antony drew on the tradition that his family was descended from Hercules to construct his own identity, both in appearance and in behavior.

Antony liked to believe that his own physique lent force to the legend. He also deliberately cultivated it in his choice of dress...And indeed it was these same 'Herculean' qualities that the fastidious found so offensive- his swaggering air, his ribald talk, his fondness for carousing in public, sitting down by his men as they ate, or taking his food standing at the common mess-table-which made his own troops delight in his company and almost worship him. His weakness for the opposite sex also showed an attractive side of his character, and even won him the sympathy of many people, for he often helped others in their love affairs, and always accepted with good humour the jokes they made about his own. Besides this, his open-handed nature and generosity with which he showered rewards upon his friends and soldiers alike laid a splendid foundation when he first set out upon the road to power, and when he had established himself, these qualities raised his authority to still greater heights, even after he had begun to undermine it by innumerable acts of folly. (274-275)

In this description, Mark Antony represents a very different kind of Roman masculinity from Plutarch's portrait of Brutus, or the Shakespearean version of Brutus. In many ways, he is like his mentor Julius Caesar, especially in his familiarity with his troops. The hero worship from the troops that Plutarch mentions helps the reader understand how Antony inspired such devotion in characters like Enobarbus and Eros. Even as Antony's soldiers begin to see the façade crumbling and his mistakes appear in sharper focus, they still feel immense love for their general. Plutarch's description of Antony reveals a man who is inherently likeable and charismatic, though his extravagant generosity may lead readers to conclude that Antony could also be easily led by another forceful personality. What Antony is not in this description is a loser, as he has sometimes been portrayed in criticism. Lisa S. Starks also takes exception to this argument, claiming that "Certainly, he does not meet the qualifications of a Classical hero, but he is, nevertheless, an 
exemplary hero, or rather an exemplary 'antihero'...This role is, by its very definition, a rejection of Classical heroism and an acceptance of an alternative masculine identity" (244). For Starks, Antony represents a blending of medieval and renaissance traditions of love, with Cleopatra cast in the role of the dominant lady whom men are eager to submit to. Starks makes a compelling argument, but she does not take the second half of the play entirely into account.

When it comes to the figure of Cleopatra, the historical record gives her as grand a persona as Shakespeare's tragedy. Though Plutarch is careful to inform the reader that Cleopatra was not renowned for physical beauty, he accepts that her larger than life personality was immensely attractive to a man like Antony. "Such being Antony's nature, the love for Cleopatra which now entered his life came as the final and crowning mischief which could befall him. It excited to the point of madness many passions which had hitherto lain concealed, or at least dormant, and it stifled or corrupted all those redeeming qualities in him" (292). Plutarch grants Antony's obsession with Cleopatra a life force of its own. "But now the fatal influence, that is his passion for Cleopatra, which for a long while had lain dormant in his heart, and which appeared to have been charmed away by wiser counsels, suddenly gained strength and blazed into his life" (303). Finally, he brings up the trope of enchantment, which Shakespeare's Antony mentions toward the end of the play. "Such was his passion to spend the winter with her that he took the field too early and conducted the whole campaign in a disorderly fashion. It was as if he were no longer master of his own judgment, but rather under the influence of some drug or magic spell” (305). 
Shakespeare follows Plutarch's lead in marking Antony following Cleopatra from the sea battle as a turning point in his ability to reason. "And it was now that Antony revealed to all the world that he was no longer guided by the motives of a commander nor of a brave man or indeed by his own judgment... he allowed himself to be dragged along after the woman, as if he had become part of her flesh and must go wherever she led him" (332). In this quotation, the word effeminacy is not mentioned but its meaning is implicit. Both Roman readers and Renaissance audiences would read this moment similarly. Antony's masculine quality of judgment has been entirely subsumed to one woman's will. He is, whether through drugs, enchantment, or simply his own passion, under Cleopatra's control. It is the significance of this moment that Starks misses, for though traditions of courtly love do sometimes have men submitting to women, Cleopatra is no medieval courtly lady but the ruler of a Roman province. Shakespeare's depictions of his main characters tallies with the historical record. A closer look at key passages in the play will illuminate how Shakespeare utilizes the discussion of effeminacy which he gleaned from his source.

\section{Antony and Cleopatra: "This Dotage of Our General's."}

Antony and Cleopatra begins not with a battle or a chorus speech, but with a speech from an extremely minor character. Philo's function in the play is to introduce the audience to Antony's obsession with Cleopatra and how the common soldiers feel about their general's love affair. Philo's discomfort with Cleopatra's race provides evidence that, like Sejanus, Antony's choice of erotic target is inappropriate, which is a sign of effeminacy. Philo enters in conversation with Demetrius, another soldier, evidently enraged by the behavior that he has seen Antony and the queen engaging in. 
Nay, but this dotage of our General's O'erflows the measure. Those his goodly eyes, That o'er the files and musters of the war Have glowed like plated Mars, now bend, now turn The office and devotion of their view Upon a tawny front. His captain's heart, Which in the scuffles of great fights hath burst The buckles on his breast, reneges all temper, And is become the bellows and the fan To cool a gypsy's lust.

Flourish. Enter ANTONY, CLEOPATRA, her ladies, the train, with eunuchs fanning her.

Look where they come:

Take but good note, and you shall see in him

The triple pillar of the world transformed

Into a strumpet's fool. Behold and see. (1.1.1-13)

The speech effectively captures the audience's attention and prepares them for Antony and Cleopatra's entrance. Many critics have seized on the "tawny front" moment to discuss Shakespeare's mobilization of race in this tragedy. Kim F. Hall notes that "Cleopatra's darkness makes her the embodiment of an absolute correspondence between fears of racial and gender difference and the threat they pose to imperialism...[Philo's] language, typical of orientalist discourse, makes it clear that Shakespeare is at pains to have us see a black Cleopatra" (219-20). Ania Loomba, however, argues that despite Philo's description and others in the play, it can be difficult for readers to visualize Cleopatra physically. ${ }^{\text {xxiv }}$ Philo indisputably means "tawny" as a put-down and it echoes other mentions of Cleopatra's race later in the play. While Sejanus is punished for choosing an erotic target who is inappropriate in terms of rank, Antony's lover is positioned as racially inappropriate. Beyond matters of race, however, the depth of Philo's rage is reserved for how Antony's behavior and his character have changed because of his affair. Through a series of contrasting images, Philo juxtaposes the aweinspiring general with the effeminate lover. The word "dotage" is an especially effective 
choice, because while it can mean "foolish affection," the Oxford English Dictionary lists its primary definition as "The state of one who dotes or has the intellect impaired, now esp. through old age; feebleness or incapacity of mind or understanding; infatuation, folly; second childhood; senility." ${ }^{\text {’xv }}$ The two meanings coexisted in Jacobean England and Philo combines the images of a foolish lover with a foolish old man to subtly inform the audience that Antony is now a middle-aged man. Finally, the choice to give this speech to such a minor character rather than a supporting figure like Enobarbus reflects the fact that Antony's behavior has been noticed by his entire army, not only the soldiers he is closest to. As a result, his decisions will have wide-reaching effects leading to the tragic climax in Act Five.

Cleopatra is clearly Antony's partner in the excesses which have so angered his army and she will have an equal role in the events which lead to their deaths. In her earliest appearances in the play, we have the impression of a fiercely sensual and powerful woman who flouts the societal conventions expected of her sex. Cleopatra, however, has no interest in submission, as a brief exchange with her attendant Charmian demonstrates. The queen orders her servant Alexas to find Antony and inform him of his mistress' mood.

Cleopatra:

...If you find him sad,

Say I am dancing; if in mirth, report

That I am sudden sick. Quick, and return. [Exit Alexas]

Charmian:

Madam, methinks, if you did love him dearly, You do not hold the method to enforce

The like from him.

Cleopatra:

What should I do I do not?

Charmian:

In each thing give him way; cross him in nothing. 
Cleopatra:

Thou teachest like a fool: the way to lose him.

Charmian:

Tempt him not so far. Iwis, forbear.

In time we hate that which we often fear. (1.3.3-12)

Charmian offers the conventional advice for wives: give your husband his way in every matter. Cleopatra is not only uninterested in such advice; she proclaims it foolish and that it will make her lose Antony. Behind these two opposing arguments lurk salient points. Charmian fears that Antony will eventually grow tired of Cleopatra's contrarian ways, while Cleopatra believes that if Antony wanted the kind of relationship that Charmian describes, he would be back in Rome with his wife, Fulvia. It is instructive that this conversation occurs just before Antony tells Cleopatra that Fulvia has died. Her spirit haunts this conversation as Cleopatra revokes both traditional gender roles and Roman femininity, as represented by Fulvia.

As she rejects the Roman way of performing femininity for herself, another crucial passage illustrates Antony's abandonment of the brand of Roman masculinity he has spent decades attaining. Lonely while Antony is away, Cleopatra regales her servants with tales of their past exploits.

Charmian:

...'Twas merry when

You wagered on your angling, when your diver

Did hang a salt fish on his hook, which he

With fervency drew up.

Cleopatra:

That time?-O times!-

I laughed him out of patience; and that night

I laughed him into patience; and the next morn, Ere the ninth hour, I drunk him to his bed, Then put my tires and mantles on him, whilst I wore his sword Philippan. (2.5.15-22) 
Plutarch mentions the anecdote with the salt fish as illustrative of Antony's childish amusements $^{\mathrm{xxvi}}$ but while he does note that Antony and Cleopatra enjoyed disguising themselves, he does not describe Antony wearing her clothing. This moment seems to be Shakespeare's invention. Stephen Orgel notes that this moment echoes the legend of Hercules and Queen Omphale. “Omphale set him to doing women's household work; in some versions of the story this was intended simply as a humiliation but in others it was a device to keep him by her side...Ancient representations of the couple show Hercules in Omphale's garments and holding her distaff, while she wears his lion skin and bears his club" (Impersonations 78). It should be noted that Antony does not fully participate in the cross-dressing, as he is seemingly lying drunk in bed. Cleopatra takes it upon herself to put her "tires and mantles" on him, another indication of his disregard for conventional gender roles. The moment is recalled and reversed when Cleopatra helps Antony arm himself for battle and puts the sword on him. What is perhaps most startling about this cross-dressing moment that sets it apart from similar moments in Renaissance drama is that we do not know how Antony reacted. Orgel comments that "It is, after all, Omphale who dresses Hercules in her garments, Cleopatra who puts Antony into her tires and mantles. These are represented not as male stratagems, but as transformations that give women power and pleasure" (82). That this action gave Cleopatra pleasure is unmistakable from her speech; it is presented as a moment of levity that she continues to enjoy in memory and a treasured moment in their relationship. It is Antony's pleasure, or lack thereof, that is missing from these accounts. Was he angry when he awoke dressed as the Queen of Egypt? Did he laugh? Was it a moment of pleasure for him that he otherwise would not have had access to? Cleopatra keeps that part of the memory private. 
What we can know is that to both Roman and Renaissance minds, the moment is an effeminizing one. It contributes to some of the negativity that continues to dog critical perceptions of Cleopatra and may also be partly responsible for the strain of criticism that brands Antony a "loser" that Starks identified. As critics like Orgel and Laura Levine note, this moment also feeds into Renaissance anti-theatrical fears about cross-dressing: "Male spectators, it is argued, will be seduced by the impersonation, and losing their reason will become effeminate, which in this case means not only that they will lust after the woman in the drama, which is bad enough, but also after the youth beneath the woman's costume, thereby playing the woman's role themselves" (Impersonations 27). Elizabethan fears about gender and lust lend an ostensibly heterosexual moment a homoerotic angle. The male spectator will feel lust not only for the figure of Cleopatra wearing a sword, but also for the youth wearing her tires and mantles, a figure that Cleopatra herself references at the end of the play. ${ }^{\text {xxvii }}$ For the Renaissance audience, this short speech not only raises gender fears but establishes an effeminizing moment for Antony so that the turning point of the sea battle will not come as a surprise.

The image of Antony abandoning the sea battle to follow Cleopatra and her defecting navy held a great resonance for Plutarch, as I have argued, and it also marks a turning point in Shakespeare's drama. The shift begins in 3.7, when Antony, partly at Cleopatra's urging, is determined to fight with Octavius Caesar by sea. Enobarbus offers cogent counter arguments and even an unnamed soldier attempts to convince him, but Antony will not be swayed. The soldier comments "By Hercules, I think I am i'th' right" and Camidius responds "Soldier, thou art; but his whole action grows / Not in the power on't. So our leader's led, / And we are women's men" (3.7.66-69). The soldier's 
invocation of Hercules reminds the audience of Antony's ancestry while Camidius' remark leaves little doubt about how Antony's army interprets their general's deference to Cleopatra. After Cleopatra's flight, Scarus reports the outcome: "She once being loosed, / The noble ruin of her magic, Antony, / Claps on his sea-wing, and (like a doting mallard), / Leaving the fight in height, flies after her. / I never saw an action of such shame. / Experience, manhood, honour, ne'er before / Did violate so itself' (3.10.17-22). The image of Antony as a lovesick duck may read as amusing to a modern audience but to the initial Jacobean audience, the image reveals how far Antony has fallen in his obsession for Cleopatra. This moment is a major factor in Enobarbus' decision to switch sides, though his loyalty to Antony remains so steadfast that he dies of a broken heart before even reaching Caesar's camp. In the aftermath of the aborted sea battle, a major change occurs in Antony and Cleopatra's relationship as well. Antony is disgusted and ashamed of himself and fiercely angry at Cleopatra, while she begs his forgiveness.

Antony:

O, whither hast thou led me, Egypt? See How I convey my shame out of thine eyes

By looking back what I have left behind 'Stroyed in dishonour.

Cleopatra:

O my lord, my lord, Forgive my fearful sails! I little thought

You would have followed.

Antony:

Egypt, thou knew'st too well

My heart was to thy rudder tied by th' strings, And thou shouldst tow me after. O'er my spirit

Thy full supremacy thou knew'st, and that

Thy beck might from the bidding of the gods

Command me.

Cleopatra:

O, my pardon!

Antony:

Now I must 
To the young man send humble treaties, dodge

And palter in the shifts of lowness, who

With half the bulk o'th' world played as I pleased,

Making and marring fortunes. You did know

How much you were my conqueror, and that

My sword, made weak by my affection, would

Obey it on all cause. (3.11.50-67)

Though Antony asks Cleopatra for a kiss and forgives her, even pleading with her not to shed a tear, the close intimacy between them does not recur until Antony's death scene, and later, Cleopatra's. This exchange is immensely powerful. Contrary to her earlier appearances, Cleopatra has little to say in this moment while Antony holds forth on her power over him. In this exchange, Antony is aware of just how much in Cleopatra's thrall he has been, remarking that she could have stopped him from doing the will of the gods and calling her "my conqueror." Furthermore, Romans were by Antony’s day known throughout the Western world as conquerors, but here the roles are observed. Antony is both a man and a member of a conquering nation, but Cleopatra strips these identities from him. His speeches will build up to the moment when he calls her "thou spell" in 4.14 ${ }^{\mathrm{xxviii}}$ and his reference to his affection weakening his sword foreshadows him bellowing "O, thy vile lady! / She has robbed me of my sword" (4.14.22-23) at Mardian. Shakespeare creates an arc in which Cleopatra describes herself literally taking Antony's sword and Antony insisting that she has robbed him of it and his manhood with it. Throughout the exchange in 3.11, he refers to her as "Egypt," and while he has done so before and will again, his usage deliberately references her status as a ruler. Egypt has conquered Rome, personified by Cleopatra and Antony themselves. Antony, despite Enobarbus' later assertion that he is not in control of himself, is aware of how much he has subjugated his identity to Cleopatra's. In his speeches, Antony begins to believe the 
view that he has been enchanted, expressed by Plutarch and several characters in Shakespeare's text. In this scene, Antony recognizes what his Jacobean audiences would have defined as an effeminizing pattern in his relationship with Cleopatra and he attempts to change it. He is ultimately unsuccessful since Cleopatra even controls his death.

Antony attempts suicide in 4.14 believing that Cleopatra has taken her own life. Though he is fatally wounded, he lives long enough to be reunited with Cleopatra. In Antony's attempted suicide, the passion that he attempts to stifle as he realizes that Cleopatra has affected his masculinity returns. While Antony's suicide lacks the gravitas that Shakespeare affords Brutus in his earlier Roman tragedy, Shakespeare's project for Antony is different. The protagonists' deaths are in the mode of Romeo and Juliet and they express an eroticism in death that Starks cogently identifies: "Antony courageously gives himself over to the shattering effects of masochism, exposing his vulnerability. Antony's wounded penetrated body draws its erotic charge from medieval to early modern representations of the hero-martyr" (253). It is no coincidence that Antony's servant, whom he orders to kill him, is named Eros. Just as the force of eros has been the cause of great passion and destruction in his life, Antony desires to meet his death by Eros' hand. However, Eros is unable to obey his master and stabs himself instead, acting as the final catalyst for Antony's botched suicide. Starks notes that Antony is more frequently an object of desire than Cleopatra in the play; in his dying scene he retains that role.

\section{Sejanus in Performance}


From its disastrous beginnings in 1603, the production history for Sejanus is fraught. The play has been performed so seldom that in 2005 Royal Shakespeare Company director Gregory Doran claimed that his was the first modern production of Sejanus. ${ }^{\text {xix }}$ For centuries, Jonson's tragedy was dismissed as too scholarly for popular performance; in Doran's hands, it is a tense and politically relevant tale of corruption. The star of the production is undoubtedly William Houston's Sejanus. Houston plays Sejanus very much in the vein of Jonson's comic over-reachers identified by Anne Barton but he also displays vulnerability and raw despair as his fall occurs. He throws himself into the seduction scene with Livia, apparently having sex with her against a pillar as the physician Eudemus plays lookout. Doran also includes what happens when Sejanus "works on" the eunuch Lygdus. Houston engages in male-male intercourse as the top with Peter Bramhill's Lygdus, climaxing on the lines "Tell proud Jove / Between his power, and thine, there is no odds. / 'Twas only fear first in the world made gods" (2.161163). As in Jonson's text, Tiberius enters saying "Is yet Sejanus come?" immediately after those lines. The fact that the line suddenly became a sexual joke went down poorly with several critics.

The image of Sejanus seducing Lygdus was a powerful and radical depiction of male-male intimacy and an indication of the character's utter willingness to exchange sex for power. Critical treatment of this moment relied on implicit homophobia. Benedict Nightingale writes for the Times, "You also feel that the dramatist takes a certain relish in Sejanus's own jubilant excesses, which here include surreptitious buggery that hastily ends when the emperor enters" (28 ${ }^{\text {th }}$ July 2005). In the Stratford Herald, Preston Witts notes that "William Houston as Sejanus...gives the character every ounce of moral 
turpitude at an actor's disposal. This is a man headed for a very big fall; a man whose lust for power and sexual gluttony (there's a buggery scene that does not shock in its context here) make him deserving of a very nasty end" ( $28^{\text {th }}$ July 2005$)$. Finally, in the Independent, Paul Taylor claims that "Power for [Sejanus] is a coldly erotic turn-on. 'Twas only fear first in the world made gods,' he declares in a scene where Doran has him working up to this rhetorical climax in an act of clandestine, dominant buggery" $\left(29^{\text {th }}\right.$ July 2005). Though other critics mention Sejanus' sexuality, the use of the word buggery in these three reviews is a disquieting, othering experience, perhaps pointing to a pervasive fear of homosexual intentions. While Sejanus undoubtedly uses his sexuality to obtain political power, the critics make his encounter with a male person a sign of his degradation. Doran shows Sejanus engaging in the same behavior with Livia, and intimacy with men is not automatically more obscene than intimacy with women or evidence of moral turpitude. Furthermore, this choice is warranted not only by Jonson's text, but by Tacitus, Jonson's source for this episode.

While this discomfort over the male intimacy is disappointing, Doran's production won high marks with critics for its political relevance. Sejanus has always been politically current, so much so that Jonson was called before the Privy Council to answer treason charges. The depiction of an emperor known for sexual behavior with men (he is described as a stale catamite in Act Four ${ }^{\mathrm{xxx}}$ ) and his cunning favorite was understood to be a commentary on Jacobean politics. Brandon Christopher argues that some audience members would have taken Tiberius for King James. ${ }^{\text {xxi }}$ It is true that Sejanus predates the rise of powerful men in James' court, particularly George Villiers, the Duke of Buckingham, however, James' relationships with men during his years as the 
King of Scotland were topics of gossip as he ascended the English throne in $1603 .{ }^{\text {xxii }}$ While King James was a relevant political analog for Jacobean audiences, modern audiences saw George Bush and Donald Rumsfeld in Jonson’s Romans. ${ }^{\text {xxxiii }}$

Besides its strong topical content, Doran's production succeeds in its tense pacing thanks to judicious cuts to the text. Doran does succeed in elevating the play beyond stale classical speeches. "Doran is unafraid to bolster the play with the kind of florid detail post-I, Claudius audiences expect from their Roman capers” (Victoria Segal, Sunday Times, $31^{\text {st }}$ July 2005). Drusus' death by poisoning occurs onstage and he coughs and seizes dramatically. Silius commits suicide on stage, leaving a blood trail that Tiberius steps around in a beautiful moment of hypocritical squeamishness. The success of the production owes much to these kinds of details, borrowed from Robert Graves' 1934 novel I, Claudius and the 1976 BBC television production. Perhaps Sejanus needs a work like Graves' novel to popularize Roman history for a contemporary audience. Far from being a dull, plodding affair, the recording of Sejanus brought moments of metatheatrical joy, bridging the Renaissance and the modern era. The performance represented the summit of Roman popular culture and deftly tackled Jonson's discussions of Roman masculinity.

Despite the success of Doran's production, however, Sejanus His Fall remains a seldom produced Renaissance play. Twelve years later, the play has yet to achieve the critical revival that such a fascinating production might have inspired. It is at this point that the play's faults come into sharper focus. Contrasted with Antony and Cleopatra, mounting a production of Sejanus requires far more groundwork, not to mention an extremely adept director. Antony and Cleopatra remains more familiar ground for a 
director and an audience. I will now discuss how Shakespeare utilizes his source, as well as character creation and rhetoric, to analyze the problem of Roman masculinity on the verge of collapse.

\section{Antony and Cleopatra in Performance}

While the production history for Antony and Cleopatra is much longer and more varied than the production history of Sejanus, the popularity of the play has fluctuated over the centuries. Sara Munson Deats enumerates some of the challenges that the play poses:

Total disregard of the unities of time and place; forty-two scenes ranging the entire known world; a cast of thirty-four main characters...these are a few of the challenges that confront any director of Antony and Cleopatra. A performance history of the play thus becomes a narrative of attempts to surmount these formidable obstacles. These monumental problems may be one reason that the play, alone among Shakespeare's great tragedies, was not staged for over 150 years after its presumed premiere in 1607. (34-35)

The play's length and enormous cast of characters represent two of the same difficulties that performances of Sejanus must overcome. Antony and Cleopatra also has another problem that Jonson's tragedy does not face; its title characters. While they no doubt represent the highlight of the play for an audience, they represent an immense challenge for any actors attempting to portray them. The role of Cleopatra, with her mercurial nature, is difficult for any actor, while the role of Antony brings its own challenges. Any actor playing Antony “must capture both the titan's greatness and the lover's vulnerability; he must join in Cleopatra's sportive seduction, indulge in debilitating sexual infatuation, explode into jealous rages, and survive his botched suicide and hoisting onto Cleopatra's monument, all without diminishing his heroic stature" (Deats 
35). Such a role is perhaps impossibly demanding for any actor. Perhaps not coincidentally, of the performances I studied for this chapter, even when Antony and Cleopatra were played by actors of equal talent and renown, critics found fault much more often with Antony. This suggests that when actors do successfully convey effeminacy, critics may still respond with disgust even though an actor's choices may be validated by the text.

Actors playing Cleopatra, however, frequently have sexist biases to contend with. One of the most successful $20^{\text {th }}$-century productions was Glen Byam Shaw's 1953 production starring Peggy Ashcroft and Michael Redgrave. Both lead actors were praised by critics, but Kenneth Tynan had a different take. "There is only one role in Antony and Cleopatra...which English actresses are naturally equipped to play. This is Octavia, Caesar's docile sister...the great sluts of world drama, from Clytemnestra to Anna Christie, have always puzzled our girls; and an English Cleopatra is a contradiction in terms" (qtd. in Deats 50). Richard Findlater agreed, proclaiming that "no English player, it seems, can act Cleopatra, and no actress of any other nation can speak it" (qtd. in Deats 51). While it is unsurprising that critics of the 1950s would reduce a character like Cleopatra to a "slut," it reveals a sexist attitude surrounding the character's sexuality that an actor must break though. This brand of critical patriarchal thought extended further into the $20^{\text {th }}$ century. In 1998, Helen Mirren and Alan Rickman took on the legendary roles. Paul Taylor comments on the nature of the rumors surrounding Mirren's casting. "Would Helen Mirren do a total strip for Cleopatra's death scene, or would she create the sensation of the decade by managing, for once, to keep her kit on?" (Independent $22^{\text {nd }}$ October 1998) Before Helen Mirren even stepped onstage, she had to deal with a gauntlet 
of tabloids who were more concerned with her body than her talent for reciting blank verse.

This production of Antony and Cleopatra was the subject of more critical ire than any other I studied. Both Mirren and Rickman's performances were criticized, especially Rickman’s Antony. Benedict Nightingale commented that “Alan Rickman’s rumpled, woebegone Antony sometimes left me feeling that Eeyore had been miscast as Tigger. Rickman has gravity and a glum charisma-but where is the recklessness, the warmth, the emotional munificence, the hedonism?” (The Times of London $21^{\text {st }}$ October 1998). Paul Taylor felt that Rickman, "communicates here all the galvanizing charisma of a deceased halibut. How could such a lackluster figure have inspired intense love and loyalty in his troops?" (Independent $22^{\text {nd }}$ October 1998). These critical statements reflect the obsession with masculinity inherent in the text; just as Antony is condemned by the Romans for effeminacy, Rickman's performance as Antony drew harsh remarks about his masculine vitality. Many critics indicted the actors for a lack of sensuality, as Kenneth Tynan felt in his review of the 1953 production. "Helen Mirren and Alan Rickman may be regarded as the acme of middle-aged sexiness on screen. But as Antony and Cleopatra, whose epic passion for each other proves the death of them, they rose to erotic ardour last night with little more enthusiasm than a pair of glumly non-mating pandas at the London Zoo" (Nicholas de Jongh, Evening Standard $21^{\text {st }}$ October 1998). The crux of the matter here seems to be that critics expected the sensuality to outweigh the Shakespeare. Rickman ${ }^{\mathrm{xx} x i v}$ gives the impression of an Antony who had grown weary of the world of ambition, and while critics may have missed the rash impulsiveness they expect from Antony, Rickman 
provided an aging soldier who no longer needed or wanted to conform to the Roman view of masculinity.

The American Shakespeare Center took a different approach for their production of Antony and Cleopatra in fall 2015. Their lead characters took the stage in spectacularly sensual fashion. Cleopatra (Sarah Fallon) rode Antony (James Keegan) onto the stage like a horse, rapping his shoulders with a riding crop. The initial image was sadomasochistic. Not only did this image immediately invoke the idea of Antony as under Cleopatra's sexual control, it also reproduces the frontispiece of the anonymous 1561 work, The Deceyte of Women. Anthony Fletcher discusses this image, in which a woman rides and beats a man crawling on the ground, as indicative of the gender fears of the period. ${ }^{\mathrm{xxx}}$ Though this is a modern production, its choices interpret the gender concerns of the period when the play was first written and performed. The sensuality of the piece continued, as Cleopatra insinuated the idea of sexual play, rather than billiards, with her attendants. This choice gave a sly reinterpretation to Charmian's "My arm is sore" (2.5.4). Fallon and Keegan were both aware of the endless mood shifts their characters must go through and they performed them without ever fully losing the sympathy of the audience. The production also cleverly dealt with the problem of hoisting Antony into Cleopatra's monument. In previous productions, the American Shakespeare Center has hauled the actor onto the balcony and felt that it detracted from the play. For the 2015 production, Cleopatra and her women remained on stage while Antony was hauled through a trap door. This eliminated unintentional humor and preserved the dignity of the moment. Both actors were especially moving in their death 
scene and there was an added verisimilitude in the fact that Fallon and Keegan were close to their characters' historical ages.

The company returned to Antony and Cleopatra again in fall 2019. As with their previous production, much of the emphasis was on the sensuality. Antony and Cleopatra were pushed on stage on a mattress, invisible at first beneath silken sheets. Their moans of passion, however, were indistinguishable. This created an erotic joke much like the one in Sejanus as Philo proclaimed, "Look where they come." When the two leads emerged from the sheets, Antony's kohl eyeliner and Egyptian dress were clearly visible. Not content to allow Antony to be on top, Cleopatra climbed on top of him, solidifying Philo's fears that Antony is subservient to her lust. While Geoffrey Kent's Antony clearly preferred spending his time with Cleopatra, he proved willing to adopt Roman habits when necessary, sitting with a wide stance during negotiations with Octavius in a clear display of masculine posturing. His chameleon changes in masculine presentation depending on context were admirable and created an Antony who was obsessed with Cleopatra, but also dynamic and commanding. This was an Antony who would not be called a loser. Zoe Speas' Cleopatra matched Antony's passion and their verbal exchanges created a tempestuous but ultimately rewarding relationship. In a talkback, Kent revealed that he envisioned their characters as a mismatched high school couple that the entire school is rooting against. ${ }^{\text {xxvi }}$ His image was apt, as Antony's ill-advised obsession is on full display, but the pair's "us against the world" mentality resonated as Antony fully shed his Roman ideals of masculinity.

The production histories of Sejanus and Antony and Cleopatra reveal that while both plays have pitfalls for directors and actors alike, successful productions of both are 
possible. These plays have more in common than most critics have been willing to concede, and both can be incredibly powerful tragedies. Successful productions of both plays will illuminate the concerns of masculine behavior and effeminacy inherent in the texts and make those concerns legible to a modern audience. Though Rickman tried to portray a jaded, tired kind of Roman masculinity, his choices did not register with the critics. James Keegan's Antony resonated far more powerfully as a man who could not help his erotic obsession even as it goes against his Roman values. Geoffrey Kent's Antony relished in his Egyptian makeup and threw Roman masculinity to the winds. Finally, William Houston's Sejanus made it abundantly clear that he had reached the limits of Roman masculinity and did not care about limitations. The central male characters in Jonson and Shakespeare's Roman tragedies illustrate the boundaries of acceptable masculine behavior and warn of the consequences inherent in gender transgression. They leave us with questions: did Sejanus seduce Lygdus and enjoy it? Did Antony enjoy wearing Cleopatra's tires and mantles? The large gaps in the performance history of these plays suggests that Renaissance audiences suspected that the answer to both questions was yes.

\section{Conclusion}

Jonson and Shakespeare's Roman plays provide very different experiences upon reading them. Due to the flaws discussed by Anne Barton and others, Sejanus does not provide a very pleasurable reading experience. Though Antony and Cleopatra is extremely long, Shakespeare's language is at its best. ${ }^{\text {xxvii }}$ Both these plays shine in their depiction of Roman sexuality and standards of masculinity, and these themes are 
especially illuminated by performance. Since Sejanus is so little known, a good performance is especially vital for this piece. Through the medium of performance, Sejanus' erotic excesses and the inappropriate nature of his love object become clearer, as does Sejanus' dominance in relation to the old emperor, Tiberius. A performance can aid the audience in understanding the work through tactics such as color-coded togas for the senatorial factions. In addition, other performance choices illuminate concerns in the text. For example, by opening the play with a somber funeral ode for Germanicus, the audience will already know his name and understand his importance before Silius and Sabinus lament that Roman masculinity has died with him. Antony and Cleopatra, as several performance reviews indicate, often hinges on the chemistry between actors. Antony so transgresses the bounds of masculinity both through Cleopatra's race and her dominance over him, that only performance can help the audience truly come to grips with his transgressions. Watching Antony joyously allow Cleopatra to ride him while his eyes are covered with makeup, as his soldiers look on in disgust, creates a vibrant picture for an audience that lingers long after the play is over. 


\section{Chapter 3: Skipping Kings and Minions: Reading England's Effeminate Kings}

Christopher Marlowe's Edward II (1592) and William Shakespeare's Richard II

(1595) center on medieval kings who share a fondness for fine clothing, intimate

relationships with men and the presumption of effeminacy. Edward and Richard lived

within the same century and both suffered the fate of being deposed and promptly

murdered. Marlowe and Shakespeare's treatment of these ill-suited monarchs remains

prevalent in the British cultural imagination today. Richard II has a long and storied

performance history, beginning with the late $1590 \mathrm{~s}$. The late $20^{\text {th }}$ and $21^{\text {st }}$ centuries have

seen groundbreaking performances of Richard II, from Fiona Shaw and David Tennant's

masterful stage performances to Derek Jacobi and Ben Whishaw on television. Edward

$I I$, though performed less frequently than Shakespeare's play, remains a popular choice.

Derek Jarman's explicitly queer 1991 film established Marlowe's play as the queer early modern text. Though Edward II's performance history is not as lengthy, the character of Edward appears in startling places. The BBC sketch comedy show That Mitchell and Webb Look featured a medieval monarch going doe-eyed over a foppish musician called Lucentio and giving him every possible title. His advisor suggests that he should "remember just to have sex with him and not to give him any important jobs" (That Mitchell and Webb Look Season 3 Episode 5). The sketch combines humor with a startlingly accurate take on Edward and his favorite, Piers Gaveston.

Ultimately, where Edward and Richard coalesce is in their transgression of the norms of masculinity, particularly royal masculinity. Both plays represent their relationships with men as a major factor in their downfalls. Chapter One discussed aristocratic codes of conduct and patterns of masculinity. This chapter will focus on what 
a failure to adhere to these codes means when the individual is the monarch. James I's Basilikon Doron, written to his son and heir, Prince Henry, offers a specific and detailed guide on performing royal masculinity. My readings of Edward II and Richard II will interrogate how these texts mobilize the idea of failures of masculine behavior to critique these deposed medieval monarchs. I argue that effeminacy is represented as a signifier of political stability for both Edward and Richard. The chapter will close with analysis of important film and stage productions of both plays, concluding with a female-led Richard II created according to Renaissance rehearsal conditions at the Blackfriars Playhouse in Staunton, Virginia.

\section{Modeling Royal Masculinity}

James I's Basilikon Doron was published twice, first in 1599 and again in 1603 (Smith Homosexual Desire 14). In this work, James both asserts how he plans to govern and lays out an explicit model for his successor to follow. The work received a surge of interest in the wake of James' succession to the throne. Citizens were eager to read the work to understand what kind of king they had been dealt. Though Edward II and Richard II predate James' pamphlet, Basilikon Doron outlines the precepts of royal masculinity and the divine right of kings that interest Marlowe and Shakespeare. Appropriately, the work begins with a sonnet extolling the connection between monarchs and the divine.

GOD giues not Kings the stile of Gods in vaine, For on his Throne his Scepter doe they swey: And as their subjects ought them to obey, So Kings should feare and serue their God againe If then ye would enjoy a happie raigne, Obserue the Statutes of your heauenly King, And from his Law, make all your Lawes to spring: 
Since his Lieutenant here ye should remain, Reward the iust, be stedfast, true, and plain, Represse the proud, maintayning aye the right, Walke alwayes so, as euer in his sight, Who guardes the godly, plaguing the prophane:

And so ye shall in Princely vertues shine, Resembling right your mightie King Diuine. (Basilikon Doron Argument)

Kingship is constructed as the ultimate example of service to God. Monarchs are accountable to God alone, but they should be firm and just in their service. The laws of earth should be derived from the laws of heaven, as James will explain later in the work. By strictly following the example of Christian virtues, a king will be a mirror for God. The virtues of steadfastness, honesty, humility, and so forth, are not exclusive to men, but James assumes that his successors will be male. He addresses the work to "Henry, my dearest sonne and natural successor" ( $B D$ 3). It is natural that Henry should be James' successor because of his position as the eldest child and a male child. James demonstrates a benign fatherly affection in the preface, but his concerns lie more with making sure that Henry will be a good king. "To conclude then, I charge you, as euer yee thinks to deserue my Fatherly blessing, to follow and put in practise, as farre as lyeth in you, the precepts hereafter following... For I protest before that Great GOD, I had rather not bee a Father, and childlesse, then bee a Father of wicked children" (BD 3-4). James must be a strict father because his position requires it. His words echo the words of Shakespeare's King Henry IV as he laments that his son Prince Hal is so wayward, too much like "the skipping king" Richard. James also sets up the book as an instructor for Henry on how to behave in different circumstances since he cannot always be there for his son (4).

James is firm in his precepts on marriage. Though his own marriage was somewhat complicated, ${ }^{\mathrm{xxxviii}}$ he upholds marriage as the standard for heterosexual 
relationships. Careful to remind Henry to choose a wife of appropriate breeding and religion, he also hammers home to strict importance of marriage vows and sexual abstinence. "When yee are Maried, keepe inuiolably your promise made to God in your Mariage; which standeth all in doing of one thing, and abstayning from another: to treat her in all things as your wife, and the halfe of your selfe; and to make your body (which then is no more yours, but properly hers) common with none other" (BD 36). Given James' proclivity for creating male favorites, as discussed in Chapter 2, James' hypocrisy may also seem evident in his insistence in listing "sodomy along with witchcraft, murder, incest, poisonings, and counterfeiting of currency as 'horrible crimes that ye are bound in conscience never to forgive" (Smith Homosexual Desire 14). James' somewhat baffling attitude is the result of his position as a king. He is all too aware that marriage and succession are of ultimate importance for a monarch and that those considerations must fall before any personal feelings. James can separate the construction of his royal masculinity from his own personal identity as a man who desires other men. Both Edward and Richard have difficulties in their relationships with their queens, and Edward has considerable difficulty separating his feelings for Gaveston from his duties as a monarch.

\section{Edward II and the Limits of Same-Sex Desire}

From the opening of the play to his murder, Edward is firm in his devotion to men, especially his favorite, ${ }^{\text {xxix }}$ Piers Gaveston. The play opens with Gaveston eager to return to his beloved after the death of Edward's father. "Sweet prince, I come; these, thy amorous lines / Might have enforced me to have swum from France, / And, like Leander, gasped upon the sand, / So thou wouldst smile and take me in thy arms" (1.6-9). His 
words are framed as those of romantic love; Leander being a famous self-sacrificing

lover. But Gaveston has no intention of self-sacrifice; instead, he longs to create elaborate entertainments for the new king.

Do. These are not men for me; I must have wanton poets, pleasant wits, Musicians, that with touching of a string May draw the pliant King which way I please.

Music and poetry is his delight;

Therefore I'll have Italian masques by night, Sweet speeches, comedies, and pleasing shows;

And in the day, when he shall walk abroad, Like sylvan nymphs my pages shall be clad, My men like satyrs grazing on the lawns Shall with their goat-feet dance an antic hay; Sometime a lovely boy in Dian's shape, With hair that gilds the water as it glides, Crownets of pearls about his naked arms, And in his sportful hands an olive tree To hide those parts which men delight to see... Such these as these best please his majesty. (1.49-70)

This elaborate catalog of lascivious entertainments serves multiple purposes. It tells the audience something about Gaveston. He is immediately classified as a hedonist who offers his king wanton poetry and naked boys instead of sober and wise counsel. While his reference to the boy puts himself in a position of power, Gaveston also fits the definition of effeminacy here. He has little to no interest in affairs of state; he only cares for pleasure. Descriptions of Gaveston's clothes in later scenes will confirm the suspicions that this speech raises. The entertainments that Gaveston proposes include Italian masques and a boy attired like a classical goddess. Jonathan Goldberg finds more evidence of the seductive yet dangerous allure of cross-dressing in the boy in Dian's shape, yet Gaveston throws the allusion aside almost immediately. "Neither Gaveston nor Edward wears dresses. The familiar linking of boy and woman is disarmed, summoned 
up to be put aside again" (115). Though Sinfield dismisses Goldberg's account as too literal, it is fascinating that Gaveston obliquely references cross-dressing. Whether the boy-woman connection is made again or not, Gaveston lays the groundwork for a pattern of effeminization. These proposed entertainments are held in opposition to the English way of life, yet Gaveston is sure that his king will receive great pleasure from them. Edward himself has not even appeared onstage and already his masculinity has been called into question. Gaveston's description of the king as pliant is especially significant, demonstrating that he believes that he has a degree of control over the king. Subsequent events in the play will prove that Edward is under Gaveston's sway.

Immediately after Gaveston's speech, Edward enters and begins to quarrel with his nobles about Gaveston. The nobles are envious that a relative commoner like Gaveston should enjoy the favoritism of the king. Instead of listening to their concerns, even if he does not agree, Edward doubles down. Gaveston overhears everything and notes his hatred of the aristocracy, "That Earl of Lancaster I do abhor... That villain Mortimer, I'll be his death" (1.1.75-80). He even smirks "Well done, Ned" (97) when his king puts down the nobles. Gaveston deliberately uses a diminutive form of Edward's name, further demonstrating that he has far more power than is appropriate. After all the nobles except Kent have made their exit, Gaveston is reunited with Edward.

Edward:

I cannot brook these haughty menaces:

Am I a king and must be overruled?

Brother, display my ensigns in the field;

I'll bandy with the barons and the earls, And either die or live with Gaveston.

Gaveston:

I can no longer keep me from my lord.

Edward:

What, Gaveston! Welcome! Kiss not my hand; 
Embrace me, Gaveston, as I do thee!

Why shouldst thou kneel; knowest thou not who I am?

Thy friend, thy self, another Gaveston!

Not Hylas was more mourned of Hercules

Than thou hast been of me since thy exile.

Gaveston:

And since I went from hence, no soul in hell

Hath felt more torment than poor Gaveston. (1.1.133-146)

Edward is frustrated with his nobles and reminds Kent that he is the one in power, though Edward's displays of might are frequently unsuccessful throughout the work. The king's insistence that Gaveston not kneel would be shocking to an early modern audience given the absolute authority of a sovereign over a subject. In their first interaction, Edward is showing both his high regard and love for Gaveston and his tendency to twist their relationship into one of equals. Edward seems to be referencing the Platonic idea of the second half of the soul here, which reinforces how Edward views his relationship with his favorite. He also references Hercules and Hylas, a tragic example of homoerotic love that Mortimer Senior will return to later. Edward proclaims, "I here create thee Lord High Chamberlain, / Chief Secretary to the state and me, / Earl of Cornwall, King and Lord of Man" 1.153-155). This is an immense amount of power, and though Gaveston offers a modest objection and Kent calmly suggests that perhaps one title would be better, Edward is undeterred in his objective. James also gave his favorites political power and rewarded them with titles, but he understood that this much power in the hands of one man is not a good idea. Edward is paradoxically expressing effeminacy by not conforming to the masculine virtues of kingship. His obsessive devotion for one man is constructed as feminine. Alan Sinfield frames Edward's problem similarly. "Edward is finally effeminated (as the term was used)- not by his homosexuality... but by his excessive dependence on Gaveston... Whatever his sex/gender role in respect of his lover, 
Edward renders himself effeminate through his failure in manly competence" (110). Gaveston is not exactly the problem here, but Edward's clinging devotion is.

James encouraged his son Henry to be faithful and courteous to his queen despite his marital problems, but Edward has nothing but problems with his queen, Isabella. It is apparent from their first meeting onstage that Edward is not fond of her and dislikes being in her company. The royal couple have an heir, though from their behavior it is difficult to understand how. Isabella is understandably upset at her husband's cold treatment and rails at Gaveston. "Villain, 'tis thou that robb'st me of my lord." Gaveston throws her words back at her. "Madam, "tis you that rob me of my lord" (4.160161).While it may be tempting to sympathize with the king and his favorite, Gaveston either ignores or does not care about the duties that Edward owes to his queen. Isabella movingly speaks of her distress. "Would when I left sweet France and was embarked, / That charming Circe, walking on the waves, / Had changed my shape, or at the marriageday, / The cup of Hymen had been full of poison...For never doted Jove on Ganymede / So much as he on cursed Gaveston" (4.171-81). Through her suffering and neglect, Isabella is vulnerable to falling into adultery herself. It is no surprise when we discover her affair with Mortimer and her treason against her husband. While there is no denying the beauty of Edward and Gaveston's love, particularly as they perform the romantic gesture of exchanging miniatures upon Gaveston's banishment, the obsessive nature of that relationship proves harmful to Edward's reign. For David Stymeist, "Edward and Gaveston constitute a cultural threat because they insist that their homoeroticism not be divorced from their political and social identities" (237). This argument succinctly 
summarizes the issue of homoeroticism, but I contend that it is specifically the performance of effeminacy that unnerves the nobles surrounding Edward and Gaveston.

Though the nobles are opposed to Gaveston, there is a peculiar kind of tolerance in their framing of the relationship. Their chief concern is Gaveston's low status. The two Mortimers debate the nature of Edward and Gaveston's relationship. Mortimer Senior offers many historical precedents. "The mightiest kings have had their minions; / Great Alexander loved Hephaestion; / The conquering Hercules for Hylas wept; / And for Patroclus stern Achilles drooped. / And not kings only but the wisest men...Then let his grace...enjoy that vain light-headed Earl, / For riper years will wean him from such toys" (4.392-02). He proposes that the relationship of Edward and Gaveston is just one in a long line of such homoerotic relationships, at the same time suggesting that Edward will get over such devotions as he matures. Sinfield astutely notes that a minion is not exactly what Edward wants; his heaping of titles on Gaveston suggests that he wants an equal (109). Bruce Smith notes that though the other lords may cast Edward and Gaveston in the roles of master and minion, "For all that, the role of 'minion' does not quite fit Gaveston. Both in age and in the political power he wields, he is not a boy...And he enjoys tremendous power, politically over other men and psychologically over his supposed 'master' Edward” (Homosexual Desire 213). The speech is paradoxical in several ways. If the wisest men have loved other men, then why should Edward give Gaveston up? Furthermore, the heroic relationships Mortimer Senior mentions are all marked by death. This speech indicates that for all the beauty inherent in the relationship between a king and his favorite, it frequently ends in disaster. Mortimer Junior claims that does not care about their erotic behavior, but he is intensely jealous of Gaveston's 
newfound wealth. "Uncle, his wanton humor grieves not me, / But this I scorn, that one so basely born / Should by his sovereign's favor grow so pert, / And riot it with the treasure of the realm / While soldiers mutiny for want of pay" (4.403-07). There is a certain justice in Mortimer's remarks, but though he seems to care about the soldiers who are not being paid, his primary concern is that he feels mocked by Gaveston and his fancy Italian fashions. "He wears a short Italian cloak, / Larded with pearl; and in his Tuscan cap / A jewel of more value than the crown. / Whiles others walk below, the King and he / From out a window laugh at such as we, / And flout our train and jest at our attire. / Uncle, "tis this that makes me impatient" (4.414-20). Though Mortimer Junior expresses dismay at Gaveston's Italian fashions, his true discomfort lies in the way that Edward has legitimized his relationship with Gaveston. Stymeist argues that "If Edward had maintained his male lover solely in a sexual capacity, then the nobles could simply categorize and dismiss Gaveston as catamite, whore, or ingle (male prostitute); what menaces them is Edward's demand that Gaveston be politically recognized and given official status as a royal consort" (238). Stymeist's point underscores the presumption of effeminacy inherent throughout the text; by his obsessive devotion to Gaveston, and his refusal to keep their relationship in the easily labelled paradigm of king and catamite, Edward enacts a process of effeminization that leads to extreme political instability. Just as Achilles wept for Patroclus, Edward is soon forced to weep for Gaveston. One of the Spencers berates the king for weakness as he waits for news of Gaveston. "My lord, pardon my speech. / Did you retain your father's magnanimity, / Did you regard the honor of your name, / You would not suffer thus your majesty / Be counterbuffed of your nobility. / Strike off their heads, and let them preach on poles" (11.15-20). For Spencer, 
Edward's distaste for violence and his inclination to forgive is an insurmountable weakness, and yet another indication of the king's presumed effeminacy. He protests that Edward his allowing his barons to control him, which a strong king would not suffer. Edward agrees with Spencer's assessment that he has been too mild, but it is ultimately too late to save Gaveston or the tatters of his reign. Gaveston is slain offstage and Isabella conspires with Mortimer to oust her husband and put her son on the throne.

Edward's speech giving up his crown is touching, and Shakespeare's Richard II owes much to it. "Here, take my crown- the life of Edward too. / Two kings in England cannot reign at once. / But stay awhile, let me be King till night, / That I may gaze upon this glittering crown; / So shall my eyes receive their last content" (20.57-61). He also expresses love and admiration for his son, echoing King James' hopes for his son's glorious reign. "Commend me to my son, and bid him rule / Better than I. Yet how have I transgressed, / Unless it be with too much clemency...the next news that they bring / Will be my death, and welcome it shall be; / To wretched men death is felicity" (20.121-127). Edward cannot understand that his transgression lies in falling short of the required constructs of masculinity. He allowed his personal feelings for another man to take over everything else and turned his queen against him. As a result, he has been usurped by his own son and all he can is await his fate. Joel Altman understands this speech as Marlowe's attempt to justify Edward as a victim. "Paradoxically, the more he expresses his blindness the more sympathetic this child king appears, which suggests that Marlowe understood his problem and forgave it. That he could make us sympathize as well...is the achievement of a most intricate dramaturgy" (367). Since Marlowe allegedly claimed that "all they that love not tobacco and boys were fools" (qtd. in Bray 20) his project of 
sympathizing with the maligned king is understandable. Altman makes an important point here. Aside from not being an effective king, Edward also fails as a human being in several instances, particularly in his harshness to Isabella. For his executioners, however, his effeminacy and his transgressions against masculine norms are the true crimes that cannot be overlooked.

The death scene of Edward II is notorious, yet there is considerable confusion on how it should be staged. Christopher Shirley succinctly notes both the scene's notoriety and its vagueness: "We all know what happens at the end of Edward II. Or at least we think we do" (279). Lightborne, the king's murderer, requests a red-hot spit, a table, and a featherbed. The famous chronicler Holinshed described the murder in gruesome detail. "they kept him down and withal put into his fundament an horn, and through the same they thrust up into his body an hot spit...the which passing up into his entrails, and being rolled to and fro, burnt the same, but so as no appearance of any wound or hurt outwardly might be once perceived" (qtd. in Wiggins and Lindsey xxxi). Holinshed explains that this creatively cruel assassination was meant to leave no marks on the king's body. Naturally, the act of thrusting the spit into the king's body takes on the echoes of the acts of sodomy that Edward is said to have committed and echoes the presumption that for a powerful man that act constituted effeminacy. In Marlowe's play, the stage directions are unspecific on how the murder should be staged; the featherbed seems not to be used and Lightborne only asks for the table to be placed on Edward's body. Martin Wiggins and Robert Lindsey, in their edition of the play, add a stage direction calling for the table to press on Edward while Lightborne murders him with the spit. Christopher Shirley argues that the absent stage directions call for a reader or an audience member to fill in the gaps: 
"The particulars of Edward's death, in other words, promote a judgment of his life; the more gruesome those particulars are, the more Edward seems a victim of political machinations and unspeakable cruelty" (280). For Shirley, the violence that a reader imagines or an audience views being inflicted on Edward's body is a marker of sympathy. I argue that the more specific the violence, the stronger the indictment of effeminacy. This notorious murder represents a final act of effeminization. From the ancient Greeks to the early moderns, participating in male-male intercourse in the receiving role was tantamount to a complete loss of masculinity. Young boys or slaves might fill this role, but it was unthinkable that one adult male should submit to another in this fashion. As discussed in Chapter Two, the Romans emphasized this point so strongly that the act of a man submitting to anal intercourse was referred to as muliebra pati or “having a woman's experience" (Walters 31). Edward's murder is notorious for the presumption that a king allowed himself to be the bottom in the relationship. Whether Edward was a submissive partner in anal sex or not, his treatment of Gaveston as an equal and his obsessive deference to Gaveston's wishes marks him as a bottom. In his death, Edward is brutally punished for his transgression of gender norms and the presumption of effeminacy that haunted his reign. Royal masculinity may be socially constructed but the penalty for those who cannot conform is severe.

\section{Richard II and the Rise of the Favorites}

The historical Richard II came to the throne approximately fifty years after the death of Edward II. There are many parallels between their reigns, ${ }^{\mathrm{xl}}$ but Shakespeare chooses to primarily explore the roles of Richard's favorites on kingship. While Richard 
does not have the same intense emotional bond with his favorites that Edward had on Gaveston, these men shape the action of the play. Richard II begins with a dispute between Henry Bolingbroke and Thomas Mowbray that the king must adjudicate. Each nobleman accuses the other of being a traitor. After unsuccessfully trying to keep peace between the two men, Richard opts for a trial by combat to be settled later. When the appointed date arrives, however, the king calls off the combat before any blood is spilled. Furthermore, he decides to banish both men from the kingdom. Richard later defends his banishment of Bolingbroke by remarking that his favorites Bushy, Bagot, and Green helped him notice the exiled Bolingbroke's popularity with the common folk.

Ourself and Bushy, Bagot here, and Green

Observed his courtship to the common people;

How he did seem to dive into their hearts

With humble and familiar courtesy;

What reverence he did throw away on slaves,

Wooing poor craftsman with a craft of smiles

And patient underbearing of his fortune, As 'twere to banish their affects with him. Off goes his bonnet to an oyster wench;

A brace of draymen bid God speed him well

And had the tribute of his supple knee, With "Thanks, my countrymen, my loving friends"; As were our England in reversion his, And he our subjects' next degree in hope. (1.4.23-36)

This speech goes against the account of himself that King Henry gave in the introduction to this study. King Henry claimed that the populace admired him because he was rarely in their presence. King Richard claims that Bolingbroke is obsequious in courting favor and is apparently thinking that England is already his. Which account is to be believed? It is entirely possible that Richard's favorites have persuaded him to misconstrue circumstances. This is Bolingbroke's belief when he confronts them later in the play. The alternative is that Bolingbroke is not to be completely trusted. Whichever account of 
Bolingbroke is the correct one, Richard's disdain for the common people is prevalent in this speech. He calls them slaves and mentions several lower-class occupations while mocking the notion of Bolingbroke removing his hat and speaking to these people with courtesy. Strangely enough, this sneering from Richard is also at odds with King Henry's later account. According to the king, it was Richard who constantly curried favor with the commoners, so much so that they were sick of the sight of him. In shaping the characters of Richard II and Henry IV, Shakespeare gives the reader two very different accounts of the same events and the ambiguity is never fully resolved. What is clear is that Richard's opinions have been swayed by his favorites, a marker of effeminacy. In Henry IV's account of Richard, the skipping king is portrayed as exceptionally effeminate. In Richard's speech, however, he attempts to ward off accusations of effeminacy by displacing the behaviors onto his rival.

Richard's reasons for banishing a potential enemy are tossed aside with the news that John of Gaunt, the exiled Bolingbroke's father, is gravely ill. Here Richard begins to demonstrate an exceptionally ugly side to his personality. "Now put it, God, in the physician's mind / To help him to his grave immediately! / The lining of his coffers shall make coats / To deck our soldiers for these Irish wars. / Come, gentlemen, let's all go visit him. / Pray God we may make haste, and come too late" (1.4.59-64). His extreme callousness in the face of an elderly relative's suffering will continue into the next scene. John of Gaunt and his brother, the Duke of York, discuss the state of the realm. York advises Gaunt not to overtax himself in the hope that Richard will listen, "Vex not yourself nor strive not with your breath, / For all in vain comes counsel to his ear...it is stopped with other flattering sounds" (2.1.3-17). When Richard enters and begins 
speaking with disdain, Gaunt attempts to make him see the problems in his kingdom.

"Thy deathbed is no lesser than thy land, / Wherein thou liest in reputation sick; / And thou, too careless patient as thou art, / Committ'st thy anointed body to the cure / Of those physicians that first wounded thee. / A thousand flatterers sit within thy crown" (2.1.95-100). Richard, predictably, flies into a rage, and Gaunt is carried offstage to die.

His nephew gives the barest mention to his passing before revealing what he really wants.

The ripest fruit first falls, and so doth he;

His time is spent, our pilgrimage must be.

So much for that. Now for our Irish wars.

We must supplant those rough rug-headed kerns,

Which live like venom where no venom else

But only they have privilege to live.

And, for these great affairs do ask some charge,

Towards our assistance we do seize to us

The plate, coin, revenues, and movables

Whereof our uncle Gaunt did stand possessed. (2.1.153-162)

Richard commits several failures in this brief speech. The gendering of emotion in the early modern period could be somewhat paradoxical. Extremes of emotion at either pole were often gendered feminine. Consider the stereotypes of excessively doting mothers and wicked stepmothers. ${ }^{x l i}$ Moderation in all things, but especially in emotion was considered proper masculine behavior. Richard is showing himself to be a deficient human being who is incapable of showing proper emotion and respect. When he first hears of Gaunt's illness, he commits the sin of avarice instead of expressing concern for a close relative. He goes so far as to suggest that he would have had Gaunt executed if not for his sickness when the correct response would have been to excuse Gaunt's somewhat rash speech and remain calm. He is only concerned with using Gaunt's vast wealth to finance an ill-conceived war. His thoughtless and callous attitude is not befitting of a king. Kings must always remember that though they are divinely appointed, they must 
temper their power with reason and sensibility, a point which James frequently belabors in Basilikon Doron. Richard is riding roughshod over traditions and customs as well.

Gaunt's revenue rightfully belongs to his son, Bolingbroke. Though Richard attempts to skirt this niggling fact by suggesting that Bolingbroke's banishment renders his inheritance void, his nobles are not convinced. York points out that his actions will make him a powerful enemy, but Richard remains impenetrable to counsel. Gaunt is correct; the king is only interested in advice from those who flatter him. He attempts to placate the situation by placing his uncle York in charge of the kingdom while he is away in Ireland, but this too will backfire. The king's judgment is at fault from start to finish in this scene and he is unable to predict the consequences of his actions. Richard's effeminacy manifests itself not in an excess, as Edward's frequently does, but in a deficit of masculine and kingly qualities.

Though Richard is not as explicit as Edward in the expression of male same-sex desire, his followers are as destructive to his reign as Gaveston was for Edward. When Bolingbroke begins his hostile takeover of the kingdom, the reign of blood starts with Richard's favorites. He captures Bushy and Green and enumerates their crimes before sentencing them to death.

I will unfold some cause of your deaths. You have misled a prince, a royal king, A happy gentleman in blood and lineaments, By you unhappied and disfigured clean. You have in manner with your sinful hours Made a divorce betwixt his queen and him, Broke the possession of a royal bed, And stained the beauty of a fair queen's cheeks With tears drawn from her eyes by your foul wrongs. Myself- a prince, by fortune of my birth, Near to the king in blood, and near in love Till you did make him misinterpret me- 
Have stooped my neck under your injuries

And signed my English breath in foreign clouds,

Eating the bitter bread of banishment...

This and much more, much more than all this,

Condemns you to the death. (3.1.7-29)

Bolingbroke suggests an intimate relationship between the king and his followers, but he casts the blame entirely on Bushy and Green. The phrase "sinful hours" is deliciously euphemistic and whatever activities were performed during those hours drew Richard away from his queen. Unlike Edward, Richard does not have an heir, which is why Bolingbroke focuses so much on the queen and the royal bed. The historical Richard was married twice and produced no children. While Queen Isabel would have only been about ten years old during these events, thus explaining why they have no children, Shakespeare combines her character with Richard's late queen Anne of Bohemia, who

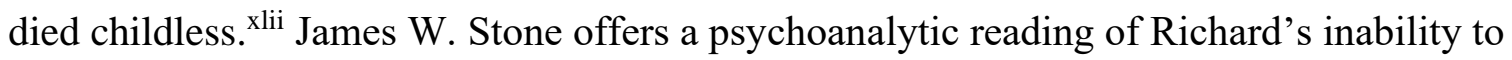
father a child. "Richard becomes more impotent and isolated as the play progresses...Isabel laments that Richard's abrupt departure for the Irish wars, without romantic leave-taking, has left his family unprovided for (heirless as well)" (Stone 53). In neglecting his sexual relationship with his wife, Richard has failed in one of his primary duties as a king. His presumed sterility is another marker of effeminacy for Bolingbroke to rebel against.

Bolingbroke draws on ideas of chivalry as he berates the men for causing the queen so much pain. He also insists, in a rather hurt manner, that he was loved by the king until Bushy and Green got in the way. This is an ambiguous remark. Is Bolingbroke merely hurt that his loyalty was misinterpreted or is he jealous of the attention that Richard showered on his favorites? The reading depends on the interpretation of actors. 
Rory Kinnear, who received a kiss from Richard before the aborted combat in 2012's The

Hollow Crown, delivered this line with a mixture of jealousy and regret. Bolingbroke

finishes his speech by outlining his suffering during banishment. The death of Bushy and Green takes place offstage but filmed productions like The Hollow Crown sometimes visualize the gory elements of the text. Kinnear watched their heads fall into the water with an expression halfway between horror and bloodlust. In indicting the favorites for their role in Richard's effeminate behavior, and by sentencing them to death, Bolingbroke sets himself up as a corrective to the decaying and effeminate brand of masculinity that is prevalent in Richard's court. From this moment in the text, support for Bolingbroke never flags, and the effeminate Richard is usurped.

Richard's dramatic nature and facility with language are on full display in the deposition scene. It is a masterful piece of rhetoric that represents a major draw for every actor who has ever played the role. The scene makes ample use of rhyming couplets, antitheses, and anaphora to stress the solemnity of the moment.

Ay, no, no, ay; for I must nothing be. Therefore no "no,: for I resign to thee. Now, mark me how I will undo myself. I give this heavy weight from off my head And this unwieldy scepter from my hand, The pride of kingly sway from out my heart. With mine own tears I wash away my balm; With mine own hands I give away my crown; With mine own tongue deny my sacred state; With mine own breath release all duteous oaths. All pomp and majesty I do forswear; My manors, rents, revenues I forgo; My acts, decrees, and statutes I deny. God pardon all oaths that are broke to me; God keep all vows unbroke are made to thee. Make me that nothing have with nothing grieved, And thou with all pleased that hast all achieved. Long mayst thou live in Richard's seat to sit, 
And soon lie Richard in an earthly pit.

God save King Henry, unkinged Richard says,

And send him many years of sunshine days. (4.1.200-220)

The speech has a ceremonial chanting quality, and it is a ceremony; or rather a reverse ceremony, as Richard undoes his majesty. Stone draws our attention to the first line. "“I know no I' is one possible transcription of the homophony in the first line of this passage, which can also be interpreted as the renunciation of the royal eye (I) as sign of the royal sun" (51). Since Richard no longer knows I, he does not know himself as a king or a man. In giving up his masculine identity, he is left in an effeminized position. The sense of reversal is evident in the consistent use of antithesis throughout the speech, as in "pardon" and "keep" and "sit" and "lie". Anaphora in the repeated use of "With mine own" and "God" marks the text as a proclamation. The insistence on the majesty and solemnity of the moment can often give the speech a religious aspect, which Richard is only too glad to admit. "God save the king, although I be not he, / And yet Amen, if heaven do think him me" (4.1.174-175). Religious opposition to the moment is provided in the form of the Bishop and Carlisle. "[He] vividly articulates the Elizabethan orthodoxy about the crime of usurpation...the bishop emphasizes both the sanctity of kingship and the sacrilege of the deed...[he] concludes with a prophecy, itself a religious idea, of the civil consequences if Bullingbrook supplants Richard on the throne" (McDonald and Orlin 445). The bishop's speech, which concludes that England will become "the field of Golgotha" (4.1.144), where Christ was crucified, prepares the audience for Richard's own use of religious imagery and comparisons to Christ. "Yet I well remember / The favours of these men. Were they not mine?" Did they not sometime cry 'All hail' to me? / So Judas did to Christ, but he in twelve / Found truth in all but one, 
I in twelve thousand none" (4.1.167-171). As Richard launches into his longer speech, he is presented as a martyr figure. In most productions, Richard wears a simple white robe and all his accessories are gone. He is now a passive figure. "As the passive object of a gaze that subordinates and subjects him, Richard is at the opposite pole from masculine control" (Stone 50). As Richard proceeds to divest himself of his kingship, he has only his command of language left, which he uses to run rhetorical circles around the other characters. Even as Richard loses all political power, he retains an incredible amount of power over the audience.

The spell is broken as Richard asks for a mirror to observe his no longer majestic face.

Give me the glass and therein will I read.

No deeper wrinkles yet? Hath sorrow struck

So many blows upon this face of mine

And made no deeper wounds? Oh flattering glass,

Like to my followers in prosperity

Thou dost beguile me. Was this face the face

That every day under his household roof

Did keep ten thousand men? Was this the face

That like the sun did make beholders wink?

Is this the face that faced so many follies,

And was at last outfaced by Bolingbroke?

A brittle glory shineth in this face.

As brittle as the glory is the face.

For there it is, cracked in an hundred shivers.

Mark, silent king, the moral of this sport.

How soon my sorrow hath destroyed my face. (4.1.275-290)

Richard's request for the looking glass is typically vain, but he uses to further manipulate his audience into a display of pity. He uses anaphora once again in the repeated "Was this the face" lines, with an additional layer. Richard uses the common trope of the flattering glass to connect with his former followers. The moment in which Richard smashes the mirror can create a variety of emotions. The gesture can be threatening, comical, or 
melodramatic. Sarah Fallon grabbed the scepter and brought it down on the mirror in a fit of rage, adding a threatening element to the scene. Despite Richard's best attempts to win pity, Bolingbroke is not moved. He merely ironically responds "The shadow of your sorrow hath destroyed / The shadow of your face" (4.1.291-292). Richard takes this as a poetic compliment about the depth of his hidden griefs, but Bolingbroke means it as a cutting comment on Richard's propensity to favor reflections over reality, and that his griefs have no true substance. Throughout the deposition scene, Richard is contrasted with Bolingbroke. Richard's flowing rhetoric contrasts with Bolingbroke's silences, and his vanity with Bolingbroke's plainness. The scene reaffirms the patterns of effeminacy that have been present in Richard through the beginning, but even as Richard loses everything, he remains a seductive and fascinating figure. Without his masculinity and without his kingship, the effeminate behavior for which he lost the crown in the first place, remains in full force.

The specter of effeminacy arises in an unusual place toward the end of Richard II.

The newly crowned King Henry asks for the whereabouts of his son.

Can no man tell me of my unthrifty son?

'Tis full three months since I did see him last.

If any plague hang over us, 'tis he. I would to God, my lords, he might be found. Enquire at London 'mongst the taverns there, For there they say he daily doth frequent With unrestrained loose companions, Even such, they say, as stand in narrow lanes And beat our watch and rob our passengers, Whilst he, young, wanton and effeminate boy, Takes on the point of honour to support

So dissolute a crew. (5.3.1-12)

Here Shakespeare notably diverges from historical record. The future King Henry V was between eleven and twelve years old at the time of Richard's deposition and was unlikely 
to have been frequenting taverns. On a practical level, this speech serves as the early modern equivalent of a theatrical trailer, as it hints of the future adventures of Hal, Falstaff and company in 1 Henry IV. In terms of gender concerns, Hal's behavior is already being expressed as effeminate, which is shorthand for displeasing to his father. This short speech will create a link with Act 3 of 1 Henry IV, as Hal stands before his father being lectured on his deficiencies and his unpleasant similarities to Richard. The figure of King Richard is not even dead, yet he and Hal are already connected. This speech illustrates the intertextual nature of the tetralogy and demonstrates how the ghost of King Richard and the specter of his effeminacy will haunt the subsequent plays.

\section{Edward II in Performance}

Edward II was seldom staged for centuries after its debut. Beginning in the 1960s, as homosexuality began to be decriminalized in England, the play experienced a renaissance of its own. Though directors attempted to emphasize the queer elements of the text, critics were not sold on this idea. In a review for a 1968 production of a Brechtian version of the play for the Old Vic, Peter Lewis of the Daily Mail writes "It is impossible to know whom to blame or praise for the mixed effects and non-effects of this mixed-up evening...Edward II [was portrayed as] a homosexual king” (Daily Mail 30 April 1968). A production for the Royal Shakespeare Company solidified the play's

reputation as a queer text. ${ }^{\text {xliii }}$ It marked the start of an illustrious stage career for Simon Russell Beale. Beale's unique voice shone through as Edward; his speeches possessed a remarkable sonorous quality that lent Marlowe's dialogue an operatic feel. Edward's passion for Gaveston (Grant Thatcher) was evident from the opening scenes of the play. 
The relationship between the two men was portrayed as genuine and not manipulative. Director Gerard Murphy did not shy away from depictions of physical affection, as Edward and Gaveston exchanged at least five kisses. Besides the touching and heartfelt depiction of same-sex love, the production's other strong point lay in the murder scene. The lights were kept dim, and the music made ample use of swelling strings reminiscent of Alfred Hitchcock's Pyscho. Finally, as the tension reached its height, the lights came up suddenly and shockingly on Edward being sodomized with the spit. Beale's scream was worthy of any horror film. The 1990 productions succeeded in both its depiction of a loving same-sex relationship and its depiction of the disastrous consequences that the relationship brings for Edward and Gaveston. Though the production is now regarded as an important interpretation, critical opinions in 1990 differed, and were often marked by homophobia. An anonymous review encapsulates the common attitude.

Murphy's production is permeated by a sense of overstatement with the result that Marlowe's play-ostensibly about the tragic conflict between political duty and personal obsession-has been transmuted into a kind of homoerotic black melodrama characterised by bulging cod-pieces and rough trade soldiers-cumscene shifters. Despite the sensitivity and heartfelt passion Simon Russell Beale puts into the performance after the demise of his lover Gaveston, the big tragic speeches are more queenly quiverings than kingly quakes. (Time Out October 1990)

The use of the word "queenly" is patently offensive here, yet it marks an all too common discomfort with depictions of male-male intimacy, that, as reviews for the RSC's Sejanus I discussed in Chapter Two demonstrated, have not dissipated in the $21^{\text {st }}$ century. Despite the doubts of the critics, Murphy's overtly queer sensual production paved the way for a major film adaptation as well as future stage production. 
Derek Jarman's 1991 film of Edward II goes out of its way to focus on queer elements. Gaveston delivers his opening speech on a bed with three other men, two of whom are engaging in intercourse behind him. Yet despite this explicit acknowledgment of queerness, the film struggles to capture real intimacy between Edward (Steven Waddington) and Gaveston (Andrew Tiernan). The two men dress alike, which hints at a relationship of equals, and thus at the presumption that the king is effeminized by this relationship. However, their costumes are very plain and lack the ostentatious elements that Mortimer complains Edward is bankrupting his kingdom for. There is a strange unwillingness to touch between Edward and Gaveston. Their tactile relationship is marked through choreographed dances. Gone is the gesture of exchanging miniatures.

The film desperately wants the audience to sympathize with Edward and Gaveston. After Gaveston's death, Edward leads a gay rights march with banners proclaiming, "Stop violence against lesbians and gay men" and "Gay desire is not a crime." However, it is especially difficult to sympathize with Gaveston as he is presented. Jarman astutely notes the differences in rank inherent in the text, with the nobles dressed as 1980s Margaret Thatcher cohorts and Gaveston sporting a punk aesthetic. The class struggle is undercut by Gaveston's behavior. His assault on the Bishop of Coventry is especially violent. The old man is stripped and forced to simulate oral sex on Gaveston. His cruelty to Isabella (Tilda Swinton) is also notable. In the "Madam, tis you that robs me of my lord" scene, he intrudes on her personal space and pretends that he wants to kiss her, laughing at her when she obliges. These scenes are extremely discomfiting and make it impossible not to agree with those who call for Gaveston's banishment. 
The film's ending is in keeping with Jarman's artistic vision as Edward seemingly survives. As the film reaches its climax, he hallucinates the death scene from the play, complete with a red-hot poker and screams of agony. A moment later, the murderer enters the cell again, tosses the poker into a pool of water, and kisses Edward passionately. The film finally ends on a long shot of young Edward, the new king. He has borrowed his mother's lipstick and earrings and dances on a cage where he has imprisoned his mother and Mortimer. His prisoners stare up at him through the bars, his mother almost adoringly and Mortimer in despair. The ending hammers home the notion that queerness cannot be contained.

A 2013 production for the National Theatre in London ${ }^{\text {xliv }}$ combined elements of Murphy's staging and Jarman's film in its presentation of the doomed king. Borrowing Jarman's use of modern dress, Gaveston (Kyle Soller) was dressed in skinny jeans and a leather jacket. He sported an American accent, an astute nod to the class struggles between Gaveston and the nobles. Here, as in Jarman's film, Edward (John Heffernan) and Gaveston egged each other on, playing football with the bishop's mitre. While Gaveston displayed true affection for Edward, he was more than capable of being manipulative. In a reversal of earlier portrayals, Isabella (Vanessa Kirby) was not presented as a tragic figure, but as a lecherous alcoholic. She attempted to kiss Gaveston and palm his groin, and he shoved her violently to the ground. The National Theatre's production's true strength was in its portrayal of the murder scene. Lightborne used the featherbed to give the king a more comfortable place to sleep and he sat next to him, stroking his back. The jewel Edward gave him was a miniature that Edward received from Gaveston earlier in the play. The token was a sign of Edward's implicit trust, after 
an intimate back and forth between the two men, which made the impending murder even more shocking. The production's final touch was having the same actor play both Gaveston and Lightborne, leaving the audience with the message that Edward's devotion to Gaveston led directly to his death. Kyle Soller put sinister poetry into his role as Lightborne, and as the murderer too was dispatched, he fell on the body of his erstwhile lover, the king.

The performance history of Edward II goes hand in hand with the gay rights movement, making it a unique object of study for a presentist viewpoint. Though it was first performed in 1592, its long history of censorship culminating in a twentieth century revival offers the text access to modernity. Stage productions and films of the play, while demonstrating considerable differences in approach, all aim to highlight the same-sex relationship and the presumption of effeminacy that are at the heart of Marlowe's text.

\section{Richard II in Performance}

Shakespeare's work receives far more productions than Marlowe's and Richard II has had many innovative performances over the centuries. An early performance rendered the play a controversial work when the earl of Essex paid for a performance of the work before his ill-fated rebellion. Legend has it that Queen Elizabeth saw too much of herself in Shakespeare's Richard and she is supposed to have said "I am Richard; know you not that?"’xlv Modern productions of Richard II have grappled with questions of masculinity and femininity in fascinating ways. A 2007 RSC production starring Jonathan Slinger emphasized the connection with Queen Elizabeth. Slinger, in a look reminiscent of drag, wore a distinctive red wig, pearl jewelry, and a costume that echoed Elizabethan portraiture. The favorites were dressed as typical Elizabethan courtiers. The 
pageantry and grandeur came to an abrupt halt after the deposition, when Slinger discarded the wig, revealing a bald head. This production used the framework of the Elizabethan court to illuminate the political climate of Shakespeare's day. Like Richard, Queen Elizabeth had many favorites and she could be fickle with her regard. The earl of Essex was a former favorite who grew discontented with the monarch, much as Bolingbroke does. Portraying Richard as a direct counterpart to Elizabeth visually addresses the idea of femininity. Elizabeth sometimes had to downplay the feminine and the costuming highlights the struggle to attain perfectly masculine behavior. Gender concerns were fully on display in one of the most well-known productions of the play, starring Fiona Shaw as Richard. Though the convention as men playing female roles was still accepted as an echo of Elizabethan stage practices, a woman playing a Shakespearean king was far more controversial. Critics were divided on who or what they saw in Shaw's performance. Elizabeth Klett points out that different critics saw "a dyke... a man-child... a homosexual boy... and a woman" (Klett 33) when they beheld Shaw on stage. The subversion of expectations in casting a woman as Richard can create confusion. However, this subversion neatly gestures at the struggles that Richard faces in the text; how will he express his own gender and how will it affect his grasp on power? With these questions in mind, I will consider three productions of Richard II, a made for television BBC Shakespeare production from 1978, and two productions from 2012, The Hollow Crown and an RSC production starring David Tennant. I will also consider a 2018 production for the American Shakespeare Center, starring Sarah Fallon as Richard. The BBC film is the most traditional of the three filmed versions. Derek Jacobi stars, and his king is the picture of effeminacy, with carefully curled hair and 
extremely elaborate costumes. Jacobi's Richard has a characteristic giggle when Richard is in control of a situation. Bushy, Bagot, and Green are also dressed luxuriously and all three wear visible eye makeup. In this production, the favorites set the tone for the aesthetics of Richard's court. When Richard discusses Bolingbroke's overtures to the commoners with his favorites, he is lying on a table receiving a massage while Bushy bathes nearby. Richard and Bagot are clad only in towels. The setting of the scene conjures images of sensual bathhouses, often viewed as effeminate and soft. The Hollow Crown uses a similar scene in Part Two of Henry IV as Hal and Poins relax in a sauna, again clad only in towels. At one point, Jacobi flips onto his back and starts delivering his lines facing the camera upside down. This unexpected move jolts the viewer into listening more carefully. Jacobi's display of openness and intimacy with his followers adds dimension to the scene, which is a negative depiction of Richard's jealousy and callousness. Jacobi expresses these qualities in the scene with John Gielgud's Gaunt, which is marked by impotent rage and giddy greed. This production offers a clear depiction of Richard's struggle with effeminacy and its effects on his power.

With Deborah Warner's 1995-96 production of Richard II and the BBC television production of 1997, starring Irish actress Fiona Shaw, cross-gender casting and androgynous costuming create a character that (British) audiences were distinctly uncomfortable with. Elizabeth Klett's analysis of the production draws on critical response and she argues that the "sampling of critical responses indicates that the production was dangerous because it challenged the boundaries of legitimate or acceptable choices in performing Shakespeare on the British stage" (31). The simple fact of having a female-bodied person play Richard excited some reviewers, who found that 
the choice revealed new dimensions of the character, while others painted over their sexism with complaints about Shaw's voice and body language. In staging Richard's effeminacy, this production creates a king who dances rapidly across the boundaries of gender. Though Warner downplayed the implications of casting Shaw in the popular press, she revealed her motivations clearly in academic interviews. "I wanted everybody who came across Richard to have a great big problem when they met this person who must be male through virtue of being a king, yet who looked like a woman and was effeminate" (qtd. in Klett 32). Warner's comments explicitly link Richard with effeminacy, and this concept is evident in many of the choices Shaw makes. Her lyrical voice frequently soars in the higher register, echoing Simon Russell Beale's Edward. Shaw's androgynous costuming complicated her performance of gender and effeminacy, wearing bandages to keep her legs tight and create a more masculine walk (Klett 38) while maintaining a feminine giggle much like Jacobi's and later, Whishaw's. With a lack of emphasis on finery, Richard's effeminacy is primarily conveyed through a lack of kingly behavior. Shaw's Richard can be singularly callous, particularly to Queen Isabel. Richard speaks to Isabel in a loud, over-exaggerated voice while Bushy, Bagot, and Greene cackle with glee. The king implies that Isabel does not speak English well, which is contrary to the text, and has the effect of humiliating the queen despite their touching farewell scene. This moment reinforces Bolingbroke's claim that the favorites have corrupted Richard with their sinful hours. Richard is also very clearly partial to Bolingbroke in the early scenes, until the aborted combat forces his hand. Shaw's Richard is initially all smiles for Bolingbroke and favors him with intimate kisses until his inevitable betrayal. In the television production, the final shot is of the new King 
Henry IV kissing Richard's corpse. This choice provides a new tragic outlook on the play. With the relationship between Richard and Bolingbroke marked by queer sexuality, as Klett argues, the viewer is left with the impression that the new king has achieved this position only because he is successful at "playing straight" without any hint of effeminacy.

With 2012's The Hollow Crown, also produced by the BBC, the depiction of effeminacy is much like the 1978 production. Ben Whishaw echoes Jacobi in his giggle and his curly hair recalls Jacobi's king. Richard is splendidly dressed, though in a color palette of primarily white, cream, and gold in contrast to the reds of the 1978 production. Though Whishaw is clearly in the grip of his favorites and he consults them after the aborted combat, he displays a slight paranoia that indicates that he may not fully trust them. Despite his possible lack of trust, Whishaw's Richard is a very tactile king. He caresses Bolingbroke's face tenderly before the combat. This production also emphasizes the small acts of intimacy that are bestowed on kings, showing servants wash Richard's hands and dress him. Richard's spendthrift ways are also abundantly clear. His tent for the tournament is spectacularly furnished and inhabited by a pet monkey. Rupert Goold's direction also emphasizes the religious elements of the text, sometimes coming off a bit heavy handed. Crucifixes are frequent visual elements. In a scene with no dialogue that blends the religious and the queer, Richard watches one of his favorites paint a depiction of Saint Sebastian. Richard approaches the beautiful young boy modeling Sebastian and touches the false blood on the boy's chest. At this point, his queen interrupts him, much to his chagrin. The Saint Sebastian motif returns at the end of the performance. In contrast to the 1978 production, which presents Richard's murder exactly as written, the 
Hollow Crown makes significant changes. Richard is clad only in a loincloth and he is murdered with crossbows, which forms another visual representation of Saint Sebastian. Goold's point is all too clear; while it may be tragic, Richard's effeminacy has led him here.

Greg Doran's 2012 production starring David Tennant goes further than either of the previous two in its depiction of same-sex intimacy. For Derek Higginbotham, the relatively plain costuming of this production was a failure, as it did not convey the wastefulness of Richard's court. ${ }^{\text {xlvi }}$ While his point is astute, the production was much more focused on Richard's emotional state and the effeminacy resulting from his actions. A visual representation of effeminacy is also in effect with Tennant's hair; which is long and flowing. His hair is longer than any other male character's. Just as Whishaw was a tactile king, Tennant is as well. He is physically intimate with many, including the favorites, whom he is clearly seen taking advice from. Before the combat, Richard kisses Bolingbroke almost on the lips in a Judas kiss moment. The kiss demonstrates Richard's comfort with same-sex intimacy but also reminds those who have read the play that he is about to banish Bolingbroke. The level of intimacy heightens throughout the play as his favorites, not ordinary servants, help to undress the king. Doran's production emphasizes Richard's feelings not just for Bushy, Bagot, and Green, but for his cousin Aumerle. Richard saves most of his intimate gestures for Aumerle. In Act 3, Scene 4, as Bolingbroke approaches to discuss terms of Richard's surrender, the king notes "Aumerle, thou weep'st, my tenderhearted cousin" (160). At this point, the action comes to a halt as Richard silently attempts to cheer his cousin up by smiling, caressing his cheek, and placing the crown on Aumerle's head. Aumerle's tears stop and he returns 
Richard's affections, staring deep into his eyes. Then the two share a long, tender kiss on the lips. This long moment is exceptionally moving, and it gives Richard the strength to go into the confrontation with Bolingbroke. Aumerle is presented not as a flatterer who wastes the king's time, but as someone who truly loves Richard and cares for him. This decision adds weight to Aumerle's attempted rebellion against the new King Henry.

\section{The Blackfriars' Richard and the Actors' Renaissance Season}

The 2018 American Shakespeare Center production during the Actors'

Renaissance Season opted for a different portrayal of both Aumerle and Richard. Sarah

Fallon played the king. ${ }^{x l v i i}$ Due to the special nature of the Actors' Renaissance Season, Fallon had unprecedented control over artistic decisions. The Actors' Renaissance Season takes place every winter at the American Shakespeare Center. The goal is to delve even deeper into early modern staging conditions. Plays are staged collaboratively, without the help of a director. In each production, the leading actor takes on a directorial role and makes staging decisions. Rehearsals are held for a much shorter period, and early performances make use of an offstage prompter in the event of what the actors refer to as "textual instability." Since the Blackfriars space uses universal lighting, the audience is always visible to the actors and the actors can obtain easily obtain visual feedback from the audience. Fallon was eager to discuss what drew her to the character of Richard. "The language is the first thing that attracts me to the role. The beauty of his poetry is what really gets me. I feel like he gets more poetic as he loses more. As he's losing power, I feel like his language gets more poetic and introspective. The way that Richard uses language in that [deposition] scene is to maintain control." For Fallon, Richard's character arc deals with his complete loss of power, which is destabilizing as "He's 
known power his whole life. He's failing from the start." She wanted to create a selfassured monarch who is comfortable with power and has had this role since childhood, but still makes mistakes. Fallon has performed in Richard II previously, as the queen. Her experience in that role made her eager to draw attention to a part that is often neglected. "The first time they speak to each other is this beautiful goodbye. I wanted to try to establish a relationship early on but it's tough when you don't have the words. I am not playing Richard as homosexual because in the text I don't think there's anything for me that says that". Fallon got around the problem of a lack of dialogue by incorporating gesture into her scenes with the queen, with Richard taking her hand as they descend from their thrones. Fallon and Lauren Ballard were passionate in their farewell scene, which caused a palpable emotional response from the audience. Fallon's care to not exclude the queen brought out a different side of Richard that is not often touched on, and the nuance was admirable. As far as the question of Richard's sexuality, Fallon is correct that the text is not overt, as Marlowe's is in its depiction of Edward and Gaveston. Richard represents a much more ambiguous figure. It is the task of the actor and the director to draw their own conclusions from close reading. How intimate is Richard with Aumerle and his followers? What have their "sinful hours" consisted of? Most of all, how will a certain production depict Richard's effeminacy?

All four productions of Richard II admirably address the issue of effeminacy. In all four, Richard is visually contrasted with Bolingbroke. The visual contrast is particularly effective in The Hollow Crown, with Ben Whishaw's slender Richard opposed by Rory Kinnear's rugged, bearded Bolingbroke. Sarah Fallon's gold clothing and braided red hair created an excellent contrast with David Anthony Lewis' tall, stocky 
figure. Richard is a man of many faults, chief of which is effeminacy. However, truly problematic effeminacy is shown not through rich clothing, or jewels, or even same-sex intimacy, but through failing to display the masculine qualities of judgment, restraint, and respect.

A reading of England's effeminate kings offers a nuanced understanding of how effeminacy operates in conjunction with kingship. The examples of Edward II and Richard II illustrate the dangers of being perceived as effeminate. Neither monarch retains the throne and neither monarch holds firm to the precepts of masculine government as articulated by writers like James I. Reading Marlowe and Shakespeare's plays together offers a unique understanding of medieval monarchy and authoritative government, as well as the pitfalls when these monarchs and governments begin to break down. Though Edward and Richard do fail, and part of their failure can be traced back to behavior that is singled out as effeminate, in reading both plays the politics of the $14^{\text {th }}$ century are more prevalent than sexual concerns. If we consider Edward and Richard as points on a timeline, with other crises of the $14^{\text {th }}$ century such as the Black Death in between, the instability of their reigns becomes a large part of one hundred years of upheaval. After so many years of instability, the anxious King Henry IV's lecture to his wayward son Prince Hal becomes more than just the angry words of a father who can't understand his son. Henry's position is still far from certain; rebels are gathering in the North, and his son can't be bothered to sit in on council meetings. King Henry's worry that Hal is becoming too much like "the skipping king" is in this context less a matter of intolerance or of his own personal dislike for Richard than a legitimate worry that the 
government of England stands in danger of failing yet again. Effeminacy here is not just a matter of a preference for fine clothing, but a threat to national security.

\section{Conclusion}

Both Edward II and Richard II represent a dramatist's attempt to construct medieval history for popular entertainment. There was also the danger that their discussions of these effeminate kings could be taken for criticism of current monarchs. ${ }^{\text {xlviii }}$ Therefore, performance has always been vital for these texts and it remains vital for the presentation of effeminacy. In productions of Edward II, the audience is privy to the extent of Edward's clinging devotion for Gaveston as well as the violation of Edward's body in the murder scene. The poetic constructions of Richard's speeches are a delight on the page or the stage, but performance aids in illuminating Richard's patterns of effeminacy. Consider Bolingbroke's accusation that the favorites tempted Richard with their "sinful hours." The reader has only Bolingbroke's word for this assertion, but a performance can gloss what this phrase might mean and reveal the extent of Richard's behavior. In the $1978 \mathrm{BBC}$ production, this includes Richard relaxing with the favorites in an eroticized sauna. In the 2012 production, Richard's favorites are continually close to him and often touch him. The skipping king that Henry IV speaks so slightingly of becomes much more visible through the medium of performance. 


\section{Chapter 4: Love's Labour's Lost and As You Like It: Masculinity and Painful Subjugation in Comedy}

How is effeminacy presented when it is played for laughs? This final chapter examines two Shakespearean comedies, As You Like It and Love's Labour's Lost and analyzes how the treatment of masculinity differs when presented in a comic light. The aristocratic male characters in these comedies put themselves through various trials for love. These include Orlando's mock wooing of Ganymede in As You Like It (though Orlando is a special case since his elder brother and guardian has failed to instruct him in the manners of the aristocracy) and the trial of celibacy that the King of Navarre and his lords are forced to undergo at the end of Love's Labour's Lost. I consider the nature of masculine desire, possibilities for homoeroticism and the various methods of subjugation the characters go through. Performance is particularly important when discussing comedy since the genre so often depends on the visual medium, whether through sight gags or jokes that do not translate well on the page. I will primarily discuss $21^{\text {st }}$ century theatre productions of both plays, along with Kenneth Branagh's filmed version of Love's Labour's Lost and Cheek by Jowl's seminal all-male production of As You Like It from 1991/95. I argue that in the comedies, effeminacy is a far cry from the danger presented in the histories and Roman plays; rather, by being played for laughs, effeminacy becomes a stepping-stone on the path to adult masculinity.

It is relevant to compare the romance tropes of early modern literature with today's romantic comedies since there has been such a marked cultural shift in how we perceive love and romance. Romantic comedy remains a popular genre, with 
Shakespeare's comedies still frequently performed and filmed. Many viewers associate grand romantic gestures with these kinds of comedies; often the grand gesture pays off and the man is rewarded with a romantic relationship. Humiliation is also a large part of romantic comedy. In this, our modern films follow their early modern forebears.

However, there is sometimes a misogynistic undertone in how men in love are treated. Despite these cultural negatives, romance is still viewed as a valid pursuit and dating has been elevated to an art form. Dating coaches and dubious "pick up artists" "xlix exist to teach men how to land the perfect female partner. However, in the Renaissance model, love itself could be a dangerous excess. If not properly checked, men in love stood the risk of performing in non-masculine ways. It is this framework that Romeo references when he proclaims, "O sweet Juliet, / Thy beauty hath made me effeminate / And in my temper softened valor's steel" (Romeo and Juliet 3.1.112-114). Conduct books of the era, as referenced in Chapter 1, cautioned young men to avoid sinking too deeply into love's excesses, while the stage comedies showed men undergoing various kinds of humiliation for love.

\section{Love's Labour's Lost: Delayed Gratification}

Love's Labour's Lost is one of Shakespeare's earliest comedies, with a likely performance date of 1593. It is also one of his least conventional comedies. Were it not for the overwrought oaths of love and trials that the beleaguered men undergo, the reader might not identify the play as a romantic comedy. As Peter Holland notes, "remarkably, not a single character begins or ends the play married...Marriage at the end of Love's Labour's Lost is a consummation of courtship and wooing that is not only postponed but also possibly never to be reached" (Pelican Shakespeare 209). Students in undergraduate 
Shakespeare classes may be taught that Shakespeare's comedies end in marriage and his tragedies end in death, but this play ends with a death and no marriage, not for a year at the very least. As Berowne notes in a metatheatrical moment, "That's too long for a play" (5.2.862). This notoriously ambiguous ending is one of the likely reasons why Love's Labour's Lost has for centuries been performed far less frequently performed than As You Like It. Despite these two objections to the play, Love's Labour's Lost is having a renaissance of its own. The battle of the sexes in the play, in which the women are more skilled debaters who must instruct the men, and the ambiguous ending's postmodern sensibility have begun to appeal to modern audiences. I will discuss two stage productions from the past five years as well as Kenneth Branagh's 2000 film.

The play begins with a theme that will carry throughout the action: making oaths. The situation seems far removed from a standard romantic comedy. The King of Navarre has convinced three other lords, Berowne, Dumaine, and Longaville, to sequester themselves in his court to study.

Therefore, brave conquerors- for so you are That war against your own affections And the huge army of the world's desiresOur late edict shall strongly stand in force: Navarre shall be the wonder of the world; Our court shall be a little academe, Still and contemplative in living art...

Your oaths are passed; and now subscribe your names, That his own hand may strike his honor down That violates the smallest branch herein. If you are armed to do as sworn to do, Subscribe your deep oaths, and keep it too (1.1.7-23)

Navarre's speech assigns a grandiose quality to his plan; he positions the other lords as brave conquerors who will do battle with the hedonistic delights of the wider world. The oaths that the lords have already sworn, combined with the paper that they are about to 
sign creates the impression of a serious enterprise. It is only when Berowne, in his masterful cynicism, begins to push back against the plan that it cracks under the pressure. We learn that the men will not only study ceaselessly, but they must fast, sleep three hours a night, and under no circumstances consort with women. The extremity of the provisions, combined with the ludicrous punishments for breaking the rules (women approaching Navarre's court stand in danger of losing their tongues) creates the impression that these oaths are as fragile as the paper they are written on. In the opening scene of Love's Labour's Lost, Shakespeare mocks the austerity of single-sex environments of learning, such as universities, and reveals the inherent immaturity in Navarre's endeavor. Upon reading the article prohibiting the men from talking with women, Berowne points out that "This article, my liege, yourself must break; / For well you know here comes in embassy / The French king's daughter...Therefore this article is made in vain, / Or vainly comes the admired princess hither" (1.1.130-136). "What say you, lords? Why this was quite forgot?" (137) Navarre moans in reply. The validity of the oath has been drastically undercut now that we see that it interferes with responsibilities of state. Much of the action of the play will focus on the contrast between the men's increasingly vanishing determination to keep their oaths and questions over whether they are worth keeping in the first place. Berowne pointedly questions the "necessity" of having the princess and her train at court despite their oaths. Bruce Smith takes Berowne's quip as an example of a kind of heterosexual imperative in the play. ${ }^{1}$ I reject this claim, since the play's ending belies the assumption that the natural order of a comedy ends with marriage. On the surface, Berowne's claim establishes the primacy of sexual desire, but it also illuminates the human tendency to confuse want and need. 
Berowne's argument is a concrete instance of the earnest but immature masculinity inherent in effeminacy on display in the first scene of this comedy.

Shakespeare continues his put-down of aristocratic masculinity through the Spanish (and therefore Other) figure of Don Armado, who is under the tutelage of his pageboy Moth. Melodie Garcia points out that in addition to offering a parody of the Spanish after the defeat of the Armada, Shakespeare is likely referring to the court figure of Antonio Perez, an extravagant braggart and royal name-dropper. ${ }^{\text {li }}$ There is an instant role reversal in Armado's interactions with Moth; the youth is more rhetorically gifted than his master and Armado uses him as a kind of encyclopedia. Valerie Billing also notes potential for queerness in the relationship between Armado and Moth: "The Spanish braggart Armado and his young page Moth's first scene together...dramatizes the erotic friction between Armado and Moth through talk of physical size and social stature. Armado...expresses intimate fondness for Moth as, specifically, a small dependent boy" (111). Armado is represented as effeminate through his affections for both a lower ranking boy and woman. He begins the play under love's influence, and he is aware that his emotions run contrary to the demeanor that is expected of a man of his rank.

Armado: I will hereupon confess that I am in love; and as it is base for a soldier to love, so I am in love with a base wench. Comfort me, boy. What great men have been in love?

Moth: Hercules, master.

Armado: Most sweet Hercules! More authority, dear boy, name more; and, sweet my child, let them be men of good repute and carriage.

Moth: Samson, master- he was a man of good carriage, great carriage, for he carried the town gates on his back like a porter, and he was in love. Armado: O well-knit Samson! Strong-jointed Samson! I do excel thee in my rapier as much as thou didst me in carrying gates. I am in love too (1.2.56-105) 
Armado finds his love problematic for two reasons; first, that his excessive emotions are unbecoming of a soldier (Antony's men use this reasoning to dismay over his relationship with Cleopatra) and a man approaching middle age, and second, that the object of his affections is a woman of much lower rank. He turns to Moth as a human conduct book who will provide with him examples of great men in a similar situation. What Moth conveniently forgets to mention is that the love stories of Hercules and Samson ended in disaster. ${ }^{\text {lii }}$ Furthermore, both the great men Moth mentions were subjugated by women in various ways. Samson is famously emasculated by Delilah, and Hercules (as discussed in Chapters 1 and 2) performs the female occupation of spinning for Omphale. Though Moth does not directly mention the effeminizing nature of love, it is clearly on his mind by the examples he cites, cementing the image of Armado as another man effeminized by love in the audience's mind. Though Moth cites his examples rather pointedly, Armado does not understand the implied lesson. "Most sweet Hercules! Strong-jointed Samson!" In many ways, Armado is seen as a foolish figure by the other characters in the play, and his blindness to Moth's true meaning cements his position as a comic figure for the other characters to mock.

Much like Navarre and his three lords, Armado is initially concerned with his oath, but he rationalizes himself out of it.

I do affect the very ground (which is base) where her shoe (which is baser) guided by her foot (which is basest) doth tread. I shall be forsworn (which is a great argument of falsehood) if I love. And how can that be true love which is falsely attempted? Love is a familiar. Love is a devil. There is no evil angel but Love...Adieu, valor! Rust, rapier! Be still, drum! For your manager is in love; yea, he loveth. Assist me some extemporal god of rhyme, for I am sure I shall turn sonnet. Devise, wit! Write, pen! (1.2.160-176) 
Armado draws on the precedents referenced earlier in the scene to not only excuse his love for Jaquenetta but his oath as well. In his moralizing on the temptations of love, Armado echoes stern conduct books. Just as Romeo exclaims that Juliet's beauty has made him effeminate and paralyzed his sword, Armado bids a gay farewell to the trappings of his position, under the assumption that they cannot exist in the same space as love. His new tools are his wit and his pen, which he will use to craft sonnets of love.

Writing a sonnet is viewed as entirely antithetical to fighting a battle and a soldier must give up his warlike masculinity while he is under the influence of love. liii Armado's brief soliloquy sets up the conflict between love and celibacy that will ensnare Navarre and his lords. The mention of a sonnet will come full circle as Berowne and the others read their poor attempts aloud in 4.3, discovering that they have all been forsworn. It may be easier for an audience member to laugh off a figure like Armado, who, despite his high rank, is presented as a comic foreigner to the gentlemen of Navarre rather than a serious aristocrat. When Navarre, Berowne, and the others fall prey to the same temptations, their perceived effeminacy is harder to ignore.

It is Berowne who begins to articulate the problems with love. He shares some similarities with a slightly later Shakespearean character; Benedick from Much Ado About Nothing as he soliloquizes his disgust with himself for falling in love.

And I, forsooth, in love!

I that have been love's whip, A domineering pedant o'er the boy, Than whom no mortal so magnificent. This wimpled, whining, purblind, wayward boy, This signor-junior, giant-dwarf, Dan Cupid... And, among three, to love the worst of all, A whitely wanton with a velvet brow, With two pitch balls stuck in her face for eyes. Ay, and by heaven, one that will do the deed, 
Though Argus were her eunuch and her guard...

Well, I will love, write, sigh, pray, sue, groan. (3.1.170-201)

Berowne's use of language to describe Cupid furthers the perception that love is effeminizing. Cupid is called boy twice, and the words wimpled and whining would more appropriately describe a convent schoolgirl than a male deity. Valerie Billing uncovers a queer potential in this scene. "Berowne admits his love by not actually talking about Rosaline, but by casting himself as a slave to a simultaneously miniature and gigantic Cupid" (109). Berowne's scornful attitude towards Cupid echoes what we heard from Armado earlier in the play, and his attitude towards his love goes further. Armado mentions Jaquenetta's baseness due to her lower rank, but Berowne puts down Rosaline's appearance and accuses her of being promiscuous with no apparent evidence. It is a tactic familiar to modern readers who have seen men scorn the appearance of women who have rejected them. This ugly impulse from Berowne marks one of the undercurrents of cynicism running through Love's Labour's Lost. Both Love's Labour's Lost and As You Like It deal with similar themes of humiliation for love and the effeminizing nature of desire, but As You Like It retains the tone of a romantic comedy while Love's Labour's Lost operates in a more satirical vein. Berowne ends his speech with a series of verbs common to all lovers: love, write, sigh, pray, sue, groan. The performance of these actions leads to a path where men appear passive at best and outright ridiculous at worst. That the second action Berowne mentions is writing is not coincidental; we have already seen Don Armado's determination to write a sonnet and Berowne echoes the presumption that writing love poetry and feeling the emotion of love go hand in hand and that both of these are riddled with effeminacy. 
Love's Labour's Lost provides both a comic payoff and a clear discussion of the effeminacy of love as Berowne hides and hears each of the lords confess his love with an overwrought sonnet. Berowne encourages Longaville with an aside: "O, rhymes are guards on wanton Cupid's hose; / Disfigure not his slop" (4.3.54-5). His quip confirms that love and poetry are close companions as he imagines rhymes to be the trimmings of Cupid's costume. Navarre, unaware that he has been overheard by Berowne, reveals himself to chastise Longaville and Dumaine for breaking their oaths: "I heard your guilty rhymes, observed your fashion, / Saw sighs reek from you, noted well your passion. / 'Ay me!' says one; 'O Jove!' the other cries” (135-7). The king indicts the lords for performing effeminate love, with sighs, passion and complaints to a higher power. Berowne, however, cannot resist exposing Navarre as a fellow lover.

But are you not ashamed? Nay, are you not? All three of you, to be thus much o'ershot? You found his mote; the king your mote did see; But I a beam do find in each of three. O what a scene of fool'ry I have seen, Of sighs, of groans, of sorrow, and of teen! O me, with what strict patience have I sat, To see a king transformed to a gnat; To see great Hercules whipping a gig, And profound Solomon tune a jig, And Nestor play at pushpin with the boys, And critic Timon laugh at idle toys! (155-66).

Berowne uses his assumed virtue to berate the other lords, and in his recriminations, he draws on the theme of love as effeminizing. He enumerates the sighs, groans, and tears that he has heard before presenting them with the image of powerful men subjugated by love and engrossed in childish behavior. Hercules makes a reappearance here, playing with a child's top. The posture of a child is also marked as effeminiate. In this speech, the men are emasculated not by the actions of women, but by their own folly. The scene 
builds on humiliation as Berowne's own poor attempt at a sonnet is discovered.

Unmasked as a lover, Berowne assumes a role as the leader of the lovers, and they triumphantly go to woo the women.

The humiliation of the male characters reaches a fever pitch in the Russian episode of 5.2. Navarre and the lords visit the ladies' tent disguised as Russians. The princess and her ladies receive them masked, having switched love tokens to confuse their potential suitors. Though the episode is a short part of a very long scene, it brings the courtship theme to a climax as the ladies engage in comic banter with the men. Despite the lords' carefully calculated plans, the women turn their backs and address them mockingly. Their response is in keeping with their later claim that they did not perceive the lords' courtship as serious. The ludicrous nature of the spectacle prompts a reader, or an audience member, to agree. Navarre and the lords' attempt at romance is riddled with hackneyed tropes and more bad poetry that the ladies interpret as nothing more than idle jesting. It is only after the tonal shift that comes with the entry of Marcadé announcing the king's death that the ladies take on the role of tutors for their would-be suitors. In a play full of words, the princess and her ladies teach the men that serious masculine courtship comes from deeds, not words. In a somber rehearsal for the more lighthearted scenes of As You Like It, the women of Love's Labour's Lost instruct their hearers in what makes a serious relationship and the difference between love and infatuation. In both comedies, the women have agency while the men undergo a process of effeminization in being put under the tutelage of women. However, this process is not negative, but necessary, as it transforms the male characters from immature suitors into adult male lovers. 


\section{As You Like It: Love is a Madness}

Shakespeare's 1599 comedy As You Like It shares many similarities with its predecessor, Love's Labour's Lost. Foremost is the pastoral setting of both plays, which builds on a literary tradition from Sidney to Marlowe. Except for the early scenes at Duke Frederick's court, the action of As You Like It takes place in the forest of Arden. A more surprising link between the comedies is their performance of literary criticism. Both plays feature bad poems from immature suitors, and a literary discussion of what makes them bad. As You Like It builds on the scene with Berowne mocking his fellows' verse with Rosalind and company pointing out in technical detail the flaws in Orlando's composition. The importance of verse-making and verse-critiquing relies on the assumption that writing love poems is synonymous with the emotion of love itself, and that the process is a feminine one. ${ }^{\text {liv }}$ Another primary link between the two plays is the importance and agency of the female characters. The Princess of France and her ladies are tutors to the hapless Navarre and the lords, while Rosalind is at the center of her play and her love tutelage of Orlando provides the comedy with its main plot.

As You Like It begins with Orlando's displeasure with how he is treated by his elder brother. Orlando's status as an aristocratic gentleman is called into question by Oliver's mistreatment.

For my part, [Oliver] keeps me rustically at home, or, to speak more properly, stays me here at home unkept. For call you that 'keeping' for a gentleman of my birth, that differs not from the stalling of an ox? His horses are bred better...But I, his brother, gain nothing under him...He lets me feed with his hinds, bars me the place of a brother, and, as much as in him lies, mines my gentility with my education. (1.1.6-21)

Oliver's mistreatment of his younger brother is abusive, but Orlando's chief complaint is that he is not being treated according to his rank. Orlando explodes in a fit of righteous 
anger. "You shall hear me. My / father charged you in his will to give me good / education. You have trained me like a peasant, obscuring and hiding from me all gentlemanlike / qualities" (1.1.65-9). In his ignorance of gentlemanlike qualities, Orlando is at risk of performing effeminate behavior, through no fault of his own. Though Oliver privately complains that his brother possesses aristocratic qualities without teaching, Orlando's lack of a proper education sets him up to be schooled by Rosalind, as the men of Love's Labour's Lost are taught by the princess and her ladies.

Rosalind's instruction of Orlando can only happen after she is in disguise in the forest of Arden. As with Shakespeare's other cross-dressing comedies, the pretext for Rosalind to dress in men's clothing can seem flimsy. She offers only her height as a reason. Even flimsier is the name she chooses for her male alias. "I'll have no worse a name than Jove's own page, And therefore look you call me Ganymede" (1.3.131-2). If Rosalind wishes to pass as a man unquestioned, the name Ganymede will not help her with that goal. Unlike the heroines in other cross-dressing comedies, Rosalind's alias is specifically associated with male homoeroticism. ${ }^{\text {lv }}$ The name is an odd choice that apparently only serves to highlight Rosalind's feminine qualities under the disguise. Yet it is instructive to remember that the role was initially played by a boy actor. What did audiences see when they beheld the character of Rosalind on stage? A common element in theatrical opposition is the fear of sexual immorality. Anti-theatricalists agree that men will be seduced by the spectacle of men in women's attire but there is considerable disagreement over whether these impressionable men will desire the female illusion or the boy beneath the gown. As noted in the Introduction, John Rainoldes was certain that cross-dressing was a slippery slope that led to sodomy while Philip Stubbes was more 
concerned that these illusions would lead men to seek out prostitutes (Orgel

Impersonations 28-29). The anti-theatricalists were panicking about boys becoming women through wearing female dress and men becoming drawn to these women in young masculine form. Women were dangerous, and so were their clothes. While the character of Rosalind spends very little of the action of the play in female attire, her choice of a male alias hints at both Rosalind's gender beneath the Ganymede disguise and the boy actor's gender underneath his costume.

Though this study is chiefly concerned with aristocratic masculinity, it is necessary to touch on the character of the shepherd Silvius. Rosalind/Ganymede and her companions overhear Silvius' laments to the older shepherd, Corin.

Silvius: O Corin, that thou knew'st how I do love her! Corin: I partly guess, for I have loved ere now.

Silvius: No, Corin, being old, thou canst not guess, Though in thy youth thou wast as true a lover As ever sighed upon a midnight pillow. But if thy love were ever like to mine, As sure I think did never man love so, How many actions most ridiculous Hast thou been drawn to by thy fantasy? Corin: Into a thousand that I have forgotten.

Silvius: O, thou didst then never love so heartily! If thou rememb'rest not the slightest folly That ever love did make thee run into, Thou hast not loved.

Or if thou hast not sat as I do now, Wearying thy hearer in thy mistress' praise, Thou hast not loved Or if thou hast not broke from company Abruptly, as my passion now makes me, Thou hast not loved.

O, Phebe, Phebe, Phebe! (2.4.20-40)

In this exchange with Corin, Silvius represents the typical picture of a youth effeminized by love. Angela Thirwell notes that Silvius epitomizes the lovesick swain (71) in his 
histrionics, a position that can very easily slide into effeminate behavior. Indeed, Silvius feels little removed from any teenager who insists that his love is unique and that no one could possibly understand it. As Silvius rather bluntly notes, Corin is "old" and therefore his days of love are behind him. In his insistence that the old Corin cannot understand his passion and in his reaction to Corin's sentiments, Silvius hints at the obsessive, but sometimes ephemeral nature of love. Corin freely admits that he has forgotten the "actions most ridiculous," perhaps not unlike the Russian masque in Love's Labour's Lost, that he has performed in the name of love. For Silvius, every ridiculous action is fresh and painful, but he takes it as a sign of true love, whereas Corin's maturity allows him to realize that the ridiculous actions of fantasy are not the true substance of love. Silvius unwittingly acts as a mirror for Rosalind. "Alas, poor shepherd! Searching of thy wound, / I have by hard adventure found mine own" (2.4.21-22). The extremes of Silvius' emotions are natural to Rosalind as she is still in a state of infatuation with Orlando. It is only in disguise in the forest that she can interact with Orlando on his level and achieve a deeper understanding. Just as Orlando and Rosalind undergo a journey to understand love, Silvius transforms from this histrionic figure to a slightly more reserved figure in Act Five. Like Orlando, Silvius undergoes a process of effeminization that leads to the desirable result of maturity. As Thirwell argues, "Silvius launches into verse to describe what his passionate version of courtly love feels like. It was an accepted convention of pastoral for chivalric love to be expressed by a shepherd" (85). This moment recalls the eclogues of Sidney's Arcadia and Silvius' prescriptions "It is to be all made of faith and service... all made of fantasy, / All made of passion, and all made of wishes, / All adoration, duty, and observance" (5.2.84-91) are closer to the demands 
made in marriage vows than the ridiculous actions he championed earlier. Silvius' character arc offers an example of the spectrum of love's joys and dangers for the two leads.

Not long after Rosalind overhears Silvius and his woes, she has an opportunity to meet Orlando. She has some warning that he is in the forest by finding his verses hanging on the trees. Though Thirwell contends that Rosalind is somewhat dismayed that Orlando is not so obvious a lover as Silvius, ${ }^{\text {lvi }}$ when Orlando is alone, his determination to plaster the forest with sonnets more than coveys the image of a literary obsessive. "Hang there, my verse, in witness of my love... O Rosalind! These trees shall be my books, / And in their barks my thoughts I'll character...Run, run, Orlando, carve on every tree / The fair, the chaste, and unexpressive she" (3.2.1-10). Orlando's verse as rather simplistic, as evidenced by Touchstone's comment "Truly the tree yields bad fruit" (3.2.113) and his subsequent litany of rhymes that follow Orlando's scansion. Like the verses that the lords in Love's Labour's Lost compose and critique, Orlando's verse is somewhat overwrought. Though Rosalind is the target of the verses, she critiques Orlando's technical prowess. "O, yes, I heard them all, and more too; for some of them had more feet than the verses would bear" (3.2.161-63). The faults she mentions indicate a lack of technical aptitude. Orlando, like the lords, is currently unable to move from the lofty ideals of poetry to the realities of life. It is a woman who delivers this life lesson in being a man, as the Princess and her ladies instruct the lords.

The exchanges and the erotic game that takes place between Rosalind and Orlando is one of the great joys of As You Like It. Thirwell encapsulates the nature of Rosalind's freedom in these scenes: “Rosalind's transvestite exile in Arden brings 
deliverance. Sporting doublet and hose, or jeans and trainers, unlaced from corset and farthingale, or prom gown and high heels, Rosalind's new erotic androgyny gives her the freedom to speak her mind" (75). Thirwell elaborates that the scenes with Orlando in the forest cemented the character in the minds of both male and female actors, including Adrian Lester and Rebecca Hall. Rosalind's Ganymede disguise allows her to interrogate Orlando's emotions in a way that would not have been possible as Rosalind. She is determined to play the interaction saucily and playfully chides him for his inadequate appearance as a lover.

Rosalind:

There is none of my uncle's marks upon you. He taught me how to know a man in love, in which cage of rushes I am sure you are not a prisoner.

Orlando:

What were his marks?

Rosalind:

A lean cheek, which you have not... a beard neglected, which you have not, but I pardon you for that, for simply your having in beard is a younger brother's revenue. Then your hose should be ungartered... and everything about you demonstrating a careless desolation. But you are no such man: you are rather point-device in your accoutrements, as loving yourself rather than seeming the lover of any other (3.2.357-371)

In other words, Orlando "should" be behaving and appear more like Silvius if he is to properly represent a lover. The image that Rosalind paints is of a typical effeminate lover, like Silvius and like Orlando as he was wildly running around the forest affixing sonnets to trees. Rosalind also emphasizes Orlando's youth; he can be forgiven for his lack of a disheveled beard, since his youth means that he has not yet come into a full beard. The phrase "a younger brother's revenue" recalls Orlando's dismay at the lack of material goods or education he has received from Oliver, which leaves him in the position of being unable to fully reach a man's estate. Rosalind's quip at Orlando being in love with himself, that his careful appearance is a mark of vanity, stings him. "Fair youth, I would I 
could make thee believe I love" (372-73). Rosalind follows with a woeful take similar in tone to a conduct book, perhaps thinking of Silvius and his ridiculous actions. "Love is merely a madness, and, I tell you, deserves as well a dark house and a whip as madmen do; and the reason that they are not so punished and cured is that the lunacy is so ordinary that the whippers are in love too" (386-390). Beyond the idea that love is both problematic in its effeminate extremes and the most ordinary madness of all, which is central to this study, Rosalind cunningly uses this argument as a pretext to "cure" Orlando as she has allegedly cured another: "He was to imagine me his love, his mistress; and I set him every day to woo me. At which time would I, being but a moonish youth, grieve, be effeminate, changeable, longing and liking, proud... as boys and women are for the most part cattle of this color" (392-9). Rosalind deliberately positions her performance as effeminate, underscoring for Orlando that she is male and therefore pretending to be a woman would be effeminate. This is also a metatheatrical moment for Elizabethan audiences, who know that the actor speaking these lines is in fact a boy impersonating an adult woman. In addition, Rosalind gestures at the supposed similarity of women and boys, which neatly explains why Ganymede will be able to effectively play Rosalind and reinforces the connection of young manhood with effeminacy.

In their subsequent scenes in the Forest of Arden, Orlando phases out of the effeminacy that his youth and lack of education have led him to and into a more mature masculinity. As Kathryn Moncrief ${ }^{\text {lvii }}$ argues that female tutelage is at the heart of Love's Labour's Lost, Orlando receives his tutelage from Rosalind. He is instructed in the modes of proper courtship and when he has absorbed these lessons, Rosalind rewards him with a marriage ceremony. 
Rosalind: Come, sister, you shall be the priest and marry us. Give me your hand,

Orlando. What do you say, sister?

Orlando: Pray thee marry us.

Celia: I cannot say the words.

Rosalind: You must begin, "Will you, Orlando"

Celia: Go too. Will you, Orlando, have to wife this Rosalind?

Orlando: I will.

Rosalind: Ay, but when?

Orlando: Why now, as fast as she can marry us.

Rosalind: Then you must say, "I take thee Rosalind, for wife." (4.1.115-126)

As has often been noted in discussions of this play, this "pretend" marriage could be considered legally binding as the two exchange vows in front of a witness. ${ }^{1 v i i i}$ Though this sort of marriage, per verba de praesenti, was scorned by the clergy, it did take place in the early modern era. Orlando's transformation involves painful subjugation in the same way as Berowne and the lords'. Rosalind does not let him off lightly for slights such as lack of punctuality and she is brutally honest with him about the realities of marriage. "I will be more jealous of thee than a Barbary cock pigeon over his hen...I will weep for nothing, like Diana in the fountain" (139-40). By listening to her instruction, Orlando undergoes a necessary process of effeminization, as it alters his former effeminate modes of behavior.

\section{Love's Labour's Lost in Performance}

Love's Labour's Lost has for centuries been one of Shakespeare's less performed comedies. However, in the twenty-first century, Love's Labour's Lost is being staged far more frequently. Filming the play is another matter, however. In 2000, famed actordirector Kenneth Branagh chose Love's Labour's Lost as the text for his fourth Shakespeare film. His previous outing, Hamlet, won critical and audience approval and 
was the first uncut filmed version of the play. His Love's Labour's Lost, however, takes an opposite approach. Branagh cut almost two thirds of Shakespeare's dialogue in favor of musical numbers. Branagh's film was critically panned; though Janice Wardle makes a case for viewing the film as pastiche, ${ }^{\text {lix }}$ it is debatable whether Love's Labour's Lost works for such an approach.

The main issues with Branagh's film for the purposes of this discussion lie in its presentation of manhood and its treatment of the ending. Its version of the comedic Russian scene is particularly egregious. Rather than having the men subject themselves to humiliation, they arrive in shirtsleeves and masks to dance an erotic tango with the women. Not only does this choice deprive the viewer of one of the comic highlights of the play, it makes the women's later assertions that they believed the men were jesting utterly baffling. Rather than men debasing themselves for love, as the text demonstrates, Branagh's lords enjoy a passionate dance with eager women. This choice also undermines the ending. In Branagh's rendition, it is a foregone conclusion that the men will end up with the women once the war is over. The women are presented as infatuated with the men before they have even appeared on screen together as they discuss the virtues of the respective lords on a boat ride with romantic mood lighting. The vows that the men undertake at the end of the play are more of a temporary inconvenience than a serious consequence. Branagh even finishes the film with a quick montage in which everyone survives the war and happily reunites on Victory Day. This ending is completely antithetical to the original. Without the effeminacy of the Russian episode, the men's humiliation and subjugation for love is lost and even the play's title is nonsensical. The men's labors have not been lost; to the contrary, they have been rewarded. 
The Royal Shakespeare Company mounted a production in Stratford in 2014 that transferred to London in 2016-2017 that was a critical and commercial success. Unlike Branagh's version, this production is focused. It sets the play in a very specific time and place: August 1914 at Charlecote Park, Warwickshire. The house is one that Shakespeare himself likely would have been familiar with. The setting also aids the portrayal of masculinity; the lords are viewed through the lens of immature pre-war British masculinity. In a sublime nod to Brideshead Revisited, Tunji Kasim's youthful Dumaine carries a teddy bear in one scene. Sam Alexander's Navarre is positioned as inexperienced next to the confident stateswoman of Leah Whittaker's princess, reinforcing the effeminacy in the text. Edward Bennett gives a masterful performance as Berowne. His reasoning for the lords to break their vows is calculated to ensure that the audience both admires his audacity and finds him self-serving in his determination to cast aside the vow of celibacy. Act 5 is transformed into the production's second act, and the Russian episode is expanded. The lords enter the scene as objects of fun. Dressed in Russian military uniforms with bushy false beards and hilariously terrible Russian accents, they sing to the Princess and her ladies. The humor of the moment is preserved, as is the fact that the men are subjecting themselves to humiliation for love. It also makes the women's declaration that they are being mocked understandable given the ludicrous nature of the lords' appearance.

The ambiguous resolution of the play is given emotional weight due to the 1914 setting. After the announcement that the Princess' father has died, the tone rapidly becomes somber. The play ends with Moth, Jacquenetta, and the ensemble singing Berowne's sonnet to Rosaline as Navarre and the lords enter in World War I uniforms. It 
created a powerful emotional impact. Berowne's vow to jest in a hospital took on the grim possibility that he may be a fellow wounded patient. The audience was left with the impression that the lords may not be able to keep their vows, not through unwillingness, but through death. The Royal Shakespeare Company created a reason for the abrupt tonal shift that occurs in the original text and formed an emotionally resonant conclusion using modern history and ensured that the audience could follow the portrayal of masculinity and effeminacy by grounding them in a setting familiar to British audiences.

The 2017 production of Love's Labour's Lost at the Blackfriars Playhouse took a very different approach to the ending of the play than the RSC production. Matthew Radford Davies, the guest director for the production, revealed that he has found that audiences do not respond well to the play without a note of optimism at the end. ${ }^{1 \mathrm{x}}$ This optimistic note leaves the audience with the impression that the marriages are a foregone conclusion. Though we do not see them celebrated on stage, it is easy to imagine a future in which these couples end up together. This seems to undercut the thread of cynicism that pervades the entire text.

Masculinity was presented in very humorous and thought-provoking ways. It was initially a surprise to see Christopher Seiler, the oldest member of the cast, playing the pageboy Moth, which is usually given to a very young actor. When Seiler came out in schoolboy shorts, walking on his knees, however, the audience laughed uproariously. It became very clear that Don Armado (Chris Johnston) was making a much older man pretend to be a youthful pageboy. He had to be kneeling so that his head would be low enough for Armado to pat. Given early modern attitudes to the status of manhood, this choice added a comically darker layer to Armado. He was dehumanizing an older person 
for his own benefit and amusement. The comedy came to a head when Moth plays the infant Hercules in the pageant on the Nine Worthies. Seiler was wheeled onstage in a large loincloth, looking urgently disgusted and uttering "Wah" in an increasingly bored voice. The humiliation of the Russian scene was still present as the men wore giant furs and hats making them resemble discount Vikings while the princess and her ladies looked on unimpressed.

The greatest innovation of the Blackfriars production lay in its music choices. All the actors sing and most play instruments, and they provide entertainment for the audience before the play and during intermission. As Paul Menzer argues, music is an essential component of the company's staging practices.

...music is the essential aesthetic essence at the Blackfriars...which frequently nests contemporary songs-broadly understood-into the drama of the sixteenth and seventeenth centuries. The actors appropriate tunes based upon thematic connections both witty and banal... This not only introduces one classic to another-John Ford, meet the Flamingoes-but elasticizes the meaning of the word 'classic' itself, democratizing the definition and elongating it as well. (Menzer 152-153)

I argue that through their musical choices, the Blackfriars company performs acts of presentist criticism. In yoking early modern and modern classics, they delve into what each play's thematic elements mean in the early modern era and in the present. As the audience took their places, the women performed a rendition of TLC's hit "No Scrubs." The resonance to Love's Labour's Lost was not lost on the audience. TLC's song concerns women expressing their displeasure with men who feel entitled to their time and attention without providing anything in return. The men of Love's Labour's Lost may believe that they are truly in love but for the objects of their affections, the attention is more like a jest than serious courtship. The Blackfriars choice of preshow music 
introduced one of the main themes of the play in a creative and modern way. Their intermission music continued with the 1990s hits. The women began by sing the Spice Girls" "Wanna Be" while the men retorted with *NSYNC's "Tearin' Up My Heart." The choice of both song and artist were thematically appropriate in both cases. What is "Wanna Be" but a list of demands telling men what they need to do to win the women's affection? The song provides a clever foreshadowing of what will happen in the final scene in the play. In addition, the Spice Girls were associated with the term "Girl Power," reinforcing the large amount of power that the French princess and her ladies have over the men. "Tearin' Up My Heart" meanwhile, is a catchy, somewhat melodramatic ode. *NSYNC was a hugely popular boy band. The term "boy band" is fascinating because though the singers were older than the term implies, often in their twenties, they were always referred to as such. Bands such as *NSYNC were often derided by men for their huge scores of female fans and their alleged lack of manliness in their singing and dancing. By singing a hit from this band, the men of the Blackfriars put the characters of the play into the role of a boy band, performing whatever it takes to attract the attention of women, even if their actions seem less than manly. Through musical selection, the performance of Love's Labour's Lost was able to explain the discourse of effeminacy present in the play by connecting it with an era that modern day audiences are more familiar with.

\section{As You Like It in Performance}

As You Like It has a long and rich performance history. For the purposes of

discussing masculinity and effeminacy, I will review three productions from the $20^{\text {th }}$ and 
$21^{\text {st }}$ century. Theater company Cheek by Jowl's 1991 production of As You Like It, revived in 1995, returned to an all-male cast to explore the gender dynamics and homoeroticism of the play. Director Declan Donnellan revealed that he was excited by the possibility of an all-male cast but was uncertain exactly what the result would be; even keeping a list of standby female Rosalinds. ${ }^{\text {lxi }}$ Adrian Lester's Rosalind uses the role of Ganymede as a chance to say what she really believes. Costuming for the female characters tends away from camp elements, with both Rosalind and Celia in solid colored dresses, simple jewelry, and very little makeup. Despite this, reviewer Yu Jin Ko found fault with the emotionalism of the actors. "... a streak of emotionalism ran throughout the production-as though that would automatically add a dimension of psychological realismwhich more often than not marred the delicate humor and poignancy of the play" (17). Lester's Rosalind certainly expresses a large variety of emotions, ${ }^{1 x i}$ but all are warranted in context; especially given Rosalind/Ganymede's mercurial temper in the forest scenes with Orlando. What Ko seemingly objects to is the association of emotionalism with camp. Ko is also quite determined to skim over the homoerotic elements inherent in an all-male production. "It should be noted, however, that the audience responded with uproarious approval. This response had much to do, I believe, with the sense that something very racy was being staged. And racy it was indeed. Because attention was never (nor could be) fully deflected from the condition of crossdressed playing, a continual homoerotic tension pervaded the play, finally erupting in full when Adrian Lester's Rosalind and Scott Handy's Orlando engaged in a long, steamy kiss in the final scene." (ibid) In associating a kiss between male-bodied actors as racy and steamy, Ko plays into the anti-theatricalist panic at portrayals of romance on stage. Prynne, Gosson, 
et al. were all absolutely terrified that racy things were being staged. Ko attempts to downplay some of the homoeroticism by insisting that the production, and the Shakespeare comedy it owes its existence to, was more about love and sexuality in general than specifically homo or heterosexual. James C. Bulman takes a different tack in a 2004 retrospective on the play, noting that the choice of an all-male cast today becomes political in a way that it would not have been for Shakespeare. Therefore, if a director does not stage such a production to privilege homoerotic and gender-bending elements of the text, then what is the aim?

In 2009, director Thea Sharrock utilized the stage of the Globe Theatre to present a very Elizabethan-style As You Like It. Orlando's immaturity was initially presented for comedic value as Jack Laskey wrestled with and finally sat on top of a whining Oliver (Jamie Parker), much to the delight of audience members. Though it at first seemed a bit of meaningless comedy, the episode highlighted Orlando's desperation with his mistreatment as well as his ignorance of how to handle the situation as an educated aristocrat would. Laskey has a natural skill with physical comedy and exaggerated facial expressions, which he makes full use of when he is unable to speak to Rosalind (Naomi Frederick). Orlando's gaping fish expressions in these moments illustrates his tendency toward effeminate behavior in a way that makes clearer for a modern audience what would have been obvious for an Elizabethan one. The production uses Elizabethan costuming, with Ganymede and Orlando dressed almost identically. In the forest scenes, they provide mirror images of each other, in a clever nod to the gender of the boy actor in the original performances in As You Like It, Short of using an all-male cast, Sharrock endeavors to instruct the audience in what an Elizabethan play would have looked and 
sounded like. This includes the traditional jig at the end of the play, and the full text of Rosalind's epilogue. The epilogue is often difficult to stage and can ring flat because the cross-gender casting is not usually present. Naomi Frederick gestured at it by lifting her dress to reveal her breeches on the line "If I were a woman..."

Shakespeare and Company in Lenox, Massachusetts presented an outdoor production of As You Like It in summer 2018. The production used costuming to effectively convey differences in rank. Orlando's (Deaon Griffin-Pressley) lament about his mistreatment that begins the play was highlighted by his simple undershirt, suspenders, and trousers while his brother Oliver (Thomas Brazzle) wore a three-piece suit and stylish hat. This visual contrast enabled the audience to readily sympathize with Orlando and recognize that he is not being treated according to his rank. Director Allyn Burrows made use of a 1920s setting to convey changes in gender roles, which narrowed the gap between Rosalind and Ganymede and presented more androgynous relationships. In a similar spirit of gender-bending, the genders of Touchstone and Audrey were inverted. Touchstone (MaConnia Chesser) was a vibrant woman of color who dove into the character's sexuality while Audrey became Aubrey (Thomas Brazzle), a shirtless forest dweller in overalls. The sexual chemistry was evident in their scenes together, and the gender inversions forced the audience to consider how we interpret relationships that are founded on lust, a woman with strong sexual appetites, and a man whose sole function is as an object of desire. ${ }^{\text {Ixii }}$ In the text, Touchstone's determination to marry Audrey is characterized by a lack of judgment; which flouts the advice given in conduct books that courtiers were meant to read. Touchstone's courtier persona begins to unravel into an effeminate man while in the forest of Arden. Orlando, however, undergoes the 
opposite transformation. In the stiff and formal world of Duke Frederick's court, he is painfully awkward, unable to respond in any way to Rosalind (Aimee Doherty). Under Ganymede's tutelage, he learns the lessons of manhood that his brother has denied him. Through choices in costume, blocking, and casting, these three productions perform their own discourses on masculinity and effeminacy.

\section{Conclusion}

Performance remains an essential framework for interpreting the comedies and their discussions of effeminacy. As my analysis of performance demonstrates, the Russian scene in Love's Labour's Lost acquires new meaning when viewed as opposed to read. A modern reader cannot fully absorb the level of humiliation and subjugation that the male characters go through for the sake of love through a reading of the text alone. A skilled director, however, can enable the audience to visually recognize what is taking place during the scene. The Russian scene is a particularly apt example, because though the women are clearly teasing the men, the male lords' disguises and song does not fully translate on the page. When the men are put in ridiculous fake beards and Russian army uniforms, complete with a bad Russian dance, the picture becomes complete. Performance works on the minds of the audience to convey themes through auditory and visual means that the page cannot provide. As You Like It also offers a clearer picture for the audience member because watching Rosalind become Ganymede is a vastly different experience on stage. In addition, Orlando and Silvius' lovelorn histrionics, glossed as effeminate behavior, acquire new humor through an actor's use of his voice and body language. Shakespearean comedy provides a fertile ground for discussions of the 
effeminacy of love, and it is through performance that those discussions become most fruitful. 


\section{Conclusion}

This study responds to a gap in the literature surrounding effeminacy. In this dissertation, I have argued that effeminacy takes on many definitions, and that its presence holds different meanings. I began with the image of the skipping king, and from there I have expanded and complicated the meanings of effeminacy in nine early modern texts.

In prose works, such as the conduct books and Sidney's Arcadia, effeminacy operates as a marker that something is going wrong in the lengthy process of masculine development and maturity. Furthermore, while effeminacy must be guarded against vigilantly, the mundane experiences of falling in love and surrendering to ungovernable emotions suggests that periodic effeminacy is almost inevitable. While Pyrocles and Musidorus are aware of the standards of conduct that their rank demands of them, they are unable to resist the tempest of adolescent love, which leads them to effeminate and questionable choices. Sidney skirts the boundaries of severe consequences for their behavior; the drama of the trial scene leads the reader to believe that the princes are headed for a death sentence. The sudden happy ending, however, undercuts the stringent warning. For Sidney, the journey is less important than the end point; and what matters is the formation of a mature, masculine courtier.

In the Roman plays, Sejanus and Antony and Cleopatra, Jonson and Shakespeare mobilize their classical sources to create portraits of effeminacy that will resonate as warnings to an early modern audience. Jonson's portrayal of an emperor giving up the cares of state for illicit liaisons, as I have discussed, felt too close to home for the Privy 
Council. Meanwhile, his Sejanus, for all his scheming and astute political awareness, begins his downfall through a massive lack of judgment in seeking a marriage partner above his rank. Sejanus' failure to interpret his place in Rome's strict hierarchical society marks him as just as effeminate as Tiberius to a Renaissance mind. Antony follows the more common definition of effeminacy; he is completely led by a woman. He subjugates himself so much to Cleopatra that he is no longer "Rome" but a servant of "Egypt." His manhood is questioned as Cleopatra robs him of his sword. It is only in death that he is refigured as a majestic emperor, again by Cleopatra; even in death, he requires a woman to help him regain his standing. These powerful Romans all (though Tiberius' fall is yet to come) suffer harsh consequences for their brand of effeminacy, and as the performance history of Antony and Cleopatra indicates, effeminacy is sometimes difficult for audience members to digest today.

The skipping king makes his appearance in Richard II, a text which shares an effeminate king with Edward II. In these presentations of medieval kings, effeminacy is presented as a marker of serious political instability with a realm in chaos. Edward is performing effeminacy with his obsessive devotion to one man, and his insistence of shaping Gaveston as his equal. Rather than a minion, Edward wants a male consort, and that wish is unacceptable to those who surround him. Richard, the skipping king, surrounds himself with flatterers who corrupt him with sinful behavior. His frequent want of judgment and prudence, along with an inability to control his emotions, lead directly to his cousin Bolingbroke's usurpation of the throne. The effeminacy of Edward and Richard is so stark that years later King Henry IV is sternly lecturing his son to avoid 
their example. England cannot be a strong England with a skipping king, or an effeminate prince.

Finally, in Shakespeare's comedies, As You Like It and Love's Labour's Lost, the presentation of effeminacy takes a lighter tone. Through male subjugation and humiliation, which are effeminate processes, the men transition into adult male lovers. Effeminacy is a messy stepping-stone on the path to maturity. Wild actions, like the Russian masque, and all the fantastical actions that an adult Corin has forgotten, may be risible, but they are not necessarily indicative of a permanent effeminacy. While youthful love may have the markers of effeminacy, such as excessive emotions and a determination to write bad poetry, this is merely a phase. Orlando learns from Rosalind how to be both a man and lover, as well as what the commitment of marriage means. Berowne and the lords are given a lesson in how to take courtship seriously and the value of time and maturity. In the comedies, far from the instigators of effeminacy that antitheatrical writers feared, women are the gatekeepers and the instructors of adult masculinity.

I envision further developments for the study of effeminacy and its presentation in modern productions. I am especially interested in researching productions of nonShakespearean texts for their depictions of masculinity and effeminacy. Since the critical prejudices and homophobia were so shocking to me in my research, I would like to devote more attention to this topic. With critics harping on Edward's "queenly" attitude and the pervasive use of the word "buggery," further study in how modern theater critics interpret and dismiss queer choices would be valuable. 
Preparing this dissertation has made me more aware of its relevance to the fields of theatre, history, and gender studies as well as literature. In tracing the concept of effeminacy from Sidney to Shakespeare, I have discovered a wealth of meanings and avenues for exploration. My initial response of curiosity and wonder to the phrase "the skipping king," spat with venom on a Stratford stage, has proven to be well founded and has led to a fruitful study of effeminacy and masculinity in early modern drama. 


\section{Endnotes}

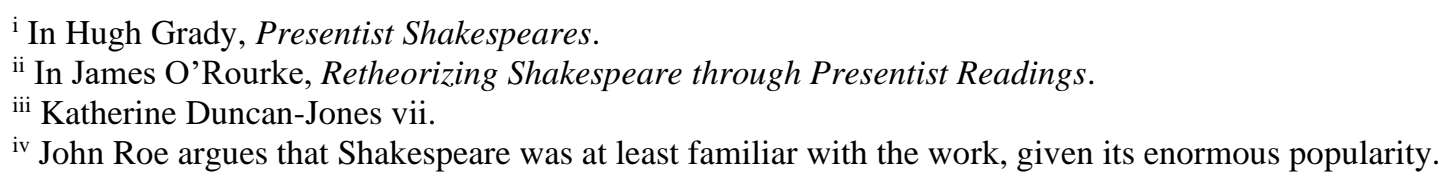
“Baldassare Castiglione's Il Libro del Cortegiano (or The Book of the Courtier) was easily available, having been translated into English by Sir Thomas Hoby and published in 1561; there were three subsequent editions during Elizabeth's reign, in 1577, 1588, and 1603" (Roe 39).

${ }^{v}$ Ian Moulton cites a trend in Italian literature in linking virtue with masculinity. Machiavelli focuses on the masculine principle of virtu (individual will) (124).

${ }^{v i}$ Moulton asserts, following other scholars, that Hoby was a skilled and accurate translator of the Italian (134).

vii All quotations from The Courtier are taken from Hoby's translation, unless otherwise noted.

viii The Oxford English Dictionary cites the anonymous Pearl as an example of the earlier usage but its more common meaning was also present in Chaucer's "Nun's Priest's Tale" (OED online).

${ }^{i x}$ For examples of the dynamics of childhood in Shakespeare, see The Winter's Tale. The young prince Mamilius spends his time with his mother and his nurse. When Hermione is suspected of adultery, he is immediately removed from her care. Meanwhile, Leontes imagines himself as a child, before he was given masculine clothing.

${ }^{x}$ MacFaul 17.

xi Ibid. MacFaul mentions Aristotle's Nicomachean Ethics and Cicero's De Amicitia in his analysis..

xii See page 16 of Arcadia.

xiii See Aristotle, Nicomachean Ethics.

xiv Katherine Duncan-Jones 370.

${ }^{x v}$ Brzozowska 194.

${ }^{x v i}$ Randall Bush interrogates the idea of prudence in readings of The Prince, an oft cited manual for political hopefuls. Bush establishes the idea that prudence was almost unquestioned as a necessary virtue for men, particularly those in the political sphere as he provides an intervention in reading the text imprudently. Randall Bush, "The Prince Against Prudence: On Textuality, Reading, and Politics in Political Theory." Philosophy and Rhetoric 48.3 (2015), 241-265.

xvii Brzozowska 192.

xviii Ayers 89.

xix Ayers 112.

${ }^{\mathrm{xx}}$ As discussed in Walters 31, adolescent males and male slaves of any age were not referred to by the term viri.

xxi Walters 30.

xxii Christopher 107.

xxiii Sejanus 3.623 .

xxiv Antony and Cleopatra, Norton Critical Edition, ed. Ania Loomba, 261. This quotation is excerpted from her book Shakespeare, Race and Colonialism, Oxford University Press, 2002.

${ }^{x x v}$ Oxford English Dictionary Online. 3 July 2017. This definition dates to 1386, with its first appearance in Chaucer's Wife of Bath's Prologue.

xxvi Plutarch 296.

xxvii Antony and Cleopatra 5.2.216.

xxviii Antony and Cleopatra 4.14.30.

${ }^{x x i x}$ I viewed this production through the Shakespeare Birthplace Trust. Call Number

RSC/TS/2/2/2005/SEJ1.

xxx Sejanus 4.404.

xxxi Christopher 115.

xxxii Michael B. Young, King James and the History of Homosexuality, 43.

xxxiii Michael Billington The Guardian. 
xxxiv I viewed this production through the National Theatre Archive. Call Number RNT/SO/2/2/61.

${ }^{x x x v}$ Anthony Fletcher, Gender, Sex and Subordination in England 1500-1800, 139.

xxxvi Talkback attended on October $26^{\text {th }}, 2019$.

xxxvii As noted by Ralph Alan Cohen in the program notes for the Blackfriars 2019 production of Antony

and Cleopatra.

xxxviii See Michael B. Young.

xxxix The word "favorite" itself has a long history of being used in relation to royalty. The Oxford English

Dictionary lists the second definition of favorite as "One who stands unduly high in the favour of a prince"

(OED online). The dictionary dates this usage to 1600, with Shakespeare's Much Ado About Nothing as the first example. Gaveston himself is also referred to as a favorite in J.R. Green's 1874 text Short History of the English People.

${ }^{\mathrm{xl}}$ See Lea Luecking Frost's work on Richard as a figure of lust in Elizabethan literature. Compare with Michael G. Cornelius' analysis on Edward II and same-sex love in Elizabethan literature.

xli Male characters who display an excess of emotion are also considered feminine. Consider Northumberland's rebuke to his son Hotspur in 1 Henry IV. "Why, what a wasp-stung and impatient fool art thou to break into this woman's mood" (2.1.235-6). See also the example of King Lear gendering his emotional outbursts as feminine.

xlii Katherine J. Lewis posits an alternate queer interpretation for King Richard as a virgin king. In the volume Gender and Holiness: Men, women and saints in late medieval Europe, Lewis' chapter on Richard identifies the king's devotion to Edward the Confessor and his relationship with his first wife Anne of Bohemia as possible reasons for remaining chaste.

xliii I viewed this production through the Shakespeare Birthplace Trust. Call Number

$\mathrm{RSC} / \mathrm{TS} / 2 / 2 / 1990 / \mathrm{ED} 21$

xliv I viewed this production through the National Theatre Archive. Call Number RNT/AE/1/1/245.

xlv Luecking Frost, 183.

xlvi Higginbotham 66.

xlvii Interview with Sarah Fallon conducted on March $16^{\text {th }}, 2018$.

xlviii Luecking Frost 183 and Christopher 115.

xlix See Harris O'Malley's “Ask Doctor NerdLove” website for an analysis of pick-up artistry and a corrective to its toxic operation.

${ }^{1}$ Smith Homosexual Desire 66.

${ }^{\text {li }}$ Melodie Garcia, "Don Adriano de Armado: a Spanish Character on the English Stage." Societe Francaise Shakespeare 32:2015 Nouvelles lectures de Love's Labour's Lost 1-11.

lii See also the shirt of Nessus, the poisoned garment which killed Hercules. Antony references this in 4.12 of Antony and Cleopatra.

liii Benedick condemns his friend Claudio in similar terms in Much Ado About Nothing.

liv See also Philip Sidney's Astrophil and Stella, "Thus great with child to speak and helpless in my throes" The poet inserts himself into the role of a laboring woman, utilizing a uniquely female experience to make sense of his own desperation at being unable to write as well as he wishes.

Iv See Jeffrey Masten, "Textual Deviance: Ganymede's Hand in As You Like It" 155.

lvi Angela Thirwell, Rosalind: Shakespeare's Immortal Heroine. Pegasus Books: New York, 2017. 71.

lvii Moncrief 86.

lviii For an example of how such a marriage takes place in drama, see John Webster's The Duchess of Malfi. The Duchess has been forbidden to marry by her brothers, so she has her maid Cariola hide while she makes vows of love to Antonio. Cariola then moves from her hiding place to witness the couple's vows.

lix Janice Wardle, "Interrogating Escapism: Rethinking Kenneth Branagh's Love's Labor's Lost."

Shakespeare Bulletin 31.3 (2013) 453-483.

Ix The talkback with Matthew Radford Davies and cast members took place on October 27, 2017.

Ixi Interview with Declan Donnellan recorded as part of a 1995 documentary for Open University on As You Like It narrated by Fiona Shaw. YouTube.

Ixii This production is not available in its entirety, but I was able to view scenes from it with the 1995 Open University documentary.

lxiii For a similar gender inversion, see Chris Hemsworth's character in the 2016 Ghostbusters reboot. Hemsworth leans into the role of the "bimbo" secretary, forcing the audience to consider why such roles seem natural for women but unacceptable for men. 


\section{Bibliography}

Altman, Joel. The Tudor Play of Mind. University of California Press, 1978.

Anderson, Thomas P. "Surpassing the King's Two Bodies: The Politics of Staging the Royal Effigy in Marlowe's Edward II.” Shakespeare Bulletin vol. 32, no. 4, 2014, pp. 585-611.

Anonymous. "Edward II review." Time Out London October 1990.

Barton, Anne. Ben Jonson, dramatist. Cambridge University Press, 1984.

Barker, Roberta. Early modern tragedy, gender and performance, 1984-2000, Palgrave Macmillan, 2007, EBSCOhost.

Bevington, David. “'Jack Hath Not Jill’: Failed Courtship in Lyly and Shakespeare.” John Lyly. Edited by Ruth Lunney, Ashgate Publishing Co., 2011, pp. 367-379. EBSCOhost.

Billing, Valerie. “The queer language of size in Love's Labour's Lost.” Queer Shakespeare: desire and sexuality, edited by Goran Stanivukovic and Vin Nardizzi, Bloomsbury Arden Shakespeare, 2017, pp. 107-122. EBSCOhost.

Branagh, Kenneth, director. Love's Labour's Lost. Miramax Films, 2000.

Bray, Alan. Homosexuality in Renaissance England, Columbia, 1995.

Brumble, H. David. "Personal, Paternal, and Kingly Control in Marlowe's Edward II." EIRC vol. 34, no. 1, 2008, pp. 56-70, EBSCOhost.

Brzozowska, Natalia. “The 'Roman Failures' of Jonson's Sejanus and Catiline Against 
the 'Roman Success' of William Shakespeare.” The Failed Text, edited by Jose Luis Martinez-Duenas Espejo and Rocio G. Sumillera, Cambridge Scholars Publishing, 2013.

Bulman, James C. "Bringing Cheek by Jowl's As You Like It Out of the Closet: The Politics of Queer Theater." Shakespeare Re-dressed: Cross-Gender Casting in Contemporary Performance, edited by James C. Bulman, Farleigh Dickinson University Press, 2008, pp. 79-95. EBSCOhost.

Burrows, Allyn, director. As You Like It. Shakespeare and Company, Lenox, MA, 2018. Bush, Randall. "The Prince Against Prudence: On Textuality, Reading, and Politics in Rhetorical Theory." Philosophy and Rhetoric vol. 48, no. 3 ,2015, pp. 241-265. EBSCOhost.

Callaghan, Dympna. "The terms of gender: 'gay' and 'feminist' Edward II." Feminist readings of early modern culture: emerging subjects, edited by Valerie Traub and Lindsay M. Kaplan, Cambridge University Press, 1996, pp. 275-301, EBSCOhost. Castiglione, Baldassare. The Book of the Courtier. Translated by Thomas Hoby. J.M. Dent and Sons, 1956.

Christopher, Brandon. “'Associate of our labours': Ben Jonson's Sejanus and the Limits of Master-Secretary Friendship.” The Ben Jonson Journal vol. 19, no. 1, 2012, pp. 105-126, EBSCOhost.

Cornelius, Michael G. Edward II and a Literature of Same-Sex Love: The Gay King in Fiction, 1590-1640. Lexington Books, 2016.

Craig, Martha. "Negotiating Sex: The Poetics of Feminization in Sidney's Arcadia." 
vol. 31, no. 1, 2005, pp. 89-106. EBSCOhost.

Crewe, Jonathan. "Disorderly Love: Sodomy Revisited in Marlowe's Edward II."

Criticism vol. 51, no. 3, 2009, pp. 385-399. JSTOR.

Davies, Matthew Radford, director. Love's Labour's Lost, Blackfriars Playhouse, Staunton, VA, 2017.

Deats, Sara Munson. “Shakespeare's Anamorphic Drama: A Survey of Antony and Cleopatra in Criticism." Antony and Cleopatra: New Critical Essays. Edited by Sara Munson Deats, Routledge, 2005, pp. 1-93, EBSCOhost.

De Jongh, Nicholas. “Antony and Cleopatra review.” Evening Standard, London, 21 October, 1998.

Doran, Gregory, director. Richard II, Royal Shakespeare Company, Stratford-uponAvon, 2012. DVD.

Doran, Gregory, director. Sejanus, Royal Shakespeare Company, 2005, Shakespeare Birthplace Trust, RSC/TS/2/2/2005/SEJ1.

Elyot, Thomas. The Book Named the Governour. (1531), J.M. Dent and Sons, 1966.

Fallon, Sarah. Personal interview. 15 March 2017.

Fallon, Sarah, director. Richard II, Blackfriars Playhouse, Staunton, VA, 2017.

Fletcher, Anthony. Gender, Sex, and Subordination in England 1500-1800. New Haven: Yale University Press, 1999. Print.

Garcia, Melodie. "Don Adriano de Armado: a Spanish Character on the English Stage." Societe Francaise Shakespeare vol. 32, 2015, Nouvelles lectures de Love's Labour's Lost pp. 1-11, EBSCOhost. 
Giles, David, director. Richard II. BBC Films, 1978. DVD.

Goffman, Erving. The Presentation of Self in Everyday Life. Doubleday, 1956.

Goldberg, Jonathan. Sodometries. Stanford University Press, 1992.

Goldfarb, Philip. "Jonson's Renaissance Romans: Classical Adaptation in Sejanus." Interdisciplinary Humanities vol. 31, no. 3, 2014, pp. 53-62, EBSCOhost.

Goold, Rupert, director. Richard II. BBC Films, 2012. DVD.

Grady, Hugh and Terence Hawkes. Presentist Shakespeares. Routledge, 2007. E-book.

Gray, Patrick. "Shakespeare versus Aristotle: Anagnorisis, Repentance, and Acknowledgment." Journal of Medieval and Early Modern Studies vol. 49, no. 1, 2019, pp. 85-111. Project Muse.

Greenblatt, Stephen. Shakespearean Negotiations. University of California Press, 1988.

Hallett, Judith P. and Marilyn B. Skinner. Roman Sexualities. Princeton University Press, 1997.

Harris, Jonathan Gil. “'Narcissus in Thy Face': Roman Desire and the Difference it Fakes in Antony and Cleopatra." Shakespeare Quarterly vol. 45, no. 4, 1994, 408-425, EBSCOhost.

Higginbotham, Derrick. "The Construction of a King: Waste, Effeminacy and Queerness in Shakespeare's Richard II." Shakespeare in Southern Africa vol. 26, 2014, pp. 59-73. Project Muse.

Hill-Gibbins, Joe, director. Edward II. Royal National Theatre, London, 2013, RNT Archive, RNT/AE/1/1/245. 
Jarman, Derek, director. Edward II. BBC Films, 1991.

James I, Basilikon Doron. Political Works of James I. Edited by Charles Howard McIlwain. Harvard University Press, 1918, pp. 3-52. www.stoics.com.

Jonson, Ben. Sejanus His Fall. Edited by Philip J. Ayers. Manchester University Press, 1999. Print.

Klett, Elizabeth. Cross-Gender Shakespeare and English National Identity. Palgrave Macmillan, 2009.

Ko, Yu Jin. "Straining Sexual Identity: Cheek by Jowl's All-Male As You Like It." Shakespeare Bulletin: The Journal of Early Modern Drama in Performance, vol. 13, no. 3, 1995, pp. 16-17. EBSCOhost.

Laqueur, Thomas. Making Sex, Harvard University Press, 1992.

Levine, Laura. Men in Women's Clothing: Anti-theatricality and Effeminization, 1579-1642, Cambridge University Press, 1994.

Lewis, Katherine J. "Becoming a virgin king: Richard II and Edward the Confessor." Gender and Holiness: Men, women and saints in late medieval Europe, Edited by Samantha J.E, Riches and Sarah Salih, Routledge, 2002.

Lewis, Peter. “Edward II review.” Daily Mail London, 30 April 1968.

Lochman, Daniel T. "Friendship's Passion: Love-Fellowship in Sidney's New Arcadia." Discourses and Representations of Friendship in Early Modern Europe, 15001700, Edited by Daniel Lochman and Lorna Hutson, Routledge, 2010. E-book. Luecking Frost, Lea. “"A Kyng That Ruled All By Lust”: Richard II in Elizabethan Literature." Literature Compass vol. 9, no. 2, 2012, pp. 183-198, EBSCOhost. 
Luscombe, Christopher, director. Love's Labour's Lost, Royal Shakespeare Company, London, 2017.

McFaul, Tom. “Friendship in Sidney’s Arcadias.” SEL vol. 49, no.1, 2009, pp. 17-33, EBSCOhost.

Marlowe, Christopher. Edward II, Edited by Martin Wiggins and Robert Lindsey, W. W. Norton, 1997.

Masten, Jeffrey, “Textual Deviance: Ganymede's Hand in As You Like It.” Field Work: Sites in Literary and Cultural Studies, Edited by Marjorie Garber et al, Routledge, 1996, pp. 153-163, EBSCOhost.

Matthias, Sean, director. Antony and Cleopatra, Royal National Theatre, London, 1998, RNT Archive, RNT/SO/2/2/61.

Menzer, Paul. Shakespeare in the Theatre: The American Shakespeare Center. Bloomsbury Arden Shakespeare, 2017.

Milligan, Gerry. "The Politics of Effeminacy in 'Il cortegiano."' Italica vol. 3, no. 4, 2006, pp. 345-366, JSTOR.

Moncrief, Kathryn M. ““'Teach us, sweet madam’: Masculinity, Femininity, and Gendered Instruction in Love's Labour's Lost." Performing Pedagogy in Early Modern England: Gender, Instruction, and Performance. Edited by Kathryn Read McPherson and Kathryn M. Moncrief, Routledge, 2011. E-book.

Moulton, Ian Frederick. "Castiglione: Love, Power, and Masculinity." The Poetics of Masculinity in Early Modern England and Spain. Edited by Gerry Milligan and Jane Tylus, Center for Reformation and Renaissance Studies, 2010 pp. 119-142. Murphy, Gerard, director. Edward II. Royal Shakespeare Company, London and 
Stratford, 1990, SBT, RSC/TS/2/2/1990/ED1.

Nightingale, Benedict. "Antony and Cleopatra review.” The Times of London, 21 October 1998.

Nightingale, Benedict. “Sejanus review.” The Times of London, 28 July 2005.

Orgel, Stephen. Impersonations. Cambridge University Press, 1996.

O'Rourke, James. Retheorizing Shakespeare Through Presentist Readings. Routledge, 2012. E-book.

Ott, Sharon, director. Antony and Cleopatra. Blackfriars Playhouse, Staunton, VA, 2019.

Payne, Alina, ed. Vision and Its Instruments: Art, Science, and Technology in Early Modern Europe. Pennsylvania State University Press, 2015.

Perry, Curtis. "The Politics of Access and Representations of the Sodomite King in Early Modern England” Renaissance Quarterly vol. 53, no. 4, 2000, pp. 1054-1083. EBSCOhost.

Plutarch, Makers of Rome. Edited by Ian Scott-Kilvert, Penguin Classics, 1965.

Quintilian, Institutio Oratoria. Translated by John Selby Watson. Quintilian's Institutes of Oratory. Lee Honeycutt, 8/9/11. Web.

Rackin, Phyllis. Stages of History: Shakespeare's English Chronicles. Cornell University Press, 1990.

Rasor, Katie. "The Neglected Tragedies: Reviving Sejanus and Catiline for Contemporary Audiences." Staging Ben: A Collection of Essays on the Theatricality of Jonson's Plays. Marshall Botvinick, ed. Cambridge, Cambridge Scholars Publishing, 2016. E-book.

Roe, John. "A Niggle of Doubt: Courtliness and Chastity in Shakespeare and 
Castiglione." Shakespeare and the Italian Renaissance: Appropriation, Transformation, Opposition. Edited by Michele Marrapodi, Ashgate Publishing Co., 2014, pp. 39-56.

Segal, Victoria. "Sejanus review.” Sunday Times, London, 31 July, 2005.

Shepard, Alexandra. Meanings of Manhood in Early Modern England. Oxford University Press, 2003.

Sidney, Philip. The Old Arcadia. Edited by Katherine Duncan-Jones, Oxford University Press, 2008.

Sinfield, Alan. Shakespeare, Authority, Sexuality. Routledge, 2006.

Shakespeare, William. The First Part of King Henry the Fourth. The Complete Pelican Shakespeare. Edited by Stephen Orgel and A.R. Braunmuller, Penguin, 2002. 1039-1085.

Shakespeare, William. Love's Labor's Lost. Ibid. 209-257.

Shakespeare, William. As You Like It. Ibid. 401-437.

Shakespeare, William. Richard II. Ibid. 959-999.

Shakespeare, William. Antony and Cleopatra. Edited by Ania Loomba, W.W. Norton and Company, 2011.

Shirley, Christopher. "Sodomy and Stage Directions in Christopher Marlowe's Edward(s) II." SEL Studies in English Literature 1500-1900 vol. 54, no. 2, 2014, pp. 279-296. Project Muse.

Smith, Bruce. Homosexual Desire in Shakespearean England. University of Chicago Press, 1991.

Smith, Bruce. Shakespeare and Masculinity. Oxford University Press, 2000. 
Starks, Lisa S. “'Immortal Longing': The Erotics of Death in Antony and Cleopatra." Antony and Cleopatra: New Critical Essays. Edited by Sara Munson Deats, Routledge, 2005, pp. 245-258.

Stone, James W. Crossing Gender in Shakespeare: Feminist Psychoanalysis and the Difference Within. Routledge, 2010.

Stump, Donald. "Reforming the Greek Tragic Hero: Narrative Trickery and Gender Reversal in Sidney's Old Arcadia." Teaching early modern English prose, edited by Susanna Brietz and Margaret W. Ferguson, Modern Language Association of America, 2010, pp.177-187, EBSCOhost.

Stymeist, David. "Status, Sodomy, and the Theater in Marlowe's Edward II." SEL Studies in English Literature 1500-1900 vol. 44, no. 2, 2004, pp. 233-253. EBSCOhost.

Tacitus, The Annals. Translated by J.C. Yardley. Oxford UP, 2008.

Taylor, Paul. “Antony and Cleopatra review.” Independent, London, 22 October 1998.

Taylor, Paul. "Sejanus review." Independent, London, 29 July 2005.

Thirwell, Angela. Rosalind: Shakespeare’s Immortal Heroine. Pegasus Books, 2017.

Traub, Valerie. Desire and Anxiety: Circulations of Sexuality in Shakespearean Drama. Routledge, 1992.

Walters, Jonathan. "Invading the Roman Body: Manliness and Impenetrability in Roman Thought.” Roman Sexualities. Edited by Judith P. Hallett and Marilyn B. Skinner, Princeton University Press, 1997, pp. 29-47. 
Wardle, Janice. “Interrogating Escapism: Rethinking Kenneth Branagh's Love's Labor's Lost." Shakespeare Bulletin vol. 31, no. 3, 2013, pp. 453-483.

Warner, Deborah, director. Richard II. Illuminations, 1997.

Warren, Jim, director. Antony and Cleopatra. Blackfriars Playhouse, Staunton, VA, 2015.

Witts, Preston. “Sejanus review." Stratford Herald, Stratford, 28 July 2005.

Whitworth, Stephen. "Sidney, Lacan, and the Perverse Phantasy of Pastoral." Shakespeare yearbook vol. 19, no. 19, 2010, pp 385-405, EBSCOhost.

Yoon, Ju ok. "Desire, Duty, and Poetics of Incompletion: Edmund Spenser's The Faerie Queene (Book 1) and Philip Sidney's The Old Arcadia." Shakespeare Review vol. 45, no. 4, pp. 619-640, EBSCOhost.

Young, Michael B. King James and the History of Homosexuality. Fonthill, 2016. 